Pacific Northwest

National Laboratory

Operated by Battelle for the

U.S. Department of Energy

\section{Goldschmidt Conference 2005: Field Trip Guide to the Columbia River Basalt Group}

\author{
B. S. Martin \\ H. L. Petcovic \\ S. P. Reidel
}

May 2005

\footnotetext{
Prepared for the U.S. Department of Energy
} under Contract DE-AC05-76RL01830 


\title{
DISCLAIMER
}

This report was prepared as an account of work sponsored by an agency of the United States Government. Reference herein to any specific commercial product, process, or service by trade name, trademark, manufacturer, or otherwise does not necessarily constitute or imply its endorsement, recommendation, or favoring by the United States Government or any agency thereof, or Battelle Memorial Institute.

\author{
PACIFIC NORTHWEST NATIONAL LABORATORY \\ operated by \\ BATTELLE \\ for the \\ UNITED STATES DEPARTMENT OF ENERGY \\ under Contract DE-AC05-76RL01830
}

\begin{abstract}
Printed in the United States of America
Available to DOE and DOE contractors from the

Office of Scientific and Technical Information, P.O. Box 62, Oak Ridge, TN 37831;

prices available from (615) 576-8401.

Available to the public from the National Technical Information Service,

U.S. Department of Commerce, 5285 Port Royal Rd., Springfield, VA 22161
\end{abstract}

This document was printed on recycled paper. 


\section{Goldschmidt Conference 2005: Field Trip Guide to the Columbia River Basalt Group}

B. S. Martin

H. L. Petcovic

S. P. Reidel

May 2005

Prepared for

the U.S. Department of Energy

under Contract DE-AC05-76RL01830

Pacific Northwest National Laboratory

Richland, Washington 99352 


\section{Summary}

This field trip guide was prepared for the 2005 Goldschmidt Conference held in Moscow, Idaho. The field trip guide provides a two day introduction to the features of the Columbia River Basalt Group in eastern Washington. 


\section{Contents}

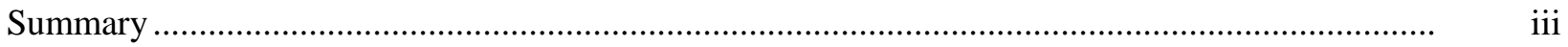

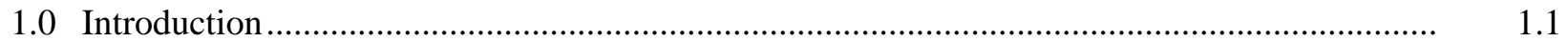

2.0 Stratigraphy and Structural Framework of the Columbia Plateau ........................................... 2.1

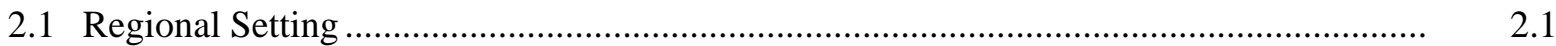

2.1.1 The Columbia Basin..........................................................................................

2.1.2 The Blue Mountains .............................................................................................

2.1.3 The Olympic-Wallowa Lineament ....................................................................... 2.3

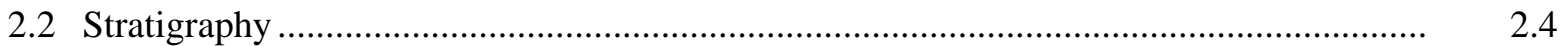

2.2.1 Stratigraphy Older Than the Columbia River Basalt Group .................................. 2.4

2.2.2 Stratigraphy Younger Than the Columbia River Basalt ....................................... 2.6

2.2.3 Stratigraphy of the Columbia River Basalt Group ................................................. 2.6

2.2.4 Stratigraphic Subdivisions of the Columbia River Basalt Group............................ 2.7

3.0 Major Internal Features of Columbia River Basalt Group Flows ….........................................

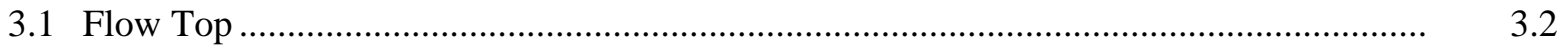

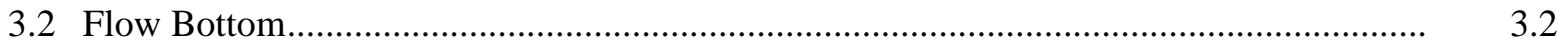

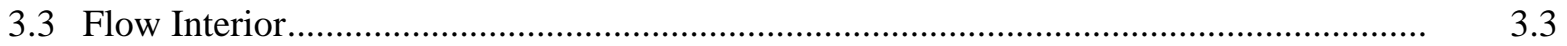

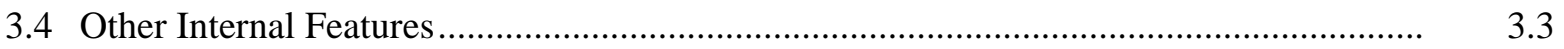

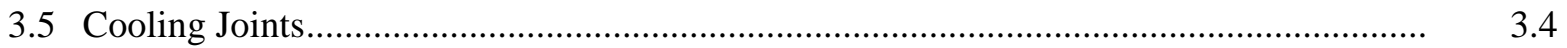

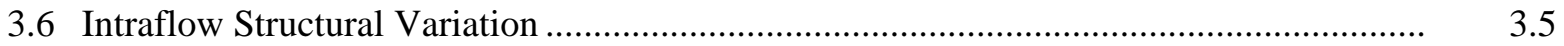

3.7 Identifying Columbia River Basalt Group Flows............................................................

4.0 Columbia River Basalt Group Dikes: The Chief Joseph Dike Swarm....................................

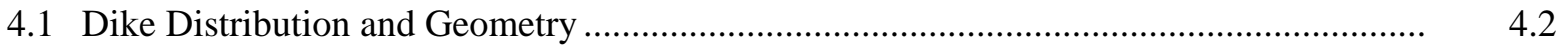

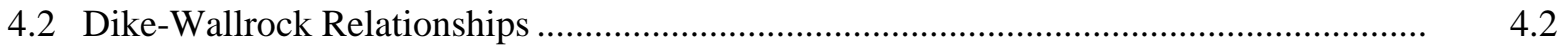

4.3 Correlation of Dikes with Flows …................................................................................

5.0 Columbia River Basalt Group Eruption and Emplacement Rates........................................... 5.1

5.1 The Roza Member Vent System ...............................................................................

5.2 Estimates of CRBG Eruption Rates from Dike-Wallrock Relationships .......................... 5.2

5.2.1 The Maxwell Lake Dike and Member of Wapshilla Ridge ................................... 5.2

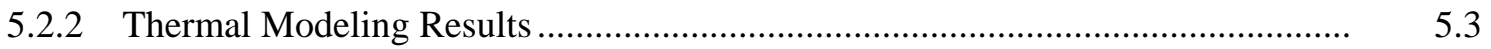

5.2.3 Implications for CRBG Flow Emplacement ........................................................ 5.3

5.3 General Conclusions for Emplacement of Columbia River Basalt Group Flows .............. 5.5 


\section{Figures}

1 Map Showing the Extent of the Columbia River Basalt Group and Main

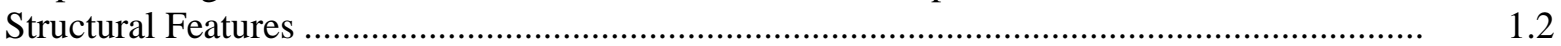

2 Setting and Extent of the Columbia River Basalt Group ....................................................... 2.2

3 Principal Structural Features of the Northern Part of the Columbia River Flood-

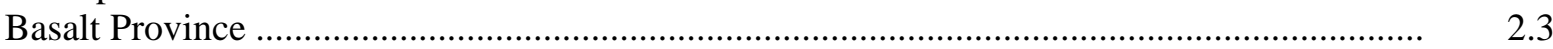

$4 \quad$ Nomenclature for the Columbia River Basalt Group ............................................................... 2.5

$5 \quad$ Volume of Columbia River Basalt Group Eruptions Over Time ............................................. 2.7

6 Geologic Map of the Columbia River Basalt Group ............................................................... 2.8

$7 \quad$ Thickness Map of the Columbia River Basalt Group …........................................................... 2.9

8 Major Basalt Flow Features of a Columbia River Basalt Group Lava Flow ............................

9 Histogram and a Cumulative Distribution Function for Cooling Joint Spacing for HighAngle Joints from an Exposure of the Rocky Coulee Flow of the Member of Sentinel

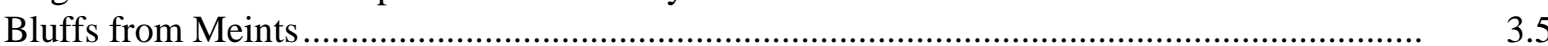

10 Areal Extent of Columbia River Basalt Group from Figure 1 ..............................................

11 Location for the Known Feeder Dikes and Vents for the Columbia River Basalt Group.......... $\quad 4.3$

12 Map Showing Route Followed by Guidebook....................................................................

\section{Table}

1 Estimates of Eruption Rates for Selected CRBG Flow Units 


\subsection{Introduction}

The Columbia River Basalt Group (CRBG) extends over approximately 200,000 km² of Washington, Oregon and Idaho (Figure 1). This area is commonly called the Columbia Plateau and includes the Columbia Basin to the north and the higher elevation Blue Mountains and lava plains to the south. Over 75 percent of the total erupted volume occurs in the northern part of the Columbia River flood basalt province, concentrated in the Columbia Basin and Blue Mountains Province of Washington, northern Oregon, and western Idaho. The oldest flows are found in southern Oregon extending as far north as the Washington, Oregon, Idaho common boundary, with the main eruptions and younger units occurring in the northern part of the province.

This field trip guide provides an introduction to the geologic features of the Columbia River Basalt Group and a description of the main features of the sites that will be visited as part of the Goldschmidt Conference Columbia River Basalt Group Field Trip. The introduction concentrates on the northern portion of the basalt province where the conference is held. 


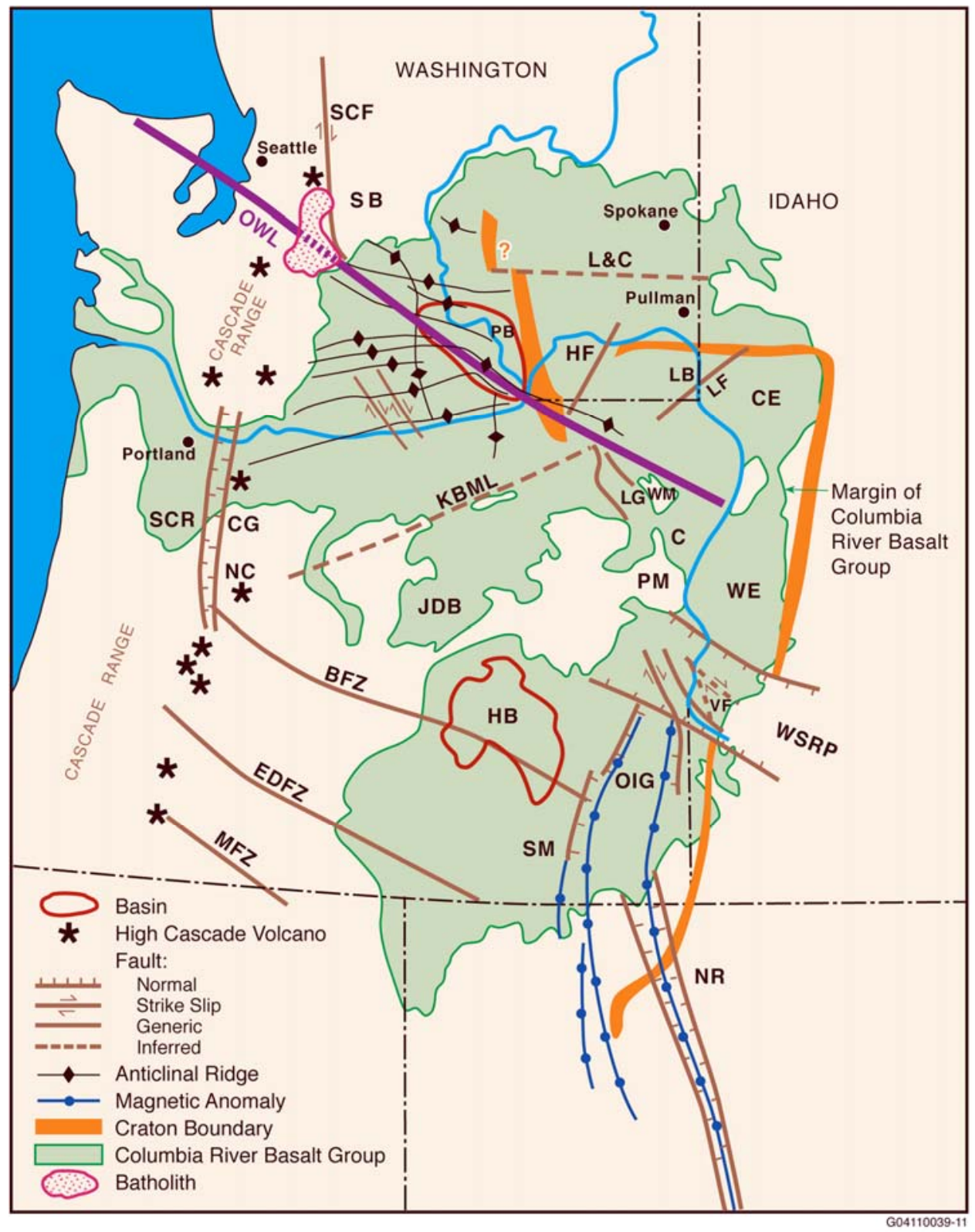

Figure 1. Map Showing the Extent of the Columbia River Basalt Group and Main Structural Features. OWL = Olympic-Wallowa lineament; LB = Lewiston basin; WW = Walla Walla; $\mathrm{C}=$ Cornucopia part of the Chief Joseph dike swarm; WSRP = western Snake River Plain; OIG = Oregon-Idaho graben; SM = Steens Mountains; NR = Nevada Rift zone; MF; BFZ = Brothers Fault zone; EDFZ = Eugene-Denio fault zone; MFZ = Modoc fault zone; WE = Weiser embayment; PM = Pedro Mountains; KBLM = Klamath-Blue Mountains linear (gravity); JDB = John Day basin; LG = LaGrange graben; HF = Hite fault; LF = Limekiln fault; NC = Newberry caldera; CG = Cascade graben; L\&C = Lewis and Clark line (gravity anomaly); SCF = Straight Creek fault; SB = Snoqualmie batholith; SCR = Southern Cascade Range; HB = Harney Basin. 


\subsection{Stratigraphy and Structural Framework of the Columbia Plateau}

\subsection{Regional Setting}

The general area of the Goldschmidt Conference Columbia River Basalt Group Field Trip is in the eastern part of the Columbia Basin and northern part of the Blue Mountains Province (Figure 2). Anticlines associated with the Blue Mountain and the Lewiston Basin form the main structural elements of the field trip area.

\subsubsection{The Columbia Basin}

The Columbia Basin is an intermontane basin between the Cascade Range and the Rocky Mountains that is filled with Cenozoic volcanic rocks and sediments. This basin forms the northern part of the Columbia Plateau physiographic province (Fenneman 1931) and the Columbia River flood-basalt province (Reidel and Hooper 1989). In the central and western parts of the Columbia Basin, the Columbia River Basalt Group overlies Tertiary continental sedimentary rocks that, in turn, overlie the crystalline basement. The basalt rocks are overlain by late Tertiary and Quaternary fluvial and glaciofluvial deposits (Campbell 1989; Reidel et al. 1989b; Smith et al. 1989; Department of Energy 1988). In the eastern part of the Columbia Basin, a thin ( $<100 \mathrm{~m}$ ) sedimentary unit separates the basalt and underlying crystalline basement and a thin $(<10 \mathrm{~m})$ veneer of eolian sediments overlies the basalt (Reidel et al. 1989b).

Beginning in the late 1950s and continuing through the 1980s, deep boreholes were drilled for both hydrocarbon exploration in the Columbia Basin and for various projects at the U.S. Department of Energy's Hanford Site. These boreholes provided detailed data on the Columbia River Basalt Group rocks and the underlying pre-basalt sediments (Reidel et al. 1994, 1982). The thickness of the basalt and the pre-basalt sediments was found to vary as a result of different tectonic environments. The western edge of the late Precambrian/early Paleozoic continental margin and Precambrian North American craton is shown in Figure 2. The stratigraphy on the craton consists of Columbia River Basalt Group rocks overlying crystalline basement; the crystalline basement is continental crustal rock typical of that which underlies much of the western North America. The stratigraphy west of the craton consists of 4-5 km of Columbia River Basalt Group rocks overlying greater than $6 \mathrm{~km}$ of Eocene and Oligocene sediments. This in turn overlies accreted terrains of Mesozoic age.

The Columbia Basin has two structural subdivisions or subprovinces: the Yakima Fold Belt and the Palouse Slope (Figure 3). The Yakima Fold Belt includes the western and central parts of the Columbia Basin and is a series of anticlinal ridges and synclinal valleys with northwest to northeast structural trends. The Palouse Slope is the eastern part of the basin and is the significantly less deformed subprovince with only a few faults and low amplitude, long wavelength folds on an otherwise gently westward dipping paleoslope (Swanson et al. 1980). The Yakima Fold belt overlies rock west of the craton and the Palouse Slope overlies the craton. 


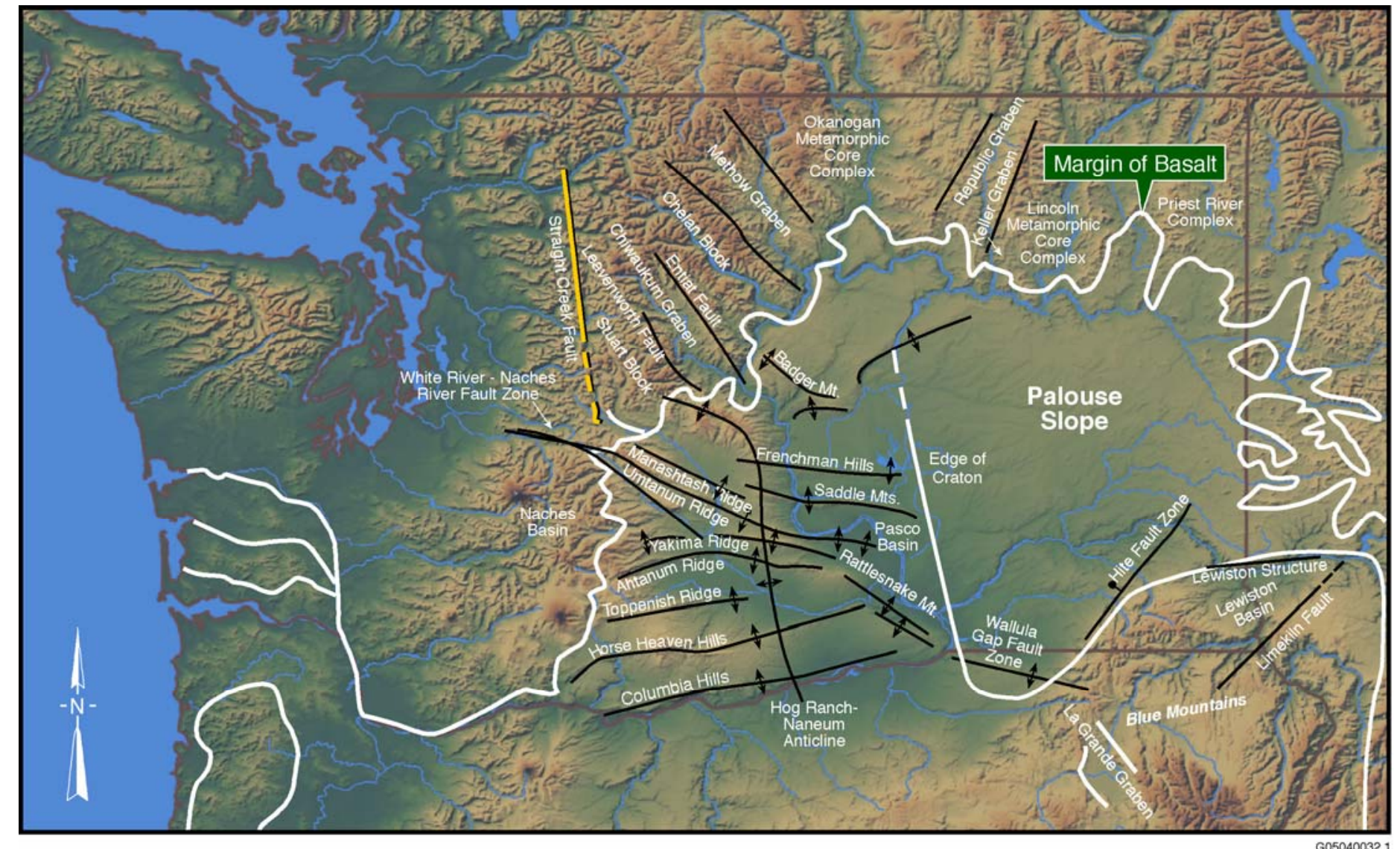

Figure 2. Setting and Extent of the Columbia River Basalt Group 


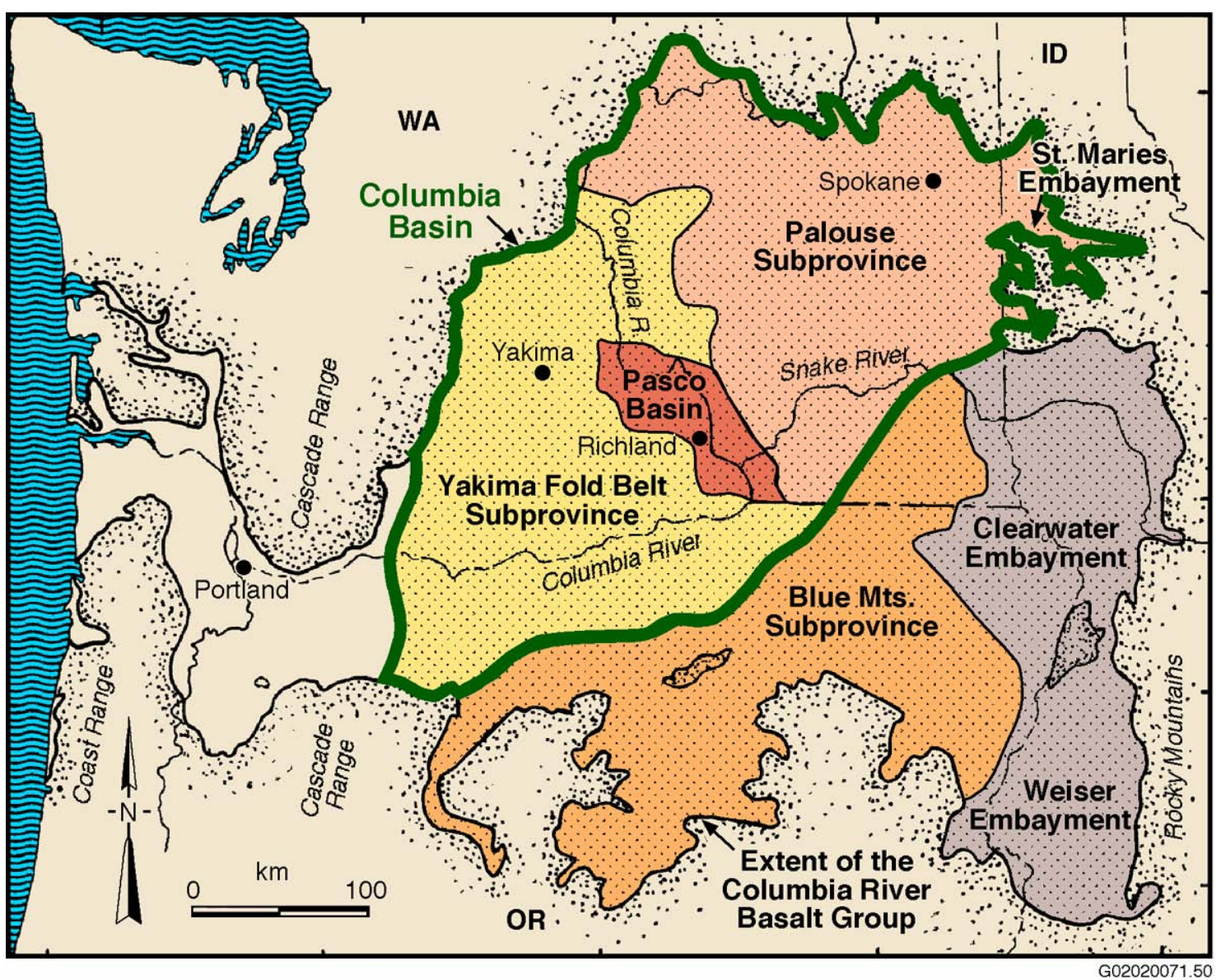

Figure 3. Principal Structural Features of the Northern Part of the Columbia River Flood-Basalt Province

\subsubsection{The Blue Mountains}

The Blue Mountains subprovince of the Columbia River flood-basalt province forms the southern boundary of the Columbia Basin. The Blue Mountains is a northeast-trending anticlinorium that extends $250 \mathrm{~km}$ from the Oregon Cascades to the eastern part of the Columbia Basin. It overlies the Mesozoic accreted terrain rock assemblages and Eocene and Oligocene volcaniclastic rocks. The Lewiston Basin is a fault-bounded basin or graben lying near the intersection of the Palouse and Blue Mountains subprovinces with the Clearwater Embayment.

\subsubsection{The Olympic-Wallowa Lineament}

The Olympic-Wallowa lineament (OWL) is a major topographic feature in Washington and Oregon that crosscuts the Columbia Basin (Raisz 1945; Figure 1). This feature parallels pre-basalt structural trends along the northwest margin of the Columbia Basin but it has not been linked to any individual structure (Campbell 1989; Reidel and Campbell 1989). Within the Yakima Fold Belt, the OWL includes 
a zone of Miocene and post-Miocene deformation along Manastash Ridge and apparent bending of Umtanum Ridge, Yakima Ridge, and Rattlesnake Ridge (Figures 1 and 2).

The portion of the OWL that crosses central Washington is called the Cle Elum-Wallula deformed zone (CLEW; Keinle et al. 1977). It is a 10-km-wide, moderately diffuse zone of anticlines that have a $\mathrm{N} 50^{\circ} \mathrm{W}$ orientation. As defined by Davis (1981), the central part consists of three structural parts: (1) a broad zone of deflected or anomalous fold and fault trends extending south from Cle Elum to Rattlesnake Mountain; (2) a narrow belt of topographically aligned domes and doubly plunging anticlines extending from Rattlesnake Mountain to Wallula Gap; and (3) the Wallula fault zone, extending from Wallula Gap to the Blue Mountains.

Northwest of the CRBG margin, numerous northwest- and north-trending faults and shear zones of the Straight Creek fault system lie subparallel to the OWL (Tabor et al. 1984). The Snoqualmie batholith intrudes these faults but is not cut by them, indicating that any possible movement along the OWL at the western margin of the Columbia Basin must be older than the batholith, 17-19.7 Ma (Frizzell et al. 1984).

The structural significance of the OWL has been called into question by two geophysical studies. Neither a seismic profiling survey by Jarchow (1991) nor a gravity survey by Saltus (1991) could find any obvious geophysical signature for the OWL below the CRBG.

\subsection{Stratigraphy}

The generalized stratigraphy of the Columbia River Basalt Group in the northern part of the province is summarized in Figure 4. The main rocks exposed are the Columbia River Basalt Group, intercalated sedimentary rocks of the Ellensburg Formation in Washington and Latah Formation in Idaho, and younger sedimentary rocks that include the Ringold Formation, Snipes Mountain conglomerate, Thorp gravels, Pleistocene cataclysmic flood deposits of the Hanford formation, and other localized strata.

\subsubsection{Stratigraphy Older Than the Columbia River Basalt Group}

Rocks older than the CRBG are only exposed along the margin of the Columbia Basin. Stratigraphy along the margin of the CRBG is complex and varies widely in both age and lithology (Campbell 1989). A series of sedimentary basins formed along the northwest margin in early Tertiary time (Tabor et al. 1984; Campbell 1989). Tectonic "blocks” or uplifts exposing pre-Tertiary rocks that have a northwesttrending structural grain now separate these basins.

Along the northeast and east margins of the Columbia Basin, the CRBG laps onto Paleozoic rocks and Precambrian metasedimentary rocks interspersed with younger crystalline rocks. These include: Proterozoic metasediments of the Windermere and Belt Supergroups, miogeosynclinal lower Paleozoic shallow marine rocks, rocks associated with the Kootenay Arc, and granitiods of the Idaho Batholith and other Jurassic and Cretaceous intrusions (Stoffel et al. 1991). The structural grain of these rocks is north to northeast. 


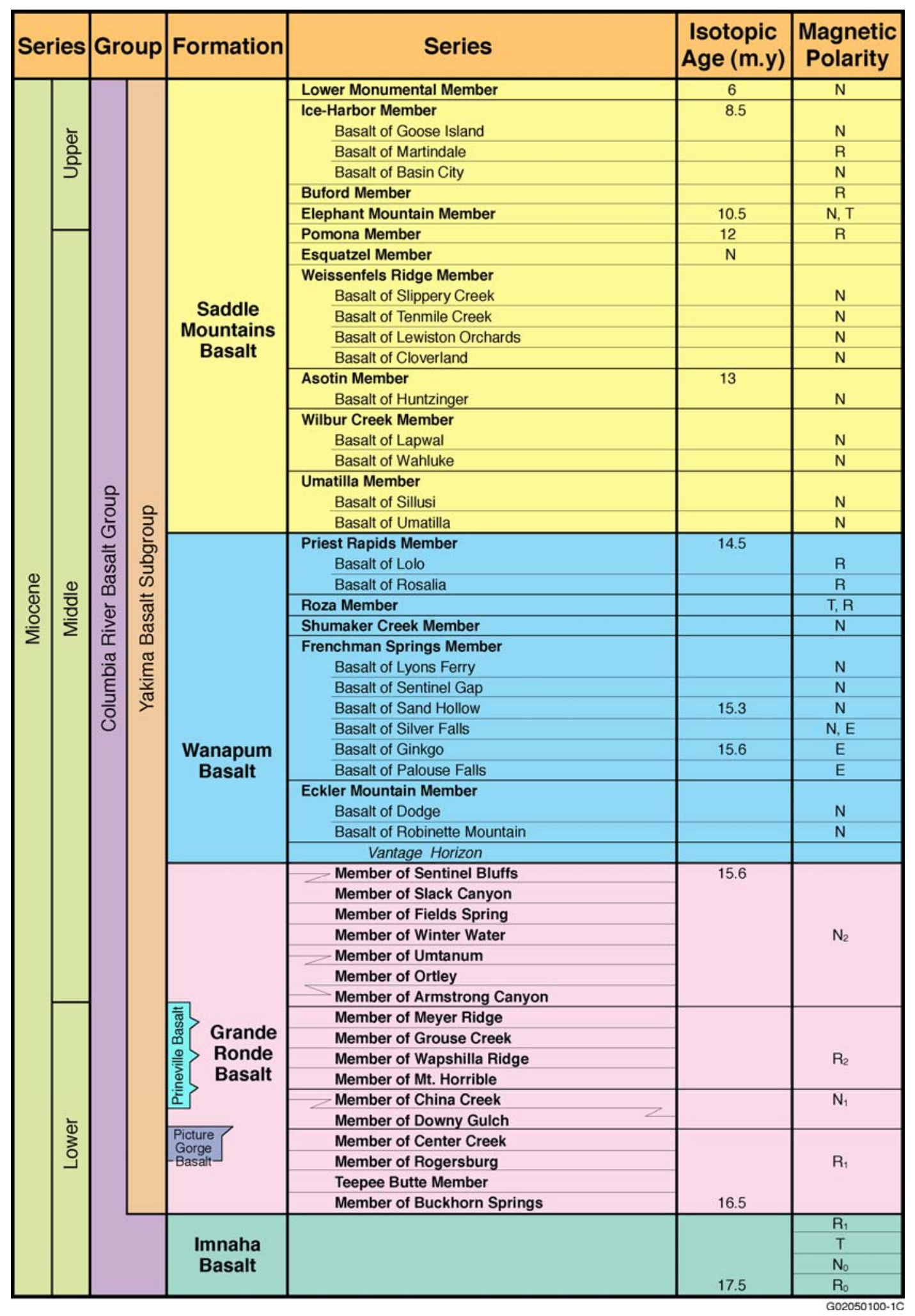

Figure 4. Nomenclature for the Columbia River Basalt Group 
To the south and southwest, lower to middle Tertiary volcanic rocks and related volcaniclastic rocks directly underlie the CRBG. The rocks include tuffs, lahars, and tuffaceous sedimentary rocks interbedded with rhyolite, andesite, and basalt flows and breccias; these are primarily assigned to the Clarno and John Day Formations. Older (Cretaceous-Permian) volcaniclastic sediments and metasediments of accreted intra-arc- and volcanic arc-origin are exposed along the southeast margin of the CRBG (Walker and MacLeod 1991).

\subsubsection{Stratigraphy Younger Than the Columbia River Basalt}

Most post-CRBG sediments are confined to the synclinal valleys of the Yakima Fold Belt and related basins, such as the Lewiston Basin, and reflect the structural development of the Columbia Basin (Fecht et al. 1987). The upper Miocene to middle Pliocene record of the Columbia River system including the Snake, Clearwater, and Salmon Rivers in the Columbia Basin is represented by the upper Ellensburg Formation, Latah Formation, Ringold Formation, and Snipes Mountain conglomerate. Except for local deposits, there is a hiatus in the stratigraphic record between the end of Ringold time (3.4 Ma) and the Pleistocene (1.6 Ma). Pleistocene to Recent sediments overlying the CRBG include: flood gravels and slackwater sediments of the Pleistocene glacial floods, terrace gravels of the Columbia, Snake and Yakima Rivers, and eolian deposits including the Palouse Formation in eastern Washington.

\subsubsection{Stratigraphy of the Columbia River Basalt Group}

Columbia River Basalt Group flows cover most of eastern Washington, northeast Oregon, and portions of western Idaho in the northern part of the flood-basalt province. Intercalated with and in some places overlying the CRBG are epiclastic and volcaniclastic sedimentary rocks of the Ellensburg Formation (Waters 1961; Swanson et al. 1979; Smith 1988) and fluvial deposits of the Latah Formation in Idaho. Most volcaniclastic material occurs in the western basin; in the central and eastern basin, epiclastic sediments of the ancestral Clearwater and Columbia Rivers form the dominant lithologies (Fecht et al. 1982, 1987).

The CRBG (Figure 4) consist of a thick sequence of well over 300 continental tholeiitic flood-basalt flows that were erupted over an 11 million year period from about 17 to $6 \mathrm{Ma}$ (Swanson et al. 1979). These flood-basalt flows cover an area over $200,000 \mathrm{~km}^{2}$ in Washington, Oregon, and western Idaho (Figure 1) and have a total estimated volume of more than 224,000 $\mathrm{km}^{3}$ (Hooper et al. 2002; Camp et al. 2003). Individual flows typically extend over many thousand square $\mathrm{km}$. The source for most of these flows was a series of north-northwest-trending linear fissure systems located in eastern Washington, northeastern Oregon, and western Idaho.

Although the eruption of CRBG flows spans an 11 million year period, the majority of the CRBG ( $>96$ volume percent) was erupted over a period of about 2.5 million years, from 17 to $14.5 \mathrm{Ma}$ (Swanson et al. 1979) (Figure 5). During this peak period of activity, many of the flows that were erupted were of extraordinary size, exceeding $1,000 \mathrm{~km}^{3}$ in volume and traveled many hundreds of kilometers from their vent system. 


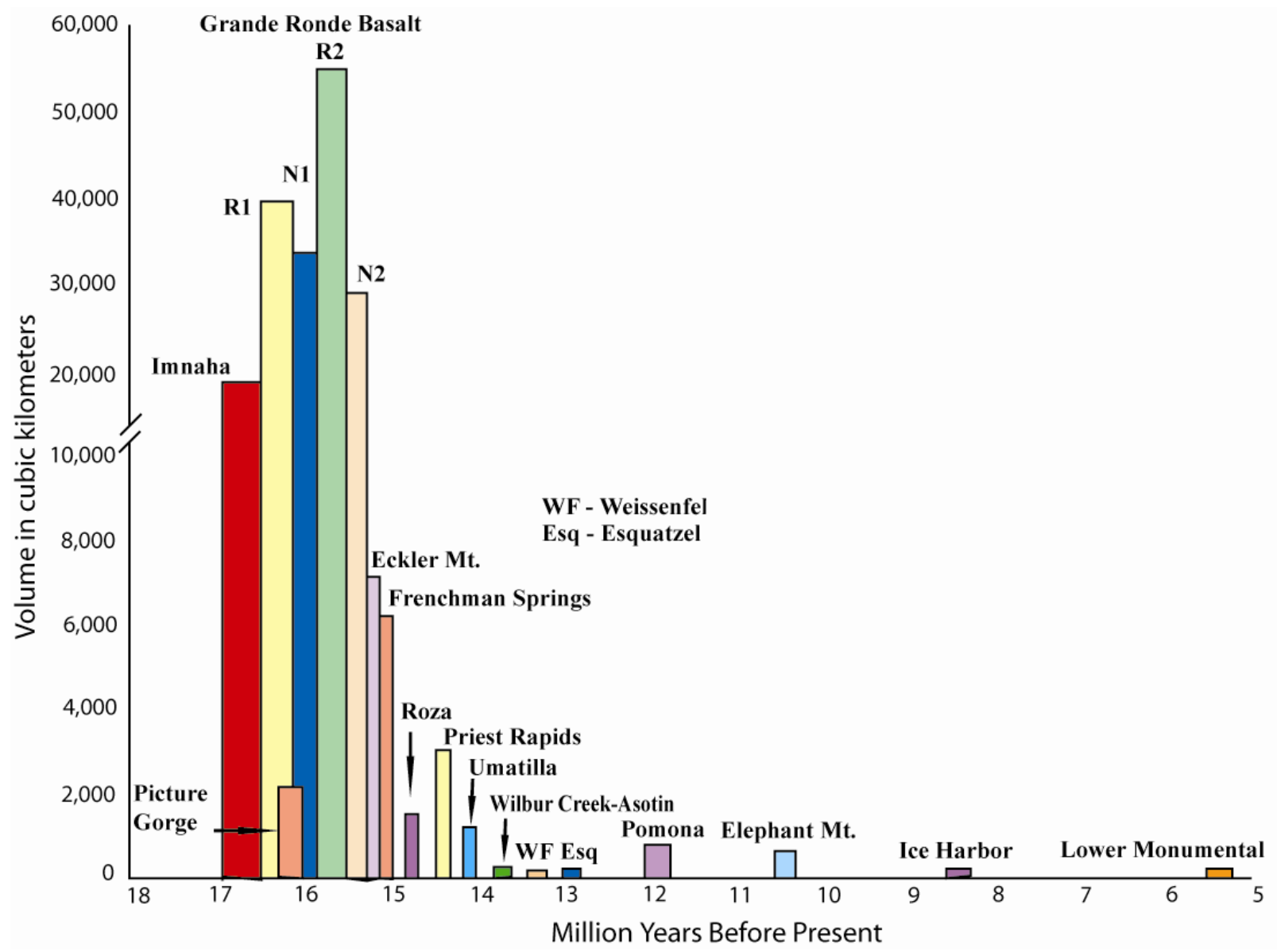

Figure 5. Volume of Columbia River Basalt Group Eruptions Over Time. R1, N1, R2, and N2 are magnetostratigraphic units of the Grande Ronde Basalt.

\subsubsection{Stratigraphic Subdivisions of the Columbia River Basalt Group}

Detailed study and mapping of the Columbia River flood basalts have demonstrated that significant variations in lithological, and geochemical properties and paleomagnetic polarity exist between flows (and packets of flows) which have allowed the establishment of stratigraphic units that can be reliably identified and correlated on a regional basis (e.g., see Swanson et al. 1979). Figure 4 presents the current stratigraphic nomenclature for the CRBG. Based on these abilities to recognize the flows, the Columbia River Basalt Group has been divided into five formal formations (Swanson et al. 1979): Imnaha, Grande Ronde, Picture Gorge, Wanapum, and Saddle Mountains Basalt.

Figure 6 is a geologic map showing the Columbia River Basalt Group units exposed at the surface. Details of individual units are given in Appendix A. In the Columbia Basin, flows of the Saddle Mountains Basalt are exposed at the surface, with underlying flows of the Wanapum and Grande Ronde Basalts mainly in the subsurface. Figure 7 shows the thickness for the entire Columbia River Basalt Group and shows the greatest thickness of the basalt occurs in the center of the Columbia Basin in the Pasco Basin. 

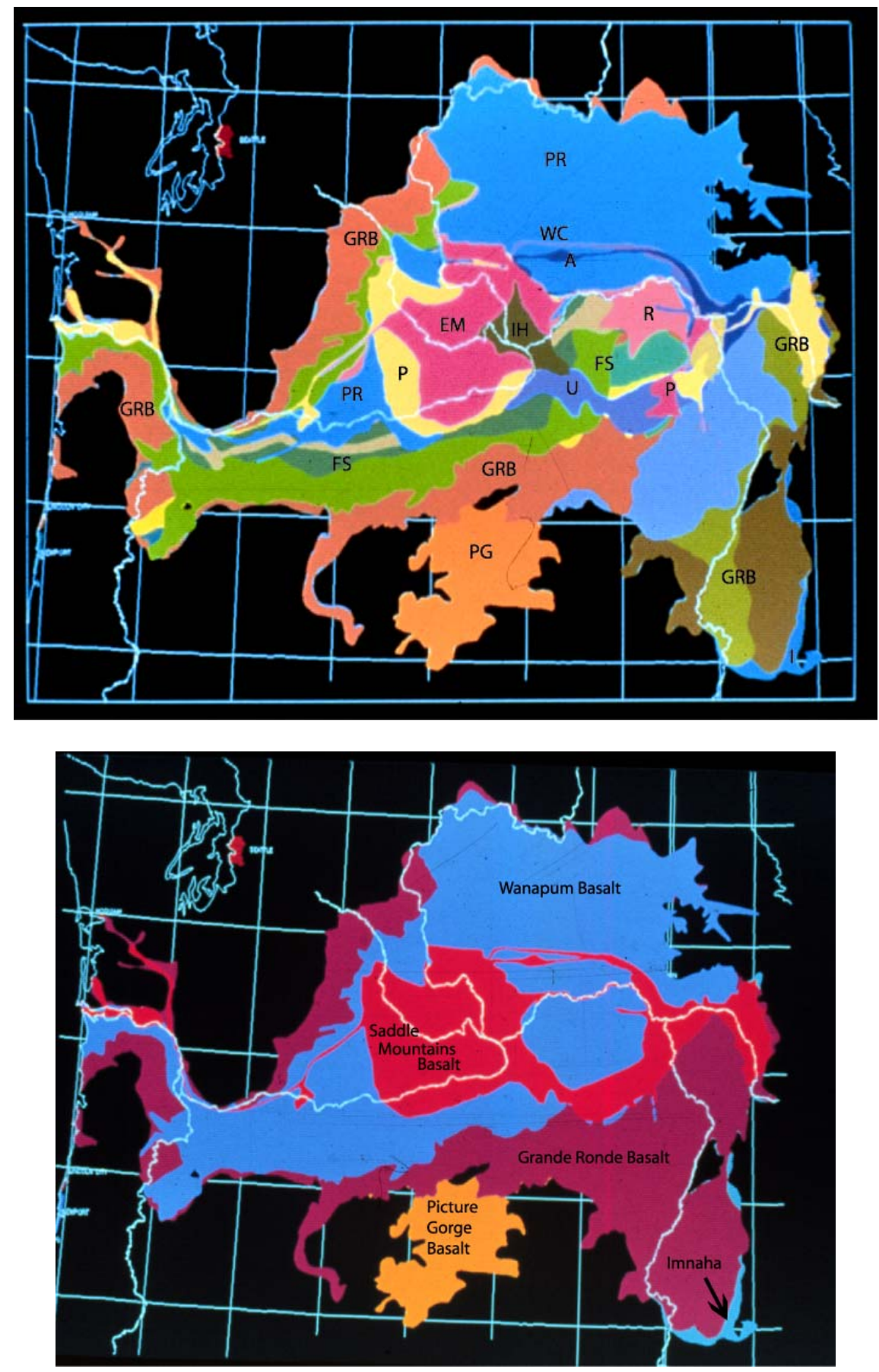

Figure 6. Geologic Map of the Columbia River Basalt Group. Top: Geologic map showing individual units. Bottom: Distribution of five formations of the Columbia River Basalt Group. GRB = Grande Ronde Basalt, PG = Picture Gorge Basalt, FS = Frenchman Springs Member, $\mathrm{R}=$ Roza Member, PR - Priest Rapids Member, $\mathrm{U}=$ Umatilla Member, A = Asotin Member, WC = Wilbur Creek Member, $\mathrm{P}=$ Pomona Member, EM = Elephant Mountain Member, $\mathrm{IH}=$ Ice Harbor Member. 


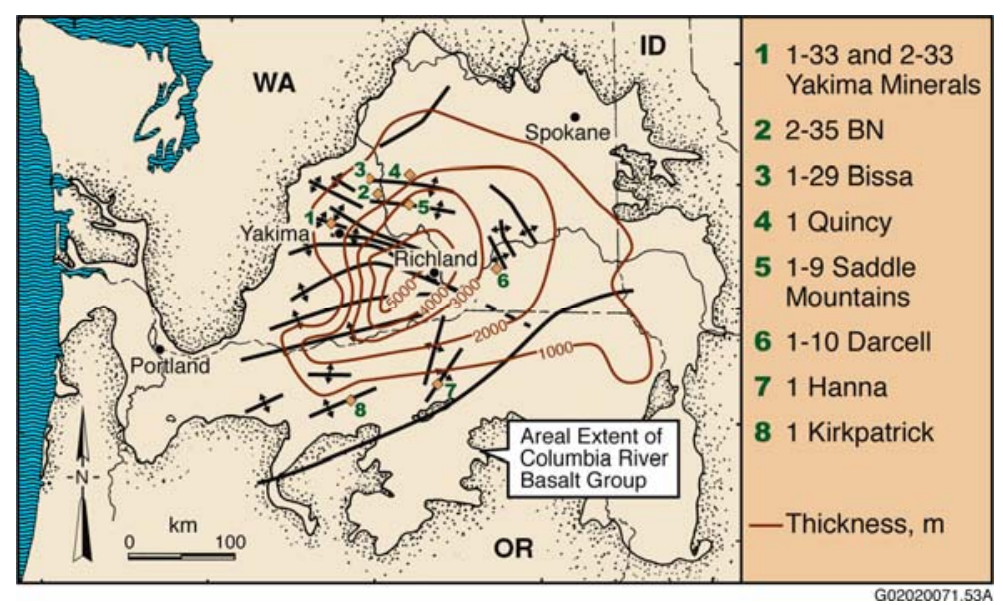

Figure 7. Thickness Map of the Columbia River Basalt Group 


\subsection{Major Internal Features of Columbia River Basalt Group Flows}

Intraflow structures are primary, internal features of basalt flows exhibiting grossly uniform macroscopic characteristics. These features originate during the emplacement and solidification of each flow and result from variations in cooling rates, degassing, thermal contraction, and interaction with surface water. They are distinct from features formed by tectonic processes.

Columbia River Basalt Group flows typically consist of a permeable flow top, a dense, relatively impermeable flow interior, and a variable flow bottom. Figure 8 depicts the various types of intraflow structures that are typically observed in a basalt flow; most flows do not show a complete set of these structures. Sedimentary layers (interbeds) and basalt intraflow zones (vesicular flow tops, brecciated flow tops, basal pillow complexes, and basal breccia zones) serve as the primary aquifers in the region, while dense flow interiors commonly act as aquitards. The contact zone between two individual basalt flows (i.e., a flow top and overlying basalt flow bottom) is referred to as an interflow zone.

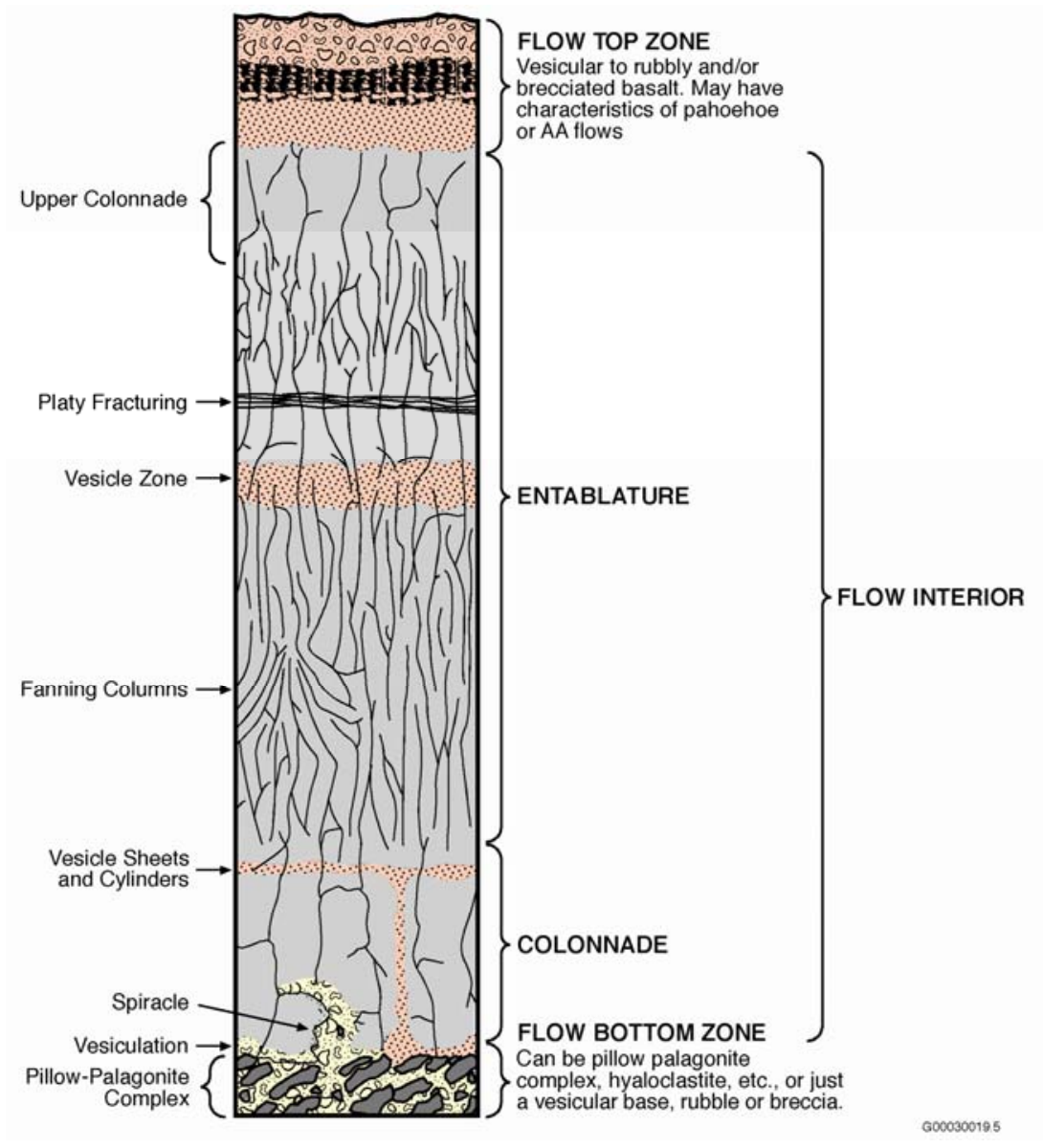

Figure 8. Major Basalt Flow Features of a Columbia River Basalt Group Lava Flow 


\subsection{Flow Top}

The flow top is the chilled, glassy upper crust of the flow. It may consist of vesicular to scoriaceous basalt, displaying pahoehoe, or a'a features, or it may be rubbly to brecciated (Waters 1960; Diery 1967; Swanson and Wright 1981). Typically, the flow top occupies approximately $10 \%$ of the thickness of a flow; however, it can be as thin as a few centimeters or occupy almost the entire flow thickness.

- Pahoehoe. Pahoehoe-like flow top is a type of lava flow that has a glassy, smooth, and billowy or undulating surface. Almost all Columbia River Basalt group flows are classified as pahoehoe. The surface is referred to as ropy.

- A'a. An a'a lava flow is one that has a rough, fragmental surface. It is blocky lava consisting of scoria. Columbia River Basalt Group lavas are not considered to be a'a lava flows. The closest similarity is the rubbly to brecciated flow top.

- Rubbly to Brecciated. Flow top breccia occurs as a zone of angular to subrounded, broken volcanic rock fragments that may or may not be supported by a matrix and is located adjacent to the upper contact of the lava flow. An admixture of vesicular and nonvesicular clasts bound by the original glass often characterizes the breccia zone. The percentage of the breccia to rubbly surface is typically less that $30 \%$ but locally can be as much as $50 \%$ of the flow. This type of flow top usually forms from a cooled top that is broken up and carried along with the lava flow before it ceases movement.

\subsection{Flow Bottom}

The basal part of a Columbia River basalt flow is predominantly a thin, glassy, chilled zone a few centimeters thick, which may be vesicular. Where basalt flows encounter bodies of water or saturated sediments, the following features may occur:

- $\quad$ Pillow-palagonite complexes. Discontinuous pillow-shaped structures of basalt formed as basalt flows into water. Space between the pillows is usually hydrated basaltic glass (palagonite) and hyaloclastite.

- Hyaloclastic complexes. These are deposits resembling tuff and form as basalt shatters as it flows into water.

- $\quad$ Foreset bedded breccias. These form as basalt flows into water and builds out its own delta. Hyaloclastite and pillow-plagonite usually compose the forset beds

- $\quad$ Peperities. Breccia like mixture of basalt (but can be hyaloclastite or plagonite) and sediment. Forms as basalt burrows into sediments.

- $\quad$ Spiracles. A fumarolic vent-like feature that forms during a gaseous explosion in fluid lava that flows over water-saturated soils or ground. 
Typically, many thick flow bottoms observed within the Columbia Basin are associated with pillowpalagonite zones. Pillow-plagonite zones have been observed that are greater than $23 \mathrm{~m}$ thick and constitute more than $30 \%$ of the flow.

\subsection{Flow Interior}

Within the interior of a basalt flow, the predominant intraflow structures are zones characterized by patterns of cooling joints. These are commonly referred to as colonnade and entablature (Tomkeieff 1940).

The colonnade consists of relatively well-formed polygonal columns of basalt, usually vertically oriented and typically $1 \mathrm{~m}$ or larger in diameter (some as much as $3 \mathrm{~m}$ have been observed). Colonnade, as defined by Tomkeieff (1940), occurs in the basal portion of flows. In Columbia River basalts, colonnade can make up the entire flow or there can be multiple colonnades present, which are tiered with entablatures.

Entablature is composed of irregular to regularly jointed small columns frequently less than $0.5 \mathrm{~m}$ in diameter. Entablature columns are commonly fractured into hackly, fist-sized fragments that can mask the columnar structure. Entablatures typically display a greater abundance of cooling joints than do colonnades. Entablature columns can be oriented vertically, exhibit regular patterns such as rosettes and fans, or appear completely disordered. Flows at a few localized occurrences on the Columbia Plateau have been observed to consist wholly of entablature (Waters 1960).

\subsection{Other Internal Features}

Other intraflow features observed within the interior of Columbia River basalt lava flows include the following:

- Vesicle pipes and cylinders. Vesicle pipes and cylinders are vertical, cylindrical zones of gas bubbles that form as gas evolves from that lava and rises toward the top of the flow. The difference between pipes and cylinders is size; cylinders are larger but there is no defined size break. Vesicle cylinders, pipes and sheets usually occur in relatively thin flows (5-30 m) that are composed of mainly colonnades and flow tops. Vesicle pipes and cylinders can be useful flow direction indicators, as the top of the pipe or cylinder is often inclined in the direction of flow.

- Vesicle sheets. Vesicle sheets are horizontal to subhorizontal layers of vesicles. They typically are fed by vesicle pipes and cylinders, and form below the solidification front. Vesicle zones within the interior of thicker flows can be thin $(\mathrm{cm})$ to meters thick and can be laterally continuous, sometime for kilometers.

- Vesicle zones. Vesicle zones are usually larger than vesicle sheets but probably form in much the same way. Vesicle zones can be up to several meters thick and are typically found in the interior part of the lava flow. 
- Laminae or dispersed diktytaxitic vesiculation. Diktytaxitic vesiculation or interstitial microvesiculation with crystal linings can occur anywhere but is most prominent in thinner flows.

- $\quad$ Platy fracturing. Platy fracturing consists of zones of horizontal to subhorizontal anastomosing joints across columns and vertical to near vertical curvilinear fractures. These are commonly observed in the field but are not easily recognized during drilling. This phenomenon is thought to have formed by stress release as weathering or other processes remove rock from above.

- Lava tubes. Lava tubes have not been observed in Columbia River Basalt Group flows. This is because the flows were emplaced as sheets and were not tube fed as Hawaiian flows are.

- Sag flowouts. Sag flowouts are described as localized zones of complex tiering of colonnades and entablatures with some isolated flow-top material occurring below the top of the flow. A sag flowout is thought to have formed as the result of lava draining from a partly solidified flow leaving room for vesiculation to occur at the top of the remaining liquid.

\subsection{Cooling Joints}

Cooling joints are ubiquitous features in Columbia River Basalt Group flows that formed during solidification of the flows. The cooling joints form the columns of the entablature and colonnade, subdivisions of columns and zones of irregular blocks. Cooling joints result from tensional stress in response to contraction of solidified portions of a flow as it cooled below the solidius (Spry 1962).

Cooling joints are distinct from secondary tectonic fractures such as faults, shear zones, and joint sets. These secondary features are distinguishable by their appearance and occurrence. Tectonic fractures typically occur in sets of parallel to subparallel, closely spaced fractures. They often are associated with breccias and clay minerals and can often be recognized by offsets or repeats in the stratigraphy. Such differences can be recognized in exposure but are difficult to detect in borehole data.

Frequency and spacing of cooling joints measured in outcrops indicate that typical joint densities range from 1 to 37 joints per meter with entablatures showing a greater number of joints per meter than colonnades.

The spacing of cooling joints (fracture per number of meters) appears to follow a log normal distribution for groups of cooling joints with similar attitudes. This was illustrated by Meints (1986) in a study of jointing in an exposure of the Rocky Coulee flow of the member of Sentinel Bluffs (Figures 4 and 9). Meints (1986) found spacing of cooling joints to be highly variable both between flows and within flows and cannot be used to differentiate flows, intraflow structures, or even localities that are not close together.

Cooling joint widths average between 0.1 and $0.3 \mathrm{~mm}$. Histogram plots of cooling joint widths show that the distribution of widths is not symmetrical but is skewed with the smaller widths more common than larger widths. 

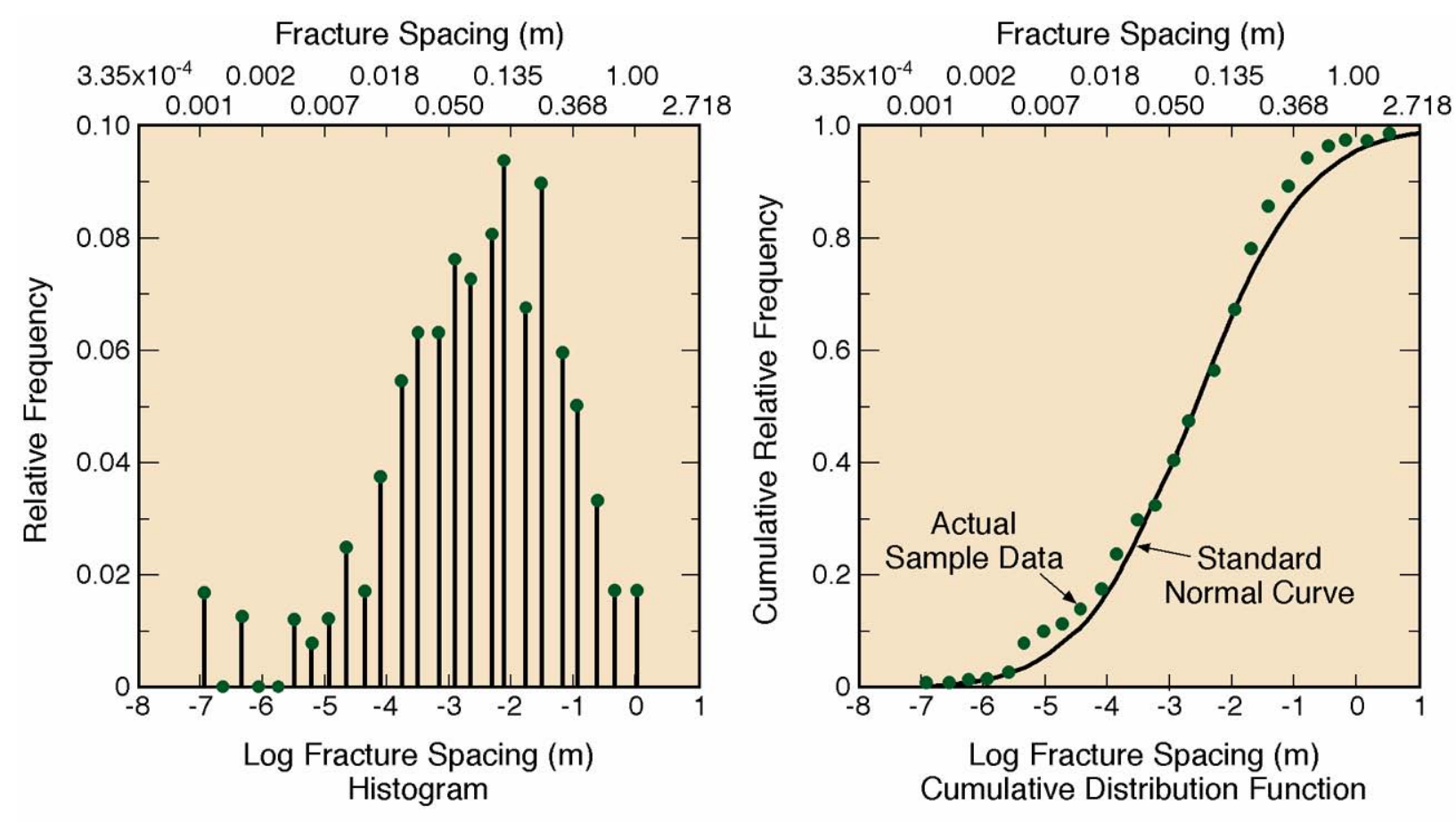

G02020071.55

Figure 9. Histogram (left) and a Cumulative Distribution Function (right) for Cooling Joint Spacing for High-Angle Joints from an Exposure of the Rocky Coulee Flow of the Member of Sentinel Bluffs from Meints (1986)

Of the 1,454 cooling joints logged in drill core for the Sentinel Bluffs Member flows, 83\% were completely filled with secondary minerals and at least $17 \%$ were partly filled (Department of Energy 1988). The vast majority of unfilled or partly unfilled cooling joints were smaller in width than $0.3 \mathrm{~mm}$. Clay minerals are the predominant infilling material followed by silica and zeolites.

\subsection{Intraflow Structural Variation}

Intraflow structures can be continuous for great distance but the thickness of intraflow structures is often highly variable. Lateral variations occur gradually in some cases and very abruptly in other cases. The primary factor that appears to control the variations is the environment in which the feature formed. Studies in the central Columbia Basin (Department of Energy 1988) showed that lateral changes in the member of Umtanum (Figure 4), which has a rubbly to brecciaed flow top, extremely thick entablature and very thin colonnade, occur over relatively short distances. However, studies on the McCoy Canyon flow of the member of Sentinel Bluffs (Figure 4), which has a normal flow top with a thick entablature and thick colonnade, displays gradual changes with distance. 


\subsection{Identifying Columbia River Basalt Group Flows}

Lava flows of the CRBG are identified using a combination of lithology, paleomagnetic properties, and chemical composition. Experience is the best way of making correct identifications but the chemical composition provides the least ambiguous way of properly identifying a lava flow. Table A.1 shows the chemical composition of the larger lava flows of the Columbia River Basalt Group. Although this selection does not include every flow known, it provides compositions of the ones that will be of most importance for characterization because of their great lateral extent. The main compositional characteristics of CRBG flows have been described by Hooper (2000).

Typically $\mathrm{TiO}_{2}, \mathrm{P}_{2} \mathrm{O}_{5}$, and $\mathrm{MgO}$ provide the most reliable indicators used to identify flows. Saddle Mountains Basalt flows are some of the most diverse ranging all across the range of analyses. Wanapum Basalt flows are typically characterized by higher $\mathrm{FeO}$ and $\mathrm{TiO}_{2}$. Grande Ronde Basalt flows are generally a closely grouped set of flows that are difficult to divide. Reidel et al. (1989a) summarize the main differences used to discriminate these flows. 


\subsection{Columbia River Basalt Group Dikes: The Chief Joseph Dike Swarm}

Based on previous work as well as his own reconnaissance mapping, Waters (1961) identified three dike swarms as feeders to the CRBG: the Monument, Grande Ronde, and Cornucopia. Based on additional mapping, Taubeneck (1970) found no gap between the northerly Grande Ronde and southerly Cornucopia swarms and merged them into a single giant swarm that he named the Chief Joseph (Figure 10). Chief Joseph dikes fed the main phase of CRBG volcanism that dominates the Columbia Plateau, including large-volume (>2,500 $\mathrm{km}^{3}$ ) flows of the Grande Ronde and Wanapum Basalts.

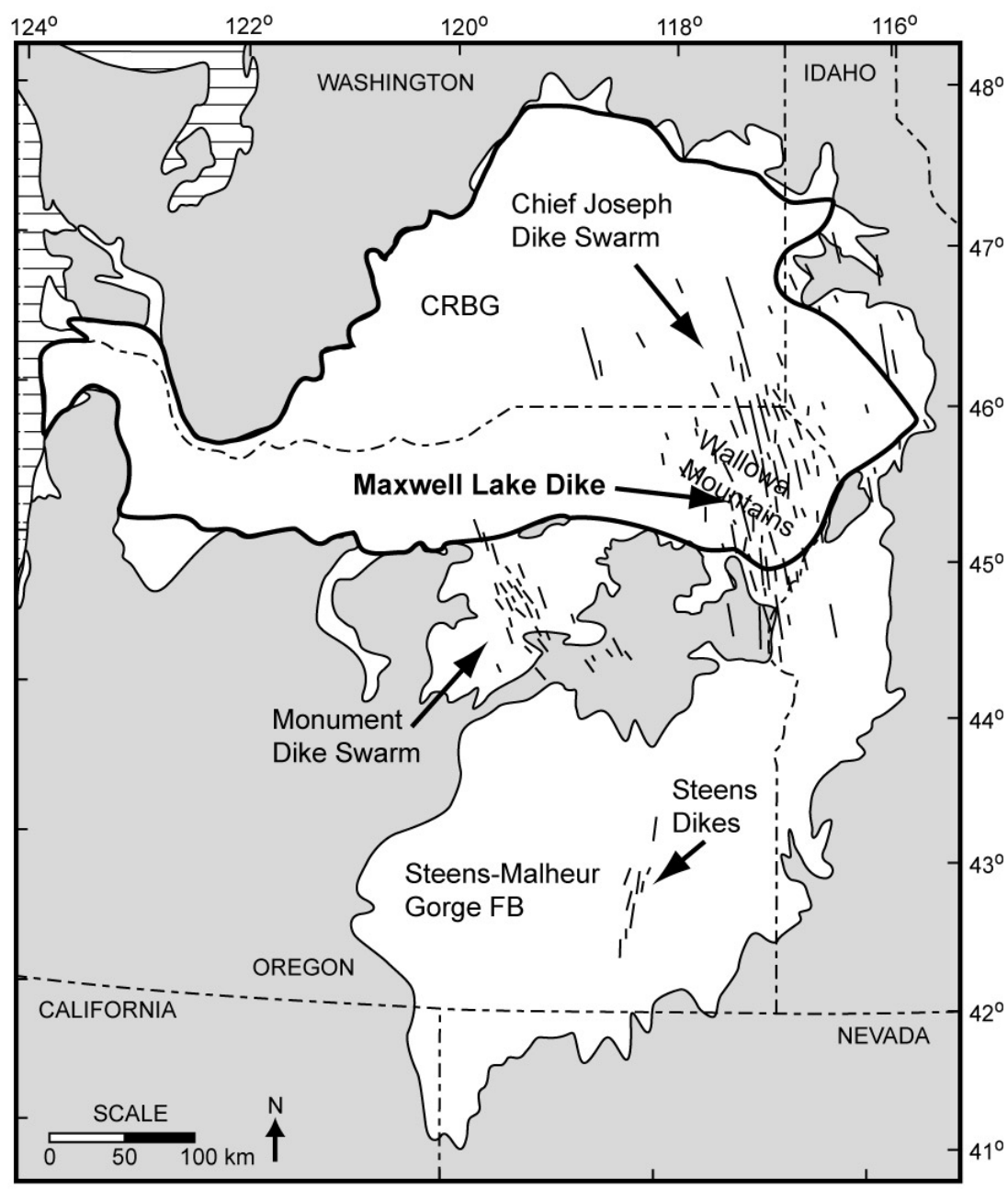

Figure 10. Areal Extent of Columbia River Basalt Group from Figure 1. The areal extent of the member of Wapshilla Ridge (from Reidel et al. 1989a) is shown by the heavy dark line and the Maxwell Lake dike is shown in relation to known dikes and vents. See Figure 11 for more detailed explanation of dikes and vents. 
Taubeneck (1970) estimates that at least 21,000 dikes occur in the Chief Joseph swarm at the level of the regional unconformity below the CRBG. Overall, dikes are exposed at deeper stratigraphic levels southward through the swarm, due to uplift and erosion of the Wallowa and Blue Mountains. On the Columbia Plateau, dikes are dominantly hosted in older CRBG flows (Grande Ronde or Imnaha). In the Wallowa Mountains (Figure 10) and southward, dikes are hosted in pre-Tertiary rocks, dominantly in granitoids and fewer in meta-sediments. Concentrations of dikes diminish rapidly at or within several km of granitoid pluton margins, suggesting that dikes are preferentially hosted in these plutons, where local jointing controls their orientation (Taubeneck and Duncan 1997; Taubeneck 1998).

\subsection{Dike Distribution and Geometry}

In general, observed dike density increases from north to south across the Chief Joseph dike swarm (and hence is a function of depth of erosion). On the Columbia Plateau, dike concentration is generally less than 3 dikes per $\mathrm{km}^{2}$ (Taubeneck 1970). This concentration increases to around 8 dikes per $\mathrm{km}^{2}$ in the Wallowa Mountains (Taubeneck 1970), and is as great as 10 to 12 dikes per $\mathrm{km}^{2}$ south of the Wallowas (Taubeneck 1989, 1990). Dikes are rarely isolated but instead occur in closely spaced clusters of 7-12 dikes per $\mathrm{km}^{2}$; presumably, each cluster or sub-swarm represents an eruptive axis for CRBG volcanism (Taubeneck and Duncan 1997).

The overall trend of the Chief Joseph swarm is $\mathrm{N} 10^{\circ} \mathrm{W} \pm 10^{\circ}$ (Taubeneck 1970), yet each sub-swarm has its own distinct orientation (Taubeneck and Duncan 1997). The majority of dikes dip within $30^{\circ}$ of vertical (Taubeneck 1970). Dikes hosted in pre-Tertiary wallrock in general are thicker than those hosted in CRBG flows, averaging $7.3 \mathrm{~m}$ and $5.8 \mathrm{~m}$ thick, respectively, but rarely exceeding $25 \mathrm{~m}$ thick (Taubeneck 1970). Dike length ranges from a few hundred meters to $5 \mathrm{~km}$, although many dikes occur in en-echelon segments (Taubeneck 1970).

\subsection{Dike-Wallrock Relationships}

Dikes hosted in CRBG flows are chilled against their wallrock, commonly with cm-thick glassy margins (Taubeneck 1970). The majority of dikes hosted in granitoids have an aphyric chilled margin of basalt (few cm-thick) at the dike-wallrock contact. Rare dikes have caused partial melting in their wallrock; these partial melt zones (preserved as silicic glass plus mineral phases) are up to one-half the thickness of the dike and contain up to $50 \%$ quenched silicic melt. Dikes may also locally erode the chilled basalt at their margins, producing localized (cm-scale) zones of wallrock breakdown and a few \% melting. Only a handful of dikes contain granitoid or metasedimentary xenoliths that range from a few $\mathrm{cm}$ to $6 \mathrm{~m}$ in diameter (Taubeneck 1970). The majority of these xenoliths appear to be locally derived from stoping of wallrock. 


\subsection{Correlation of Dikes with Flows}

Most Chief Joseph dikes have been identified to formation level, and a few have been mapped to unit level and correlated with individual CRBG flows (Figure 11). In general, dikes of Grande Ronde and Wanapum basalts are located throughout the swarm, although exposures of Wanapum dikes suggest that they extend farther north than Grande Ronde dikes (Figure 11). Saddle Mountains dikes occur in the northern half of the Chief Joseph swarm and are localized near the center of the Columbia Plateau (Figure 11). Imnaha dikes are only exposed near the Oregon-Washington border and southward, but northern Imnaha dikes may be buried by younger flows.

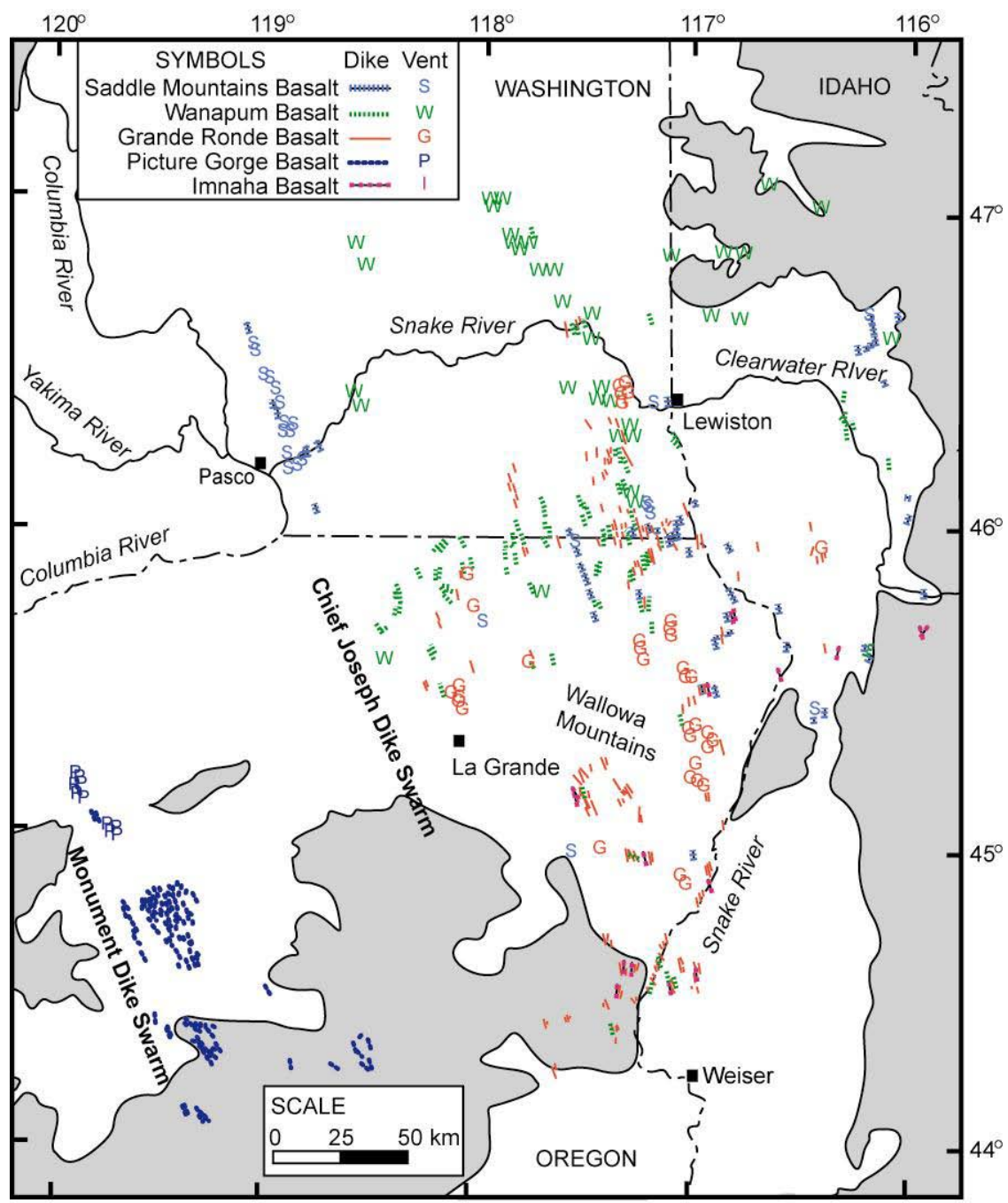

Figure 11. Location for the Known Feeder Dikes and Vents for the Columbia River Basalt Group. Modified after Tolan et al. (1989) and Camp and Ross (2004). 
Many Wanapum and Saddle Mountains dikes have been correlated with individual flows based on direct observation of dike-flow connections. For example, the vent-fissure system for the Frenchman Springs flows, Ice Harbor flows, and the Roza flow are well known (Swanson et al. 1975; Martin 1989). In the Grande Ronde Basalt, the Teepee Butte vent and flow system has been directly observed (Reidel and Tolan 1992), as has the Umatilla Member (Reidel et al. 1992). In the absence of direct dike-flow connections, dikes have been successfully correlated with CRBG flows on the basis of compositional, petrographic, and paleomagnetic data (e.g., Price 1977; Ross 1983; Mangan et al. 1986; Reidel et al. 1992). The major and trace element composition of CRBG units is well established (e.g., Hooper 2000) and provides a basis for compositional identification of dikes and dike-flow correlations. 


\subsection{Columbia River Basalt Group Eruption and Emplacement Rates}

Emplacement rates and mechanisms of large-volume flood basalts have been a matter of controversy. Early workers (Shaw and Swanson 1970) suggested emplacement as turbulent flows racing across the landscape in weeks to months. However, analogy to the inflated pahoehoe flows observed in Hawaii (i.e., Hon et al. 1994; Self et al. 1996) (for example) suggested that Columbia River flood basalts were emplaced as large, inflated flow fields. Flow inflation occurs as cm-scale lobes of lava develop a chilled, viscoelastic skin, and then expand with continued injection of fluid lava. Ho and Cashman (1997) found less than $0.04^{\circ} \mathrm{C} / \mathrm{km}$ of heat loss along the 500-km-long Ginko flow, suggesting emplacement under an insulating crust and/or rapid emplacement by fast-laminar flow. Thordarson and Self (1998) described lobes and other inflation structures in the Roza Member of the CRBG. Inflation is also consistent with compositional data; compositionally zoned Saddle Mountains Basalt (Reidel and Fecht 1987; Reidel 1998) and Grande Ronde Basalt (Reidel 2005) flows have been described where progressively younger lava is preserved towards the center in a single cooling unit.

Whereas flow inflation is recognized as a critical mechanism for flood basalt emplacement, controversy persists over eruption and emplacement rates. Slow emplacement over years to a few decades is advocated in the CRBG based on conductive cooling models in the Roza (Thordarson and Self 1998), and is supported by thermal models (Keszthelyi and Self 1998). Compositional data, however, is more consistent with eruption and emplacement over timescales of weeks to months. Reidel (1998; 2005) and Reidel and Fecht (1987) documented examples where two or more flows were preserved in individual dikes and vents, yet mixed together to form a single flow more than $200 \mathrm{~km}$ from the source, requiring rapid emplacement.

Recently, Petcovic and Grunder (2003) analyzed wallrock melting reactions in tonalite adjacent to the Maxwell Lake dike, a likely feeder to the member of Wapshilla Ridge, probably the largest of all Grande Ronde Basalt eruptions. The quenched partial melt zones adjacent to this dike preserve an integrated thermal record of heating during magma flow in the dike and cooling after flow ceased. Constrained by this field example, Petcovic and Dufek (2005, in review) developed two-dimensional thermal models of dike injection, flow, and cooling. Model results suggest that the dike was active for 3-4 years and likely represents a long-lived point source in flood basalt eruptions.

\subsection{The Roza Member Vent System}

The Roza Member is one of the most distinctive units within the Columbia River Basalt Group. It is characterized by the presence of single clear to amber-colored plagioclase phenocrysts between 0.3 and 1 $\mathrm{cm}$ in length that comprise 5 to 10 modal percent of the flow. This characteristic made the Roza Member an important stratigraphic marker bed during the development of the Columbia Basin (Irrigation) Project (Grolier and Bingham 1971). A single Roza flow was recognized in its type area near Yakima, Washington; however, as many of four flow units are recognized across the 40,300 $\mathrm{km}^{2}$ expanse of the Roza (Mackin 1961; Bingham and Walters 1965; Bingham and Grolier 1966; Lefevbre 1970; Martin 1989, 1991; Thordarson and Self 1998). The total volume of the Roza flows has been estimated to be 
approximately 1,300 $\mathrm{km}^{3}$ (Tolan et al. 1989). The Pullman-Moscow area lies just to the east of the zeroedge of the Roza flows. Flow thickness increases rapidly to $>30$ meters $10 \mathrm{~km}$ west of the zero-edge.

Flow direction indicators (i.e., inclined pipe vesicles, spiracles, vesicle cylinders) within the Roza lavas of the western and northwestern Columbia Plateau suggested that the lavas were erupted from vents in the southeastern Columbia Plateau (Lefevbre 1966, 1970; Schmincke 1967). Bingham and Grolier (1966) interpreted outcrops of phyric tephra interbedded with thin Roza flows near Winona, Washington, as Roza tephra cones. Subsequently, Swanson et al. (1975) described a 175-km long, north to northnorthwest-trending linear vent system for the Roza Member. They identified 19 areas along a $120 \mathrm{~km}$ long zone in which the presence of a vent was recognized or could reasonably be inferred from the occurrence of oxidized tephra and dikes of Roza lithology. Within this zone, dikes occurred both singly and in groups. For instance, at least seven Roza dikes are exposed in road cuts along SR 129 in the north wall of the Grande Ronde River canyon in far southeastern Washington. These dikes can be traced up the canyon wall to the north where they trend into Big Butte, a small volcanic shield. Detailed geochemical analyses, integrated with field work, allowed correlation of specific segments of the vent system with individual units within the Roza Member (Martin 1989, 1991). In general, there appears to be a northward shift of eruptive activity during the emplacement of the Roza Member, although vents for one of the older Roza units (II) are distributed along the entire length of the system.

\subsection{Estimates of CRBG Eruption Rates from Dike-Wallrock Relationships}

\subsubsection{The Maxwell Lake Dike and Member of Wapshilla Ridge}

Wallrock melting reactions in the Maxwell Lake dike were examined in order to estimate dike longevity and, consequently, eruption rates of the flow it fed (Petcovic and Grunder 2003; Petcovic and Dufek 2005 in review). The dike (Figure 10) is hosted in biotite- and hornblende-bearing tonalite of the Wallowa Batholith. It strikes $\mathrm{N} 20^{\circ} \mathrm{E}$, dips about $75^{\circ} \mathrm{W}$, and continues in en-echelon segments for at least one $\mathrm{km}$ along strike. Paleodepth at the time of dike emplacement was about $2 \mathrm{~km}$. Wallrock melting reactions (detailed in Petcovic and Grunder 2003) produced up to 47 vol. \% quenched melt (silicic glass plus quench crystals) via biotite and hornblende dehydration-melting reactions. In the northern of two en-echelon segments examined, the dike is 6-11 m thick where it is chilled against wallrock, and 11-15 m thick where it caused wallrock melting. Wallrock melt zones parallel to both dike margins make up $\sim 60 \%$ of the total length of dike exposed. In the southern en-echelon segment, the dike is 3-8 $\mathrm{m}$ thick with continuous 2-4 m thick wallrock melt zones.

On the basis of available compositional data, the Maxwell Lake dike has been tentatively correlated with the member of Wapshilla Ridge (Grande Ronde Basalt). The Wapshilla Ridge unit is comprised of as many as 8-10 flows of narrow though variable compositional range, and belongs to the R2 paleomagnetic interval of Grande Ronde volcanism ( 15.5 Ma; Reidel et al. 1989a). It is also widely distributed across the CRBG province (Figure 10), and is the most voluminous member of the Grande Ronde at an aggregate volume of $\sim 40,000 \mathrm{~km}^{3}$. Individual flows of the Wapshilla Ridge are commonly in excess of 2,500 $\mathrm{km}^{3}$ with some flows probably exceeding $5,000 \mathrm{~km}^{3}$. 


\subsubsection{Thermal Modeling Results}

Petcovic and Dufek (2005 in review) used two series of models constrained by the field example of the Maxwell Lake dike in order to assess the development of wallrock melting due to basalt intrusion. In a series of preliminary static conduction simulations, the timing between dike injection(s) and duration of basalt flow in the dike was varied. The static conduction simulations were developed to explore a range of conditions that could have given rise to the observed wallrock melt zones. In order to refine initial calculations and determine magma flow rates in the dike, advective transport simulations were developed. Both series of models used a finite volume numerical method, with a predictor-corrector algorithm to compute the partitioning of enthalpy into sensible and latent heat during phase change processes. One principle difference between this approach and previous calculations (i.e., Bruce and Huppert 1990; Fialko and Rubin 1999) is the incorporation of non-linear melt fraction to temperature relationships specific to the magma/solid composition.

Results of static conduction modeling constrained by the Maxwell Lake dike field example suggested that sustained basalt flow for 3-4 years caused development of the melt zones observed in the dike. Advective transport simulations suggested that the initial basalt velocity in the dike center was $\sim 10 \mathrm{~m} / \mathrm{s}$, but that basalt at the dike margin solidified, causing constriction and slowing of flow. After about 60 days, magma in the dike reached a sustained velocity of $\sim 2 \mathrm{~m} / \mathrm{s}$ for the duration of flow. Wallrock melting was initiated after $\sim 1$ year of flow and the wallrock had dropped below its solidus temperature within $\sim 2$ years after flow ceased. The thickness, distribution, and fractions of wallrock melt zones produced by advective transport modeling closely approximate field observations of the Maxwell Lake dike.

\subsubsection{Implications for CRBG Flow Emplacement}

Results from the static conduction simulations allow limits to be estimated for eruption rates of the Wapshilla Ridge flow. Assuming that the Maxwell Lake dike fed an entire Wapshilla Ridge flow of $5,000 \mathrm{~km}^{3}$ over a period of 3 to 4 years yields an average eruption rate of $3-5 \mathrm{~km}^{3} /$ day (Table 1 ), which is a maximum estimate. The eruption rate would have been lower if flow in the dike were intermittent rather than continuous. Intermittent flow has been documented in historical basalt eruptions and during eruption of the Teepee Butte (Reidel and Tolan 1992). Some pauses during eruption cannot be ruled out, yet the lack of internal contacts as well as the regular textural progression across the dike and wallrock melt zones is more consistent with nearly continuous flow and a single cooling history.

The advective transport simulation provides a minimum estimate of basalt flux in the dike. Flow was assumed to be localized along the portions of the Maxwell Lake dike with partially melted wallrock margins, which yields an initial basalt flux of about $0.8 \mathrm{~km}^{3} /$ day waning rapidly to a sustained flux of about $0.1 \mathrm{~km}^{3} /$ day (Table 1 ). Waning discharge is commonly documented in basaltic eruptions (e.g., Wadge 1981). However, cumulative magma discharge under this scenario produced a total flow volume of only $150 \mathrm{~km}^{3}$ over 4 years. Clearly other fissure segments must have fed the same flow in order to produce a 2,500-5,000 $\mathrm{km}^{3}$ cumulative volume typical of Grande Ronde flows. In historical basalt eruptions (e.g., Laki 1783, Mauna Loa 1984), and as proposed for the Roza fissure system (Martin 1991; Self et al. 1997) eruptive activity migrated along the length of the dike-fissure system, with each 
Table 1. Estimates of Eruption Rates for Selected CRBG Flow Units

\begin{tabular}{|c|c|c|c|c|c|c|c|c|}
\hline Flow Field & $\begin{array}{c}\text { Generic CRBG } \\
\text { Dike } \\
\end{array}$ & Roza Member & Ice Harbor Member & Teepee Butte & $\begin{array}{c}\text { Sentinel Bluffs } \\
\text { Member }\end{array}$ & $\begin{array}{l}\text { Umatilla } \\
\text { Member }\end{array}$ & Roza Member & $\begin{array}{c}\text { Wapshilla Ridge } \\
\text { Member }\end{array}$ \\
\hline $\begin{array}{l}\text { Flow field } \\
\text { volume }\left(\mathrm{km}^{3}\right)\end{array}$ & Not given & 1,500 & 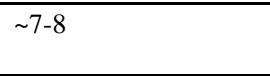 & 5,000 & 10,000 & 720 & 1,300 & $2 \sim 50,000$ \\
\hline $\begin{array}{l}\text { Flow field } \\
\text { areal extent } \\
\left(\mathrm{km}^{2}\right)\end{array}$ & Not given & 40,000 & $\sim 700$ & 52,000 & 82,461 & 15,110 & 40,300 & $\sim 100,000$ \\
\hline $\begin{array}{l}\text { Individual flow } \\
\text { volume }\left(\mathrm{km}^{3}\right)\end{array}$ & $\begin{array}{l}\text { "Typical" = } 100 \\
\text { "Large" = } 1000\end{array}$ & 700 per cooling unit & 0.1 per cooling unit & $\begin{array}{l}\text { Limekiln Rapids } \\
=840 \\
\text { Joseph Creek = } \\
1,850 \\
\text { Pruitt Draw = } \\
2,350\end{array}$ & $\begin{array}{l}\text { Museum =2349 } \\
\text { Spokane Falls = } \\
777 \\
\text { Stember Creek = } \\
1192 \\
\text { California Creek- } \\
\text { Airway Heights = } \\
1543 \\
\text { McCoy Canyon = } \\
4278\end{array}$ & 310 approx. & Single eruption & $\sim 5,000-10,000$ \\
\hline $\begin{array}{l}\text { Emplacement } \\
\text { time }\end{array}$ & Days to weeks & 7 days & 10 days & $\begin{array}{l}\text { Days-weeks, } \\
\text { maybe months }\end{array}$ & Months & Months & $\begin{array}{l}0.4-4.2 \text { years for } \\
\text { individual flows. } \\
6-14 \text { years for } \\
\text { flow field }\end{array}$ & $\begin{array}{l}\text { 3-4 years for } \\
\text { individual flow }\end{array}$ \\
\hline $\begin{array}{l}\text { Volumetric } \\
\text { eruption rate } \\
\left(\mathrm{km}^{3} / \text { day }\right)\end{array}$ & $\begin{array}{l}\text { Typical }=14-50 \\
\text { Large }=140-500\end{array}$ & 1 & 0.01 & 10's to 100 's & 10 s to 100 s & 10 s to $100 \mathrm{~s}$ & $0.13-0.34$ & $\begin{array}{l}3-5^{\dagger} \\
0.1-0.8^{*}\end{array}$ \\
\hline $\begin{array}{l}\text { Fissure system } \\
\text { length }(\mathrm{km})\end{array}$ & Not given & $\begin{array}{l}\sim 15 \text { wide by } \sim 120 \\
\text { long }\end{array}$ & $\begin{array}{l}\sim 15 \text { wide by } \sim 90 \\
\text { long. }\end{array}$ & 70 & 100 & $>50$ & $\begin{array}{l}\sim 5 \text { wide by } \sim 150 \\
\text { long }\end{array}$ & At least 100 long \\
\hline $\begin{array}{l}\text { Eruption rate } \\
\left(\mathrm{km}^{3} / \mathrm{day} / \mathrm{km} \text { of }\right. \\
\text { fissure) }\end{array}$ & $\begin{array}{l}14 \text { (for fissures } \\
>3 \text { m wide) }\end{array}$ & 1 & 0.0002 & $>1$ & $>1$ & $>1$ & $\begin{array}{l}0.08 \text { (assuming } 4 \\
\text { km active at once) }\end{array}$ & Unknown \\
\hline $\begin{array}{l}\text { Method of } \\
\text { eruption rate } \\
\text { estimate }\end{array}$ & $\begin{array}{l}\text { Numerical model } \\
\text { based on } \\
\text { rheology } \\
\text { arguments. } \\
\text { Requires } \\
\text { turbulent flow. }\end{array}$ & $\begin{array}{l}\text { Based on field } \\
\text { observations } \\
\text { suggesting rapid } \\
\text { emplacement and } \\
\text { Shaw and Swanson's } \\
\text { (1970) model. }\end{array}$ & $\begin{array}{l}\text { Based on field } \\
\text { observations } \\
\text { suggesting rapid } \\
\text { emplacement and } \\
\text { Shaw and Swanson's } \\
\text { (1970) model. }\end{array}$ & $\begin{array}{l}\text { Based on } \\
\text { assumption of } \\
\text { rapid } \\
\text { emplacement } \\
\text { consistent with } \\
\text { field data. }\end{array}$ & $\begin{array}{l}\text { Evaluation of } \\
\text { field data, } \\
\text { chemical } \\
\text { composition } \\
\text { implications with } \\
\text { respect to cooling } \\
\text { calcualtions }\end{array}$ & $\begin{array}{l}\text { Evaluation of } \\
\text { field data, } \\
\text { chemical } \\
\text { composition } \\
\text { implications } \\
\text { with respect to } \\
\text { cooling } \\
\text { calcualtions }\end{array}$ & $\begin{array}{l}\text { Based on model } \\
\text { calculating } \\
\text { cooling times to } \\
\text { form upper crust } \\
\text { on flows. }\end{array}$ & $\begin{array}{l}{ }^{\dagger} \text { Assumes } \\
\text { Maxwell Lake } \\
\text { dike fed flow for } \\
\text { 3-4 years. } \\
\text { *Minimum flux } \\
\text { (advective } \\
\text { transport model). }\end{array}$ \\
\hline Reference(s) & $\begin{array}{l}\text { Shaw and } \\
\text { Swanson (1970) }\end{array}$ & Swanson et al.(1975) & Swanson et al. (1975) & $\begin{array}{l}\text { Reidel and Tolan } \\
\text { (1992) }\end{array}$ & Reidel (2005) & Reidel (1998) & $\begin{array}{l}\text { Self et al. (1997), } \\
\text { Thordarson and } \\
\text { Self (1998) }\end{array}$ & $\begin{array}{l}\text { Petcovic and } \\
\text { Dufek (2005 in } \\
\text { review) } \\
\text { Petcovic and } \\
\text { Grunder (2003) }\end{array}$ \\
\hline
\end{tabular}


fissure segment active for short periods (Table 1). Based on the distribution of the Wapshilla Ridge unit, the dike-fissure system was at least $100 \mathrm{~km}$ long, although the existence of additional dike segments feeding this unit has not yet been determined.

Model results suggest that the Maxwell Lake dike sustained high magma flux for at least several years. The transition from fissure eruption to localized vents during basaltic volcanism is often explained as a function of cooling in narrow portions of dikes coupled with enhanced flow in thicker portions, resulting in isolated, long-lived vents (e.g., Delaney and Pollard 1982; Bruce and Huppert 1990). This process may also explain the presence of wallrock melt zones only along two portions of the Maxwell Lake dike, which experienced higher mass and heat flux as surrounding portions of the dike solidified. Wallrock melt zones adjacent to the Maxwell Lake dike provide evidence for the existence of long-lived point sources playing an important role in flood basalt eruptions.

\subsection{General Conclusions for Emplacement of Columbia River Basalt Group Flows}

Data from studies of flows and dikes indicate a wide range of emplacement rates (Table 1). The estimates for large-volume individual flows range from high eruption rates continuing over timescales as short as one to two months to lower rates sustained over 3-4 years. This should not be surprising and attempts to fit all flows into one model are probably unrealistic. We suggest that the data and interprettations are correct and that some flows are emplaced over long periods of time (like flows of the member of Wapshilla Ridge fed by the Maxwell Lake dike) while others are emplaced over very short intervals (like that estimated for the Sentinel Bluffs Member). In fact, it is probably more realistic to think in terms of a continuous spectrum of emplacement times rather than just the two extremes. The more important question that still remains unanswered is - what mechanism drives the rate at which these basalt flows were erupted? 


\subsection{Road Log}

This Field Trip begins and ends in Moscow, Idaho. Figure 12 shows the route to be followed. Proceed from Moscow, Idaho west along State Route (SR) 8 which becomes SR 270 at the Washington border. Continue through Pullman on SR 270 to junction with US 195. Turn left (south) onto US 195. At intersection with SR 194, turn right. Continue on SR 194 following the signs for Boyer Park and Lower Granite Dam.

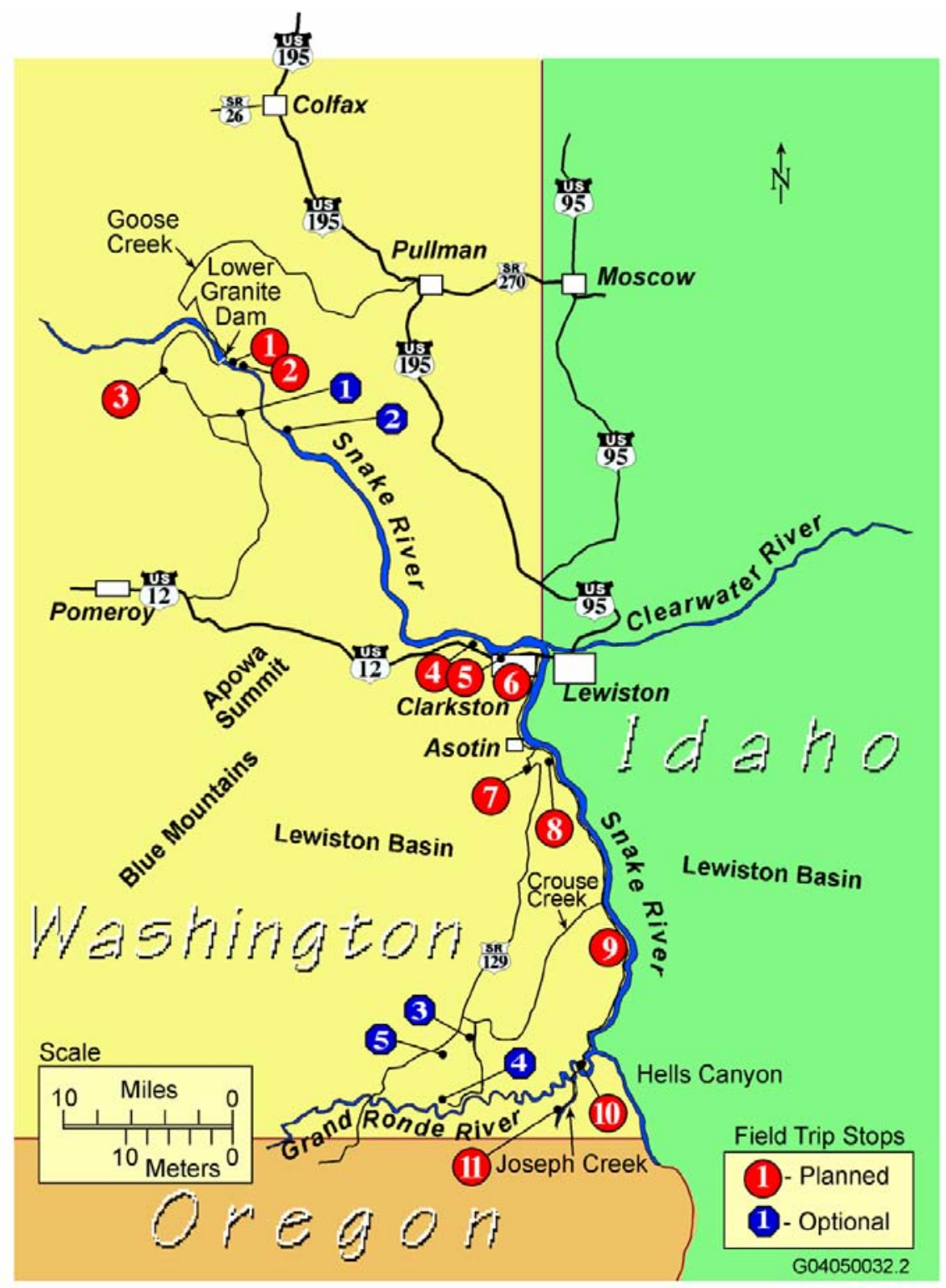

Figure 12. Map Showing Route Followed by Guidebook 
Mileage begins where Almota Road and Goose Creek Road intersect. All distances for the road log are given in miles.

0.0 Intersection of Goose Creek Road. This area of the Columbia River Flood-Basalt Province is noted for its many dike exposures. The first several stops will provide an opportunity to see typical dikes. As we proceed down the Almota grade, and to the first stop, we will be within sight of several dikes, but most are thin and difficult to recognize from a distance.

6.8 Grande Ronde Basalt dike containing xenoliths. This is a low MgO dike that may be of the Umtanum composition. Geochemical analysis of the host basalts suggests that this dike was probably a feeder for the member of Untamum, Grande Ronde Basalt. The xenoliths in this dike are generally smaller and less prominent than those in the Sentinel Bluffs Dike (Stop 2). Finegrained quartz, both clinopyroxene and low-Ca pyroxene (pigeonite), and both colorless and brown, silica-rich glass are the dominant phases in these xenoliths. The mineralogy and petrography of the xenoliths in the dikes, the basalts of the dikes, and granite from nearby Granite Point were examined carefully to learn about the interactions between crustal rocks and basaltic magmas and to gain insights into the type of crust that underlies this part of the CRBG.

11.9 Entrance to Lower Granite Dam. Park vehicles and follow Railroad tracks east to Stop 1.

Stops 1 and 2. - Stop 1 - Typical features of Columbia River Basalt Group Lava Flows. Stop 2 - Xenolith Dike. Stop 2 is $2.3 \mathrm{~km}$ east along the Railroad tracks. As we walk to Stop 2, we will examine typical features of Columbia River Basalt Group flows. These features and a diagram are discussed earlier in this guide.

Stop 2. Xenolith-bearing dikes of the Grande Ronde Basalt. A prominent, 21-meter wide feeder dike with Sentinel Bluffs Member, Grande Ronde Basalt is exposed approximately $2.3 \mathrm{~km}$ upstream of Lower Granite Dam. The presence of internal chilled margins suggests that the dike was subjected to multiple injections of basaltic magma. Several minor dikes of the same composition, each less than a meter wide, are exposed in the outcrops immediately west of the principal dike. Silicic xenoliths are present in the western portion of the primary dike, as well as in a small dike approximately 10 meters west of the main dike.

Textural and Compositional Variations in the Xenoliths. Siliceous xenoliths were present in both the Sentinel Bluffs and Umtanum dikes; however, there were significant differences in the mineralogy of the xenoliths in the two sets of dikes. Quartz, potassium feldspar, plagioclase, pyroxene, \pm rare zircon were present in the xenoliths from the Sentinel Bluffs dikes (B Martin samples AMT 0001 and 0004). As noted previously, fine-grained quartz and pyroxene comprised the xenoliths from the Umtanum dike (AMT 0008). Silica-rich melt was present in all xenoliths. Some xenoliths contain both potassium feldspar and plagioclase; in both cases, the feldspars lie in the middle portion of the compositional range for each solid solution series. Other xenoliths contain only intermediate to sodic plagioclase. Fine-grained, euhedral pyroxene encircles many quartz grains in the xenoliths examined. Similarly, both clino- and orthopyroxene are present in the xenoliths from the Sentinel Bluffs Member dike. Colorless and pale-brown glasses occur throughout the xenoliths. Pyroxenes were associated with the pale-brown glasses. Glass 
compositions were peraluminous and predominantly alkali-rich. The glasses from the Sentinel Bluffs Member dikes formed a trend similar to that seen on calc-alkaline melts; glasses in the xenoliths from the member of Umtanum dike cluster at the $\mathrm{Na}+\mathrm{K}$ corner of the AFM diagram. Quartz and feldspar in xenoliths from the Sentinel Bluffs dike are medium-grained and varied from subangular to rounded. Quartz grains are commonly rounded and were largely intact. Both potassium feldspar and plagioclase showed a range of textures, from largely intact to welldeveloped sieve textures in grains that were permeated with melt. In contrast, the quartz grains in the xenoliths from the Umtanum dike are fine-grained; their textures varied from wholly crystalline to sponge-like with melt-filled interstices.

Interpretation. The siliceous xenoliths in the Sentinel Bluffs and Umtanum dikes display extensive textural evidence for partial melting (anatexis) following their incorporation into the basaltic magmas. The anatectic melts are peraluminous and largely trondjemitic and granitic in composition. Mineralogical differences between the xenoliths in the two dikes probably reflects variations in the crust sampled by the intruding magma. The presence of quartz and both plagioclase and potassium feldspar in the Sentinel Bluffs Member-hosted xenoliths suggest that the host magma intruded granitic crustal material during its ascent to the surface. This is further supported by the similarity between the plagioclase compositions of the xenoliths and the nearby granodiorite of Granite Point, approximately $7 \mathrm{~km}$ to the southeast. In contrast, fine-grained quartz is the primary mineral in the Umtanum-hosted xenoliths suggest that the host magma may have sampled sedimentary crustal material. The distribution of glass compositions in the normative quartz-albite-orthoclase ternary implies that the xenoliths underwent partial melting under a range of water saturation conditions. Clustering of the glasses in the xenoliths from the Umtanum dike indicates that anatexis of these samples occurred close to the Earth's surface. On the other hand, the spread of glass compositions adjacent to the positions of the 1 and $2 \mathrm{~kb}$ ternary minima and 5 and $10 \mathrm{~kb}$ ternary eutectics in the granitic system suggests that the Sentinel Bluffs magma sampled a more extensive section of the crust over a range of depths.

12.9 Cross dam and follow road to right.

14.5 Climbing up Mayview Grade-Casey Creek Road. First exposure of Roza dike. There are three Roza dike exposures. We will stop at the best exposure to examine the characteristics of a Roza dike.

14.7 Exposure of Roza dike.

14.9 Exposure of Roza dike.

15.4 Lynn Gulch Road.

16.9 Roza dike exposure. Several dikes are exposed in this road cut. 
18.0 Stop 3. Mayview Roza Dike. A single, 3-meter wide, plagioclase phyric Roza dike is exposed along the southwest side of Casey Creek Road. The dike is cutting through the oxidized flow top and base of two Grande Ronde N2 flows. The physical features of this dike are typical for many Columbia River Basalt dikes. Prominent horizontal columnar jointing develops during cooling in many dikes, facilitating the recognition of dikes in the field. A $1 \mathrm{~cm}$ thick glassy zone with minor palagonitized surfaces marks both margins of the dike. The glassy margin grades quickly into the crystalline interior of the dike. Marginal glass has slightly higher concentrations of incompatible and lower concentrations of compatible elements compared to the dike interior. A second plagioclase phyric meter-wide dike is present in the road cut approximately 30 meters to the northwest (down the road). Geochemical analysis suggests that the main dike was a feeder for Roza II ( $\mathrm{P}_{2} \mathrm{O}_{5}, 0.70-0.73$ wt. \%; Cr, 23-29 ppm) while the smaller dike has a Roza III composition $\left(\mathrm{P}_{2} \mathrm{O}_{5}, 0.65-0.67\right.$ wt. \%; Cr, $42-48$ ppm) (Martin 1989). Approximately $3 \mathrm{~km}$ to the south along Casey Creek Road (208 meters above), a thin layer of tephra occurs between two Roza flows.

In addition to the Roza, this area is the eastern-most exposures of the Frenchman Springs Member. There are two flows exposed here with a thin saprolite/soil zone that separates them from the N2 Grande Ronde Basalt flows exposed at this stop. The Frenchman Springs Member thickens to the west.

22.0 Turn left on Tramway Road for optional Stop 1.

Optional Stop 1. Priest Rapids Member and Snake River overlook. Follow road to white stile and quarry. The quarry is in the Lolo flow of the Priest Rapids Member, the youngest basalt of the Wanapum Basalt. This stop provides an excellent view of the Grande Ronde as well as an opportunity to see the Priest Rapids Member.

Return to intersection of Kirby-Mayfield Road and Tramway Road.

24.3 Kirby-Mayview Road intersection. Turn left onto Kirby-Mayview Road toward Pomeroy, Washington.

39.4 Intersection with US 12. Turn left toward Lewiston-Clarkston.

43.6 Alpowa Summit. Rest stop. From here on you will be descending into the Lewiston Basin.

60.2 Stop 4. Intracanyon Elephant Mountain Member and Pomona Member, Saddle Mountains

Basalt. Pull off in large parking area and walk back to exposure. These are intracanyon lavas of the 10.5 Ma Elephant Mountain Member and the 12 Ma Pomona Member. The flows overlie nearly horizontal flows of the N2 GRB (15.5 Ma). Swanson et al. (1980) first recognized intracanyon basalt in the area. The main vent for the Elephant Mountain Member is exposed to the south while the dike for the Pomona is exposed in the Orofino area of the Clearwater Embayment, approximately $60 \mathrm{~km}$ east of Lewsiton, Idaho. The areal extent of these flows is based on mapping remnants of the members from the Lewiston Basin to the Pasco Basin and west. The Pomona Member consists of $760 \mathrm{~km}^{3}$ and covers 20,550 km² ; the Elephant Mountain Member consists of $440 \mathrm{~km}^{3}$ and covers 13,450 km² (Tolan et al. 1989). 
The Pomona Member is one of the more MgO rich (6.5 wt \%) units of the CRBG. The Elephant Mountain Member is less MgO rich and its composition resembles Frenchman Springs lavas of the Wanapum Basalt; however, Saddle Mountains Basalt flows typically are the most evolved basalts of the CRBG.

62.2 Stop 5. Intracanyon Lower Monumental Member. The lower Monumental Member is the youngest lava of the Columbia River Basalt Group, having erupted about 5.5 Ma. It also has one of the smallest volumes $\left(15 \mathrm{~km}^{3}\right)$; it covers only $430 \mathrm{~km}^{2}$ and is confined exclusively to the present Snake River canyon. It has not been found any farther west than Lower Monumental Dam. The Lower Monumental Member has intermediate MgO (approx 4.4 wt \%).

End of Road Log for Day One.

Optional Stop 2. Granite Point. Proceed into Clarkston on US 12. At the left turn on Red Wolff Road (traffic light) for the Port of Wilma and bridge to north side of Snake River. Turn left (west) on SR 193 which is Wawawai Road. Follow SR 193 for about 20 miles. Granite Point is an exposure of granodiorite. See discussion of Stop 2.

Day Two. Mileage will begin at Asotin Creek on the north end of the City of Asotin.

\section{Stop 6. Discussion of the Geology of the Clearwater Embayment and Lewiston Basin.}

The eastern portion of the Columbia River Flood-Basalt Province consists of a series of 'embayments' in the Bitter Root Mountains of Idaho. The Lewiston Basin is a fault-bounded basin along the Idaho-Washington-Oregon boundaries in the Clearwater embayment. The following discussion of the geologic structures is an abstract that was presented at the 2003 Geological Society of America Meeting in Seattle by Dean L. Garwood, John H. Bush, John D. Kauffman, and Thomas E. Jones at the University of Idaho and the Idaho Geological Survey. Dean L. Garwood, John H. Bush, and John D. Kauffman have been working in the Lewiston Basin and Clearwater Embayment for many years and will discuss some of their findings.

General Structure of the Clearwater Embayment. (Garwood et al. 2003: Geological Society of America, 2003 Annual Meeting, Seattle, Washington, United States)

"The Clearwater embayment is located along the eastern margin of the Columbia Plateau, where a large area $\left(64 \mathrm{~km}^{2}\right)$ of the Columbia River Basalt Group (CRBG) is exposed. Several major basins and a few folds and reverse faults have previously been noted, although most workers described the area as essentially horizontal CRBG flows with steep normal faults and minor folds forming the basin boundaries. In the past decade, mapping has identified additional basins and determined that folding is more common than faulting. Several linear structures, each previously described or illustrated as normal faults, were examined and shown to be primarily asymmetrical folds. Over 40 asymmetrical folds with minor topographic expression have been mapped that are typically low-amplitude, non-cylindrical folds with narrow anticlinal ridges separated by broad, essentially flat or gently folded synclinal valleys. Where faulting is present, movement has been determined to be reverse or strike slip. Larger folds that are significant topographic features 
include the Limekiln structure or Waha front, Lewiston Hill, and White Bird Hill. The Waha front is a 35-km long northeast-trending monocline that forms the southern boundary of the Lewiston Basin. On the southwestern end, the monocline contains strike-slip faults both parallel and oblique to its axis. On the northeastern end, the monocline has only minor associated faults. The Lewiston Hill borders the Lewiston Basin on the north and is primarily an east-west trending asymmetrical anticline with a steep southern limb and associated reverse faults. The White Bird Hill in the southern part of the embayment is a large asymmetrical anticline, which has a steep northwestern limb near Grangeville that changes symmetry to a steep southeastern limb near White Bird. On White Bird grade the anticline is crossed by a strike-slip fault that produces over 50 meters of apparent vertical offset. These three features are similar in overall morphology to large Yakima-style folds in west-central Washington. Additional mapping in the embayment is needed, but enough work has been completed to show that the structural setting for the CRBG is not adequately portrayed in the literature.”

Age of the Lewiston Basin. The Lewiston Basin is located in the Chief Joseph dike swarm. Work has shown that the basin began growing by Imnaha-Grande Ronde time (Camp 1976; Reidel 1982; Garwood 2001) and continued to grow into at least the Pliocene and perhaps is still growing.

Proceed south from Clarkston, Washington on SR 129. Mileage begins at the bridge over Asotin Creek at the north edge of Asotin.

0.0 Asotin Creek at the north end of the City of Asotin, Washington.

0.3 Asotin Grade. Turn right and follow SR 129 toward Enterprise, Oregon.

3.1 Stop 7. Invasive Asotin Member of the Saddle Mountains Basalt. At this locality, the Asotin Member has flowed over a thick sedimentary sequence of the Ellensburg Formation equivalent (Latah interbed). The sediment was wet and poorly consolidated so the lava was able to burrow into the sediment. This process is very common in the CRBG where there are thick sediments. The process was first described by Byerly and Swanson (1978). One of the key elements in identifying an invasive basalt flow is sediment mixed with the basalt, especially in the flow top. Invasive basalts reached an extreme along the Oregon coast where the flows burrowed for miles through Eocene sediments. At places, the basalts locally were able to reach the surface forming rootless dikes.

Turn around and proceed back down Asotin Grade to the intersection with River Road.

0.0 Optional Stops 3, 4, and 5. Puffer Butte Volcano and Dike. Instead of turning around at Stop 7, proceed south on SR 129 to Fields Spring State Park. Fields Springs State Park is developed on Puffer Butte (Optional Stop 5) which is a volcano for the Umatilla Member. The Umatilla Member has been described by Reidel (1998). The Umatilla Member consists of two flows: the Umatilla flow, which is the oldest, and the Sillusi flow. Puffer Butte is composed of the younger Sillusi flow. The volcano is fed by a dike which can be seen at Optional Stop 4. There are trails around the park that allow you to see exposures of the vent material that makes up the volcano. 
To reach Optional Stops 3 and 4, retrace route on SR 129 to Montgomery Ridge Road. This is approximately 2 miles. Turn right (east) on Montgomery Ridge Road and follow it for approximately one mile to Schumaker Road. Turn right (south) on Schumake Road and follow it to the edge of the Grande Ronde River Canyon. This is Optional Stop 3. The stratigraphy here (Reidel et al., 1992) is from the top down: Basalt of Ten Mile Creek (Weissenfel Ridge Member), Basalt of Schumaker Creek (Wanapum Basalt), Basalt of Dodge (Eckler Mountain Member) which has the saprolite developed on it, Basalt of Meyer Ridge (R2 Grande Ronde Basalt), R2 Grande Ronde Basalt undivided, N1 Grande Ronde Basalt undivided and R1 Grande Ronde Basalt undivided.

To reach Stop 4, Umatilla Dike (commonly called the Tunnel dike), continue down Schumaker grade to the river, bear right (west and follow the road until it ends. The Umatilla dike forms a resistant feature that forced the settlers who made the old stagecoach route to cut a tunnel through. This dike has good selvage zones exposed on either side. The composition is exclusively that of the Sillusi flow although Reidel et al. (1992) and Reidel (1998) feel that the original fracture was used by the Umatilla flow initially.

Return to Stop 7 and follow mileage.

5.9 River Road, turn right.

6.3 Stop 8. Ancestral channel of the Clearwater River. On the south side of the river are a series of unusual looking lava flows. These are flows of the Pomona and Elephant Mountain members exposed in a cross section of the ancestral Clearwater River. The channel is well exposed on the south side of the exposure where the Saddle Mountains Basalt overlies N2 Grande Ronde Basalt.

20.7 Stop 9. Basement Rock. This locality provides an opportunity to examine some of the accreted terrain rocks that underlie the Columbia River Basalt. This exposure is of the Triassic Wild Sheep Creek Formation. Mapping of the pre-CRBG rocks has shown that the topography of this region was a rugged, mountainous one. The nature of the topography can be imagined by looking at the area surrounding this stop.

30.1 Stop 10. Contact between the Imnaha Basalt and the Grande Ronde Basalt. The differences between the Grande Ronde Basalt and the Imnaha Basalt are very apparent at this locality. Although the compositions are very different, this contact suggests very little time elapsed between eruptions. Paleomagnetic polarities for the Imnaha Basalt are normal but the overlying Grande Ronde Basalt is transitional in this flow and become reversed above (R1 
Magnetostratigraphic Unit [MSU]). The type section for the Grande Ronde Basalt is a few miles down the road where the R1, N1, and R2 MSUs are present. The younger N2 is farther north in the Lewiston Basin and beyond.

33.7 Lake Bonneville flood gravels.

35.6 Stop 11. Dike-vent complex of the Joseph Creek flow, Teepee Butte Member. This stop affords the opportunity to see one of the best preserved vent/dike complexes for the CRBG. This complex has been described by Reidel and Tolan (1992) so only a brief description will be given in this guide.

The Joseph Creek dike is typical of other dikes in the Chief Joseph dike swarm. About $3 \mathrm{~km}$ of a nearly continuous, basalt dike is exposed in Joseph Canyon. For $300 \mathrm{~m}$ on the south side of Joseph Creek, however, the dike is a series of en echelon segments that trend from N16-18 $\mathrm{W}$ to nearly north-south.

On the north side of Joseph Canyon, the dike can be traced from just above Joseph Creek into a vent complex. The lower portion of the dike (where it cuts the Imnaha Basalt) is relatively narrow, averaging about $7 \mathrm{~m}$ in width. Here the dike displays well-developed horizontal columnar joints (column diameter $<0.3 \mathrm{~m}$ ) and has a fine-grained texture. The dike margins are marked by a narrow, 1 to $5 \mathrm{~cm}$-wide, glassy selvage accompanied by several dike-parallel vesicle layers. Narrow vesicular zones $(<1 \mathrm{~cm})$ occupy the center the dike.

The dike passes through three flows of the Grande Ronde Basalt, two belonging to the Buckhorn Springs unit and the Limekiln Rapids flow. The dike widens from $40 \mathrm{~m}$ at the base of the Limekiln Rapids flow (Teepee Butte Member) to more than $150 \mathrm{~m}$ at the paleoground surface. Outwardly, the jointing pattern of the basalt filling this part of the fissure resembles a normal blocky to columnar pattern, typical of basalt flows in the area. Also, the texture coarsens from medium-grained near the margins to nearly diabasic in the central portion which we interpret to be a lava pond.

Dike composition is relatively uniform but evolved compositions occur in the selvage zone. This composition probably represents the first erupted lava. No flows with this composition have been found in the Grande Ronde Basalt suggesting that it characterizes only a minor volume of lava.

Collapse breccia. A breccia deposit lies between the eastern margin of the lava pond and fissure wall. The breccia is composed of angular clasts, ranging from several centimeters to $>1 \mathrm{~m}$, derived from both the Limekiln Rapids flow which forms the walls of the fissure, and tephra.

Vent Ramparts. The vent ramparts are asymmetrical with respect to the types of deposits present. The eastern rampart is nearly $30 \mathrm{~m}$ high and composed of interbedded tephra and lava flows, whereas the western rampart is about $22 \mathrm{~m}$ high and composed wholly of lava flows.

Tephra. Adjacent to the fissure, the eastern rampart is composed of tephra separated by relatively thin pahoehoe flows. Tephra ranges from ash- to bomb-size, with the larger clasts 
(bombs) proximal to the vent. The tephra deposits are moderately indurated, probably resulting from some incipient welding as well as minor alteration of the glassy ash to clay by groundwater. The most notable aspect of these deposits is the abundance of coarse ash- to lapilli-size Pele's tears; this is the first report of such pyroclasts at a Columbia River Basalt Group vent (Reidel and Tolan 1990).

Pele's tears and bombs occur throughout the eastern rampart but are concentrated at three different levels, with the thickest accumulation forming the upper-most deposit. Pele's tears range from $1 \mathrm{~mm}$ to $>1 \mathrm{~cm}$ in size; fragments are black, smooth-skinned, and display a range of attenuated shapes including spheres, ovoids, "dumbbells," and the classic pear shapes of Hawaiian Pele's tears. The Pele's tears are typically unaltered glass that stand in relief on red oxidized weathered surfaces, giving natural exposures a "pebbly" look. The smooth exterior surface of the Pele's tears covers an interior of highly vesiculated glass. The distal extent of these tephra deposits is $300 \mathrm{~m}$ east of the vent.

Scattered ribbon and cow-dung bombs are found within the tephra deposits, and their relative size and number increase with proximity to the vent. Ribbon bombs typically have two forms. One type is a cylindrical ribbon bomb that commonly occurs as broken, rod-shaped segments. The second type was still plastic when striking the ground and resembles a coil of flattened rope. The second type is generally preserved intact, but the cylindrical ribbon bombs are often broken, apparently too fragile to survive the impact. Less common are cow-dung bombs which have a flattened, disk-like shape.

Pahoehoe Flows. Two types of pahoehoe flows are recognized in the vent ramparts: spatter-fed pahoehoe and shelly pahoehoe. They are interbedded with tephra in the east rampart but form the entire western rampart.

Spatter-fed pahoehoe flows are massive to blocky jointed and typically display a distinctive "flow-banded" appearance. As the name suggests, these flows formed when molten spatter, created by lava fountaining, fell back to the ground and collected into flows that moved away from the vent.

The shelly pahoehoe flows also have a distinct appearance, typically occurring as either a series of thin and discontinuous vesicular layers, a series of complexly folded and broken layers, or a combination of both. Their internal structures are identical to those seen in the sheet-flood variety of shelly pahoehoe produced by some Hawaiian volcanoes (Swanson 1973; Wentworth and Macdonald 1953).

Extensional Cracks. The lower $10 \mathrm{~m}$ of the east rampart adjacent to the fissure is tilted several degrees toward the lava pond and is cut by numerous extension cracks. The extension cracks penetrate only the lower two-thirds of the rampart; the largest is $0.3 \mathrm{~m}$ wide. These extension cracks opened prior to the last episode of fountaining and were filled by tephra. We interpret the tilting and extensional cracks to be a later fissure-widening event that occurred when the initial collapse breccia deposits slumped into the fissure and tilted the rampart. 
Growth and Development of the Joseph Creek Vent. Joseph Creek vent deposits are indicative of a Hawaiian-type eruption. Fountaining and effusion of lava were important parts of the eruptive process. Thick pyroclastic deposits are found only in the eastern rampart and deposition was probably influenced by a prevailing westerly wind direction. However, the west side is downslope; any tephra deposited to the west could have been either rafted or bulldozed and swept away by erupting lava.

Evidence suggests that eruptive activity waxed and waned at the vent locality. At least four major episodes of lava fountaining are preserved at the vent, one in the collapse breccia and three in the eastern rampart. Each episode erupted thin pahoehoe flows accompanied by tephra mainly composed of Pele's tears. The tephra deposits and spatter-fed pahoehoe flows offer direct evidence of repeated fountaining.

The final event at the Joseph Creek vent was the formation of a lava pond. The lava pond stands at the same level as the ground surface during Joseph Creek time, yet, the unique chemical composition of the lava pond has not been found in vent deposits or basalt flows of the R1 MSU. We infer that no lava flows were erupted from the pond after the change in composition.

Solidification of the lava pond within the Joseph Creek fissure marked the end of Joseph Creek volcanism at this locality. The surface of the lava pond had solidified and stabilized prior to emplacement of the Pruitt Draw flow so that a period of several years separated these eruptions. The Pruitt Draw flow only partly inundated the Joseph Creek vent; it filled the low area between the two ramparts and caused minor deformation of the eastern rampart.

End of Road Log 


\subsection{References}

Bingham JW and MJ Grolier. 1966. The Yakima Basalt and Ellensburg Formation of South-Central Washington. U.S. Geological Survey Bulletin 1224-G, p. 1-15.

Bingham JW and KL Walters. 1965. Stratigraphy of the upper part of the Yakima Basalt in Whitman and eastern Franklin Counties, Washington. U.S. Geological Survey Professional Paper 525-C, p. C87-C90.

Bruce P and H Huppert. 1990. "Solidification and melting along dykes by laminar flow of basaltic magma.” In M Ryan, ed., Magma transport and storage, New York, John Wiley and Sons, p. 87-102.

Byerly GR and DA Swanson. 1978. "Invasive Columbia River Basalt flows along the northwest margin of the Columbia Plateau, North-Central Washington.” Geological Society of America Abstracts with Program, vol. 10, no. 3, p. A98.

Camp VE. 1976. Petrochemical stratigraphy and structure of the Columbia River basalt, Lewiston basin area, Idaho-Washington. Ph.D. Thesis, Pullman, Washington State University, 201 p.

Camp VE and ME Ross. 2004. "Mantle dynamics and the genesis of mafic magmatism in the Pacific Northwest.” Journal of Geophysical Research, v. 109, B08204, doi: 10.1029/2003JB002838.

Camp, VE, ME Ross, and WE Hanson. 2003. "Genesis of flood basalts and Basin and Range volcanic rocks from Steens Mountain to the Malheur River Gorge, Oregon.” Geological Society of America Bulletin, v. 115, p. 105-128.

Campbell NP. 1989. "Structural and Stratigraphic Interpretation of the Rocks Under the Yakima Fold Belt Based on Recent Surface Mapping and Well Data.” In, SP Reidel and PR Hooper, eds., Volcanism and Tectonism in the Columbia River Flood-Basalt Province. Geological Society of America Special Paper 239, p. 209-222.

Davis GA. 1981. "Late Cenozoic Tectonics of the Pacific Northwest with Special Reference to the Columbia Plateau.” Final Safety Analysis Report, WNP-2, Appendix 2.5 N, Washington Public Power Supply System, Richland, Washington.

Delaney PT and DD Pollard. 1982. "Solidification of basaltic magma during flow in a dike." American Journal of Science, v. 282, p. 856-885.

Diery HD. 1967. Stratigraphy and Structure of the Yakima Canyon Between Roza Gap and Kittitas Valley, Central Washington. M.S. Thesis, Seattle, University of Washington, 117 p.

Department of Energy, 1988. Site Characterization Plan Reference Repository Location, Hanford Site, Washington, DOE/RW-0164, Vol. 2, Washington, D.C.

Fecht KR, SP Reidel, and AM Tallman. 1982. "Evolution of the Columbia River System on the Columbia Plateau of Washington State from Miocene to present." Geological Society of America Abstracts with Program, v. 14, no. 4, p. 163. 
Fecht KR, SP Reidel, and AM Tallman. 1987. "Paleodrainage of the Columbia River System on the Columbia Plateau of Washington State-A Summary.” In JE Schuster, ed., Selected Papers on the Geology of Washington, Washington Division of Geology and Earth Resources Bulletin 77, p 219-248.

Fenneman NM. 1931. Physiography of the western United States: New York, McGraw-Hill Book Co., New York, 534 p.

Fialko YA and AM Rubin. 1999. "Thermal and mechanical aspects of magma emplacement in giant dike swarms.” Journal of Geophysical Research, v. 104 p. 23,033-23,049.

Frizzell VA, Jr., RW Tabor, DB Booth, KM Ort, and RB Waitt, Jr. 1984. Preliminary geologic map of the Snoqualime Pass 1:100,000 quadrangle, Washington. U.S. Geological Survey Open-File Report 84-693, 43 p., 1 plate, scale 1:100,000.

Garwood DL. 2001. Bedrock geology of the Lewiston Orchards North and Lapwai 7-1/2-minute quadrangles, Nez Perce County, Idaho. M.S. Thesis, Moscow, University of Idaho, 62 p.

Garwood DL, JH Bush, JD Kaufmann, and TE Jones. 2003. "New interpretations of structures in the Columbia River Basalt Group of the Clearwater Embayment, Idaho.” Geological Society of America Abstracts with Program, vol. 35, no. 6, p. 551.

Grolier MJ and JW Bingham. 1971. Geologic map and sections of parts of Grant, Adams, and Franklin Counties, Washington. U.S. Geological Survey Miscellaneous Geologic Investigations series Map I-589, scale 1:62,500.

Ho AM and KV Cashman. 1997. "Temperature constraints on the Ginkgo Flow of the Columbia River Basalt Group.” Geology, v. 25, p. 403-406.

Hon K, J Kauahikaua, R Denlinger, and K MacKay. 1994. "Emplacement and inflation of pahoehoe sheet flows: Observations and measurements of active lava flows on Kiluaea Volcano, Hawaii." Geological Society of America Bulletin, v. 106, p. 351-370.

Hooper PR. 2000. "Chemical discrimination of Columbia River basalt flows.” Geochemistry Geophysics Geosystems, v. 1, doi: 10.1029/2000GC000040.

Hooper PR, GB Binger, and KR Lees. 2002. “Ages of the Steens and Columbia River flood basalts and their relationship to extension-related calc-alkaline volcanism in eastern Oregon.” Geological Society of America Bulletin, v. 114, p. 43-50.

Jarchow CM. 1991. Investigations of Magmatic Underplating Beneath the Northwestern Basin and Range Province, and Seismic Data Acquisition and Tectonic Problems of the Columbia Plateau, Washington, and the Nature of the Mohorovic'ic' Discontinuity Worldwide. Ph.D. Thesis, Stanford, California, Stanford University, 271 p.

Kienle CF, RD Bentley, and JL Anderson. 1977. "Geologic Reconnaissance of the Cle Elum-Wallula Lineament and Related Structures.” Preliminary Safety Analysis Report, Amendment 23, Vol. 2A, Subappendix 2R D, Shannon and Wilson, Inc. for Washington Public Power Supply System, Richland, Washington. 
Keszthelyi L and S Self. 1998. "Some physical requirements for the emplacement of long basaltic lava flows.” Journal of Geophysical Research, v. 103, p. 27,447-27,464.

Lefevbre RH. 1966. Variations of flood basalts of the Columbia River Plateau, central Washington. Ph.D. Thesis, Evanston, Illinois, Northwestern University, 211 p.

Lefevbre RH. 1970. “Columbia River Basalt of the Grand Coulee area.” In EH Gilmour, and D Stradling, eds., Proceedings of the Second Columbia River Basalt Symposium: Cheney, Washington, Eastern Washington State College Press, p. 1-38.

Mackin JH. 1961. A stratigraphic section in the Yakima Basalt and Ellensburg Formation in south-central Washington. Washington Division of Mines and Geology Reports of Investigations 19, 45 p.

Martin BS. 1991. Geochemical variations within the Roza Member, Wanapum Basalt, Columbia River Basalt Group: Implications for the magmatic processes affecting continental flood basalts. Ph.D. Thesis, Amherst, University of Massachusetts, 513 p.

Martin BS. 1989. "The Roza Member, Columbia River Basalt Group; Chemical stratigraphy and flow distribution.” In SP Reidel and PR Hooper, eds., Volcanism and tectonism in the Columbia River flood-basalt province, Geological Society of America, Special Paper 239, p. 85-104

Mangan MT, TL Wright, DA Swanson, and GR Byerly. 1986. "Regional correlation of Grande Ronde Basalt flows, Columbia River Basalt Group, Washington, Oregon, and Idaho.” Geological Society of America Bulletin, v. 97, p. 1300-1318.

Meints JP. 1986. Statistical Characterization of Fractures in the Museum and Rocky Coulee Flows of the Grande Ronde Formation, Columbia River Basalts. M.S. Thesis, Pullman, Washington State University, $238 \mathrm{p}$.

Petcovic HL and JD Dufek. 2005. "Modeling magma flow and cooling in dikes: Implications for emplacement of Columbia River flood basalts.” Journal of Geophysical Research, in review.

Petcovic HL and AL Grunder. 2003. "Textural and thermal history of partial melting in tonalitic wallrock at the margin of a basalt dike, Wallowa Mountains, Oregon.” Journal of Petrology, v. 44, p. 2287-2312.

Price SA. 1977. An evaluation of dike-flow correlations indicated by geochemistry, Chief Joseph swarm, Columbia River Basalt. Ph.D. Thesis, Moscow, University of Idaho, 320 p.

Raisz E. 1945. “The Olympic-Wallowa-Lineament.” American Journal of Science, v. 243-A, p. 479485.

Reidel SP. 2005. “A lava flow without a source: The Cohasset Flow and its compositional components, Sentinel Bluffs Member, Columbia River Basalt Group.” Journal of Geology, v. 113, p. 1-21.

Reidel SP. 1998. "Emplacement of Columbia River flood basalt.” Journal of Geophysical Research, v. 103, p. 27,393-27,410. 
Reidel SP. 1982. "Stratigraphy of the Grande Ronde Basalt, Columbia River Basalt Group, from the lower Salmon River and northern Hells Canyon area, Idaho, Oregon and Washington.” In B Bonnichsen and RM Breckenridge, eds., Cenozoic Geology of Idaho. Idaho Bureau of Mines and Geology Bulletin 26, p. 77-101.

Reidel SP and NP Campbell. 1989. "Structure of the Yakima Fold Belt, Central Washington.” In, NL Joseph et al., eds., Geologic Guidebook for Washington and Adjacent Areas. Washington Division of Geology and Earth Resources Information Circular 86, p. 275-303.

Reidel SP and KR Fecht. 1987. "The Huntzinger flow: Evidence of surface mixing of the Columbia River Basalt and its petrogenetic implication.” Geological Society of America Bulletin, v. 98, p. 664-677.

Reidel SP and PR Hooper, eds. 1989. Volcanism and tectonism in the Columbia River flood-basalt province. Geological Society of America Special Paper 239, 386 p.

Reidel SP and TL Tolan. 1992. "Eruption and emplacement of flood basalt: An example from the largevolume Teepee Butte Member, Columbia River Basalt Group.” Geological Society of America Bulletin, v. 104, p. $1650-1671$.

Reidel SP and TL Tolan. 1990. "Evidence for Hawaiian-style eruptions in huge volume basalt flows from the Columbia River flood-basalt province.” Geological Society of America Abstracts with Programs, v. 22, no. 7, p. 351.

Reidel SP, KR Fecht, KA Lindsey, and NP Campbell. 1994. "Late Cenozoic Structure and Stratigraphy of South-Central Washington.” In R Lasmanis and ES Cheney, eds., Regional Geology of Washington State. Washington Division of Geology and Earth Resources Bulletin 80, p. 159-180.

Reidel SP, PR Hooper, GD Webster, and VE Camp. 1992. Geologic Map of Southeast Asotin County, Washington. Washington Division of Geology and Earth Resources Geologic Map GM-40, scale $1: 48,000$

Reidel SP, TL Tolan, PR Hooper, MH Beeson, KR Fecht, RD Bentley, and JL Anderson. 1989a. “The Grande Ronde Basalt, Columbia River Basalt Group: Stratigraphic descriptions and correlations in Washington, Oregon, and Idaho.” In SP Reidel and PR Hooper, eds., Volcanism and tectonism in the Columbia River flood-basalt province. Geological Society of America Special Paper 239, p. 21-53.

Reidel SP, KR Fecht, MC Hagood, and TL Tolan. 1989b. "The Geologic Evolution of the Central Columbia Plateau.” In SP Reidel and PR Hooper, eds., Volcanism and Tectonism in the Columbia River Flood-Basalt Province. Geological Society of America Special Paper 239, p. 247-264.

Reidel SP, PE Long, CW Myers, and J Mase. 1982. "New evidence for greater than $3.2 \mathrm{~km}$ of Columbia River basalt beneath the central Columbia Plateau [abs.].” EOS (Transactions, American Geophysical Union), v. 63, p. 173.

Ross ME. 1983. "Chemical and mineralogical variations within four dikes of the Columbia River Basalt Group, southeastern Columbia Plateau.” Geological Society of America Bulletin, v. 94, p. 1117-1126.

Saltus RW. 1991. Gravity and Heat Flow constraints on Cenozoic tectonics of the western United States Cordillera. Ph. D. Thesis, Stanford, California, Stanford University, 244 p. 
Schmincke HU. 1967. "Flow directions in Columbia River Basalt flows and paleocurrents of interbedded sedimentary rocks, south-central Washington.” Geologische Rundschau, v. 56, p. 992-1020.

Self S, T Thordarson, L Keszthelyi, GPL Walker, K Hon, MT Murphy, PE Long, and S Finnemore. 1996. "A new model for the emplacement of Columbia River basalts as large, inflated pahoehoe lava flow fields.” Geophysical Research Letters, v. 23, p. 2689-2692.

Self S, T Thordarson, and L Keszthelyi. 1997. "Emplacement of continental flood basalt lava flows." In JJ Mahoney and MF Coffin, eds., Large Igneous Provinces: Continental, Oceanic, and planetary flood volcanism. American Geophysical Union Geophysical Monograph 100, p. 381-410.

Shaw HR and DA Swanson. 1970. "Eruption and flow rates of flood basalts.” In EH Gilmour and D Stradling, eds., Proceedings of the second Columbia River Basalt symposium. Cheney, Washington, Eastern Washington State College Press, p. 271-299.

Smith GA. 1988. "Neogene Synvolcanic and Syntectonic Sedimentation in Central Washington.” Geological Society of America Bulletin, v. 100, p. 1479-1492.

Smith GA, BN Bjornstad, and KR Fecht. 1989. "Neogene terrestrial sedimentation on and adjacent to the Columbia Plateau: Washington, Oregon and Idaho.” In SP Reidel and PR Hooper, eds., Volcanism and tectonism in the Columbia River flood-basalt province. Geological Society of America Special Paper 239, p. 187-198.

Spry A. 1962. “The Origin of Columnar Jointing Particularly in Basalt Flows.” Geological Society of Australia Journal, v. 8, p. 191-216.

Stoffel KL, NL Joseph, SZ Waggoner, CW Gulick, MA Korosec, and BB Bunning. 1991. Geologic Map of Washington - Northeast Quadrant. Washington Division of Geology and Earth Resources Geologic Map GM-39, scale 1:250,000.

Swanson DA. 1973. "Pahoehoe flows from the 1969-1971 Mauna Ulu eruption, Kilauea Volcano, Hawaii.” Geological Society of America Bulletin, v. 84, p. 615-626.

Swanson DA and TL Wright. 1981. "Guide to Geologic Field Trip Between Lewiston, Idaho and Kimberly, Oregon, Emphasizing the Columbia River Basalt Group.” In DA Johnston and J DonnellyNolan, eds., Guides to Some Volcanic Terrains in Washington, Idaho, Oregon, and Northern California, U.S. Geological Survey Circular 838, p. 1-28.

Swanson DA, TL Wright, VE Camp, JN Gardner, RT Helz, SM Price, SP Reidel, and ME Ross. 1980. Reconnaissance geologic map of the Columbia River Basalt Group, Pullman and Walla Walla Quadrangles, southeast Washington and adjacent Idaho: U.S. Geological Survey Miscellaneous Investigations Series Map I-1139, scale 1:250,000.

Swanson DA, TL Wright, PR Hooper, and RD Bentley. 1979. Revisions in stratigraphic nomenclature of the Columbia River Basalt Group. U.S. Geological Survey Bulletin 1457-G, 59 p.

Swanson DA, TL Wright, and RT Helz. 1975. "Linear vent systems and estimated rates of magma production and eruption of the Yakima Basalt on the Columbia Plateau." American Journal of Science, v. 275, p. 877-905. 
Tabor RW, VA Frizzell, Jr., JA Vance, and CW Naeser. 1984. “Ages and Stratigraphy of Lower and Middle Tertiary Sedimentary and Volcanic Rocks of the Central Cascades, Washington--Application to the Tectonic History of the Straight Creek Fault.” Geological Society of America Bulletin, v. 95, p. 2644.

Taubeneck WH. 1998. "Control of strike and dip of dikes of Columbia River Basalt Group (CRBG) by major joint sets in granitic rocks or Wallowa Batholith (WB), Northeast Oregon.” Geological Society of America Abstracts with Programs, v. 30, no. 5, p. 68.

Taubeneck WH. 1990. "Significant discoveries during 1989 involving dikes of Columbia River Basalt in pre-Tertiary rocks in eastern Oregon and western Idaho." Geological Society of America Abstracts with Programs, v. 22, no. 3, p. 88.

Taubeneck WH. 1989. "Recently defined axes of eruption in northeast Oregon in the southernmost part of the Chief Joseph dike swarm of Columbia River Basalt (CRB) Oregon, Idaho, and Washington.” Geological Society of America Abstracts with Programs, v. 21, no. 5, p. 151.

Taubeneck WH. 1970. "Dikes of Columbia River Basalt in northeastern Oregon, western Idaho, and southeastern Washington.” In EH Gilmour and D Stradling, eds., Proceedings of the second Columbia River Basalt symposium, Cheney, Washington, Eastern Washington State College Press, p. 73-96.

Taubeneck WH and RA Duncan. 1997. "Preferential occurrence of eruptive axes of dikes of the Columbia River Basalt Group in unmetamorphosed Mesozoic granitic intrusives, with 40Ar/39Ar dates for four dikes and two of the earliest flows of basalt, Northeast Oregon and Western Idaho.” Geological Society of America Abstracts with Programs, v. 29, no. 2, p. 48.

Thordarson T and S Self. 1998. “The Roza Member, Columbia River Basalt Group: A gigantic pahoehoe lava flow field formed by endogenous processes?” Journal of Geophysical Research, v. 103, p. 27,41127,445 .

Tolan TL, SP Reidel, MH Beeson, JL Anderson, KR Fecht, and DA Swanson. 1989. "Revisions to the estimates of the areal extent and volume of the Columbia River Basalt Group.” In SP Reidel and PR Hooper, eds., Volcanism and tectonism in the Columbia River flood-basalt province. Geological Society of America Special Paper 239, p. 1-20.

Tomkeieff SI. 1940. “The Basalt Lavas of the Giant's Causeway District of Northern Ireland.” Bulletin of Volcanology, v. 6, p. 90-143.

Wadge G. 1981. “The variation of magma discharge during basaltic eruptions.” Journal of Volcanology and Geothermal Research, v. 11, p. 139-168.

Walker GW and NS MacLeod. 1991. Geologic Map of Oregon. U.S. Geological Survey, 2 Plates, scale $1: 500,000$.

Waters AC. 1961. "Stratigraphic and lithologic variations in the Columbia River Basalt." American Journal of Science, v. 259, p. 583-611.

Waters AC. 1960. "Determining Direction of Flow in Basalts." American Journal of Science, v. 258-A, p. 350-366. 
Wentworth CK and GA Macdonald. 1953. Structure and forms of basaltic rocks in Hawaii. U.S. Geological Survey Bulletin 994, 98 p. 


\section{Appendix}

Distribution Maps of Columbia River Basalt Group Flows 


\section{Appendix}

\section{Distribution Maps of Columbia River Basalt Group Flows}

\section{Identification of Columbia River Basalt}

Lava flows of the Columbia River Basalt Group (Figure A.1) are identified using a combination of lithology, paleomagnetic properties, and chemical composition. Experience is the best way of making correct identifications but the chemical composition provides the least ambiguous way of properly identifying a lava flow. Table A.1 shows the chemical composition of the larger lava flows of the Columbia River basalt Group. Although this selection does not include every flow known, it provides compositions of the ones that will be of most importance for characterization because of their great lateral extent. 

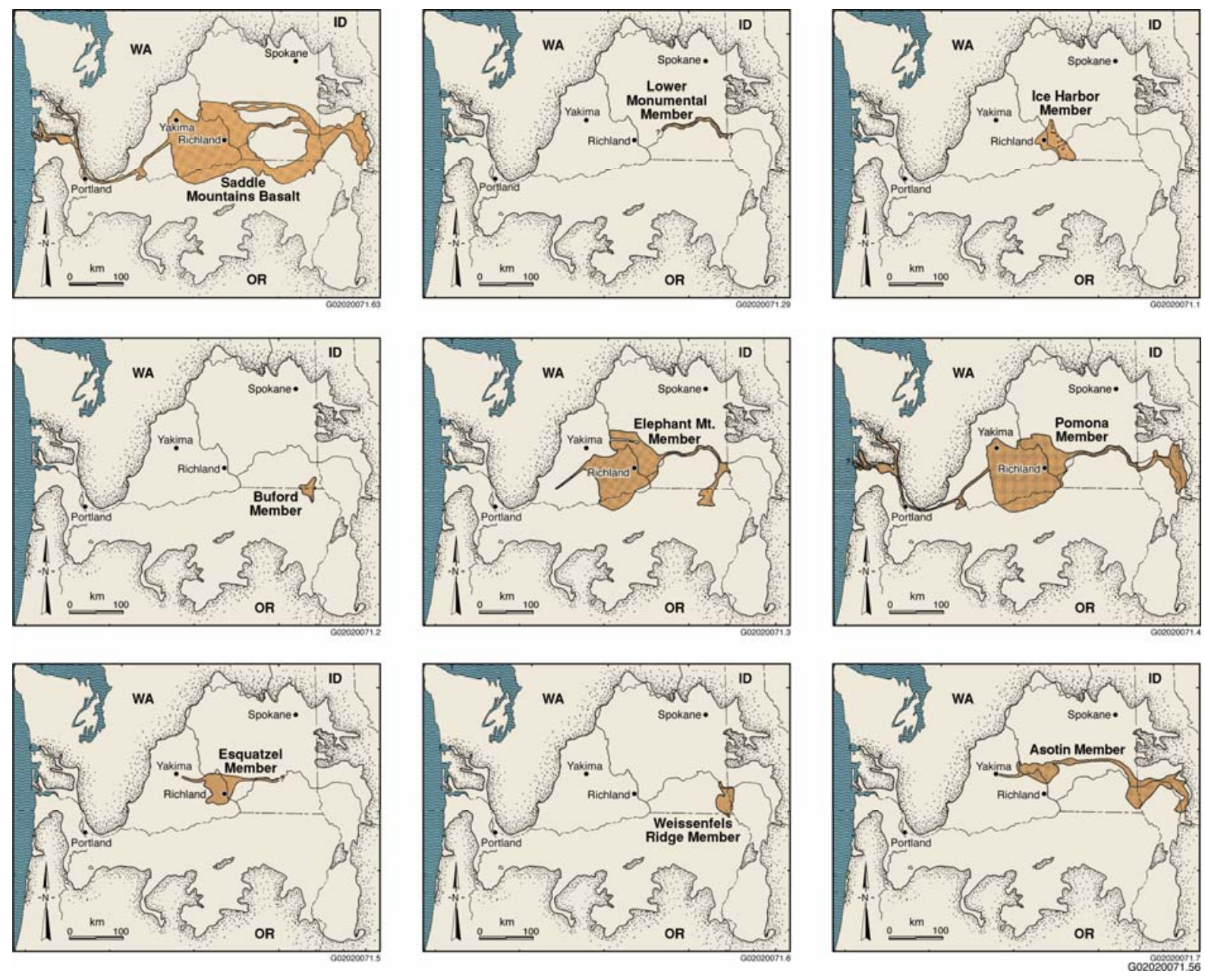

Figure A.1. Distribution Maps of Columbia River Basalt Group Flows (modified from Tolan et al. 1989 and Reidel et al. [1989a]) 

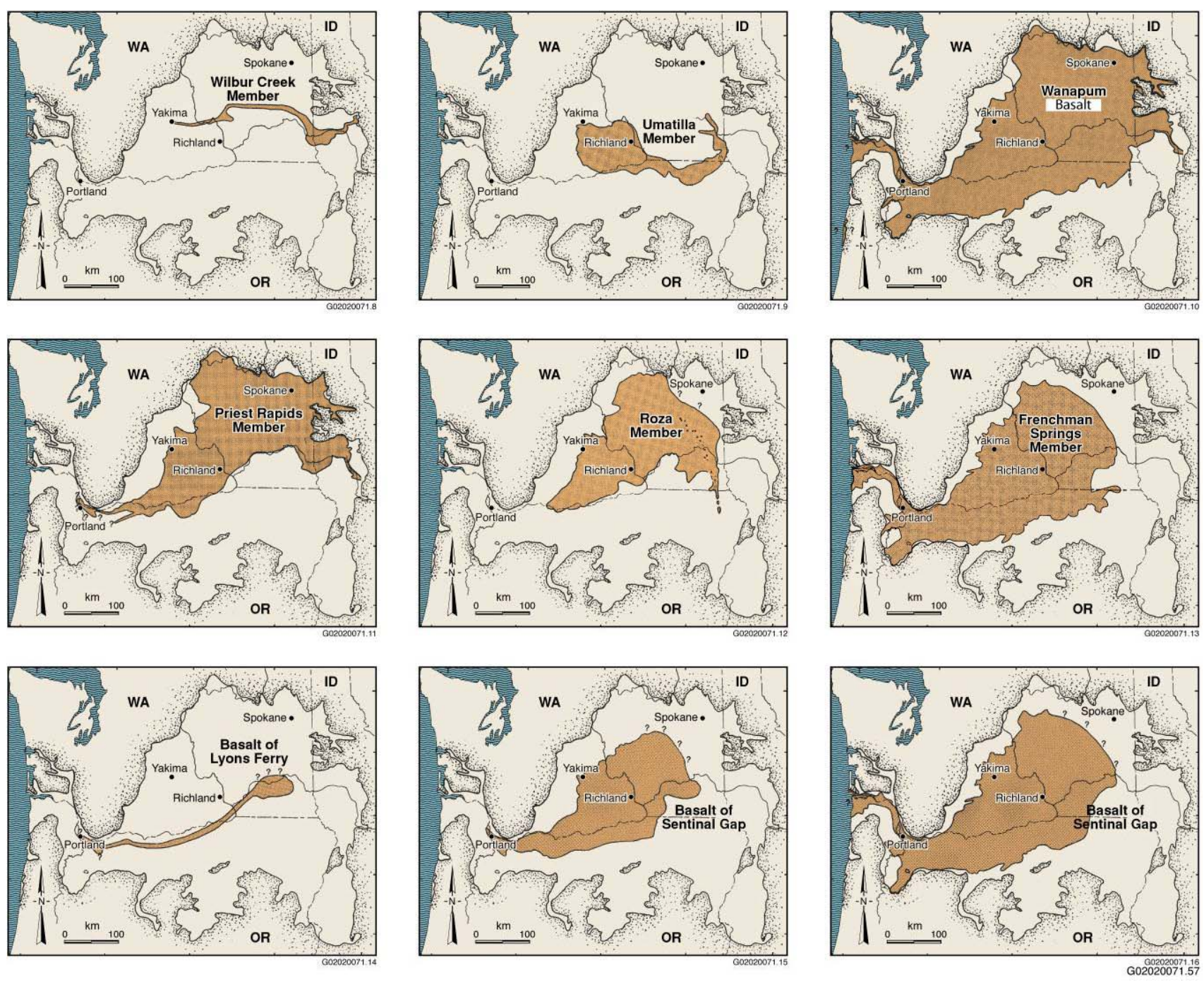

Figure A.1. (contd) 

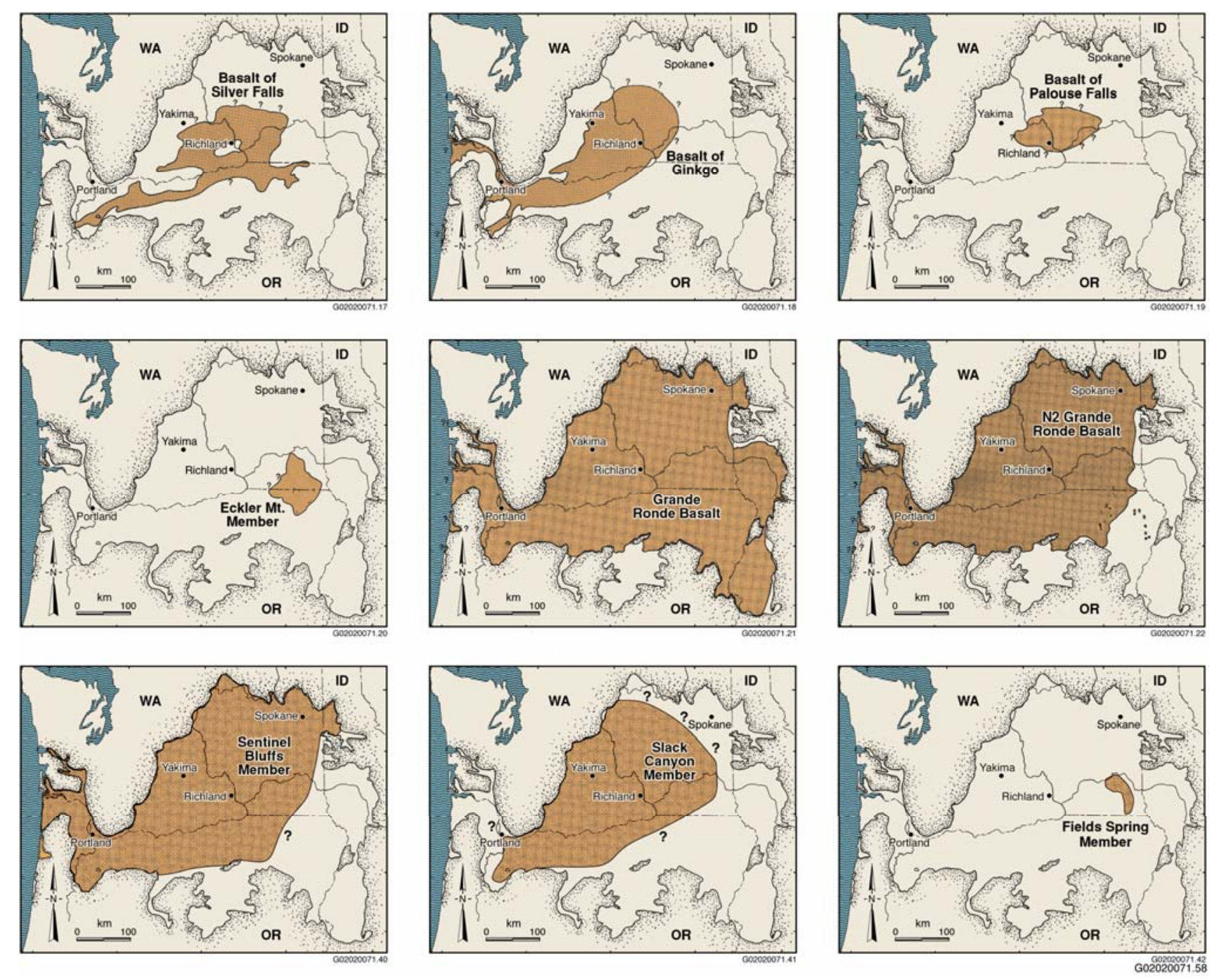

Figure A.1. (contd) 

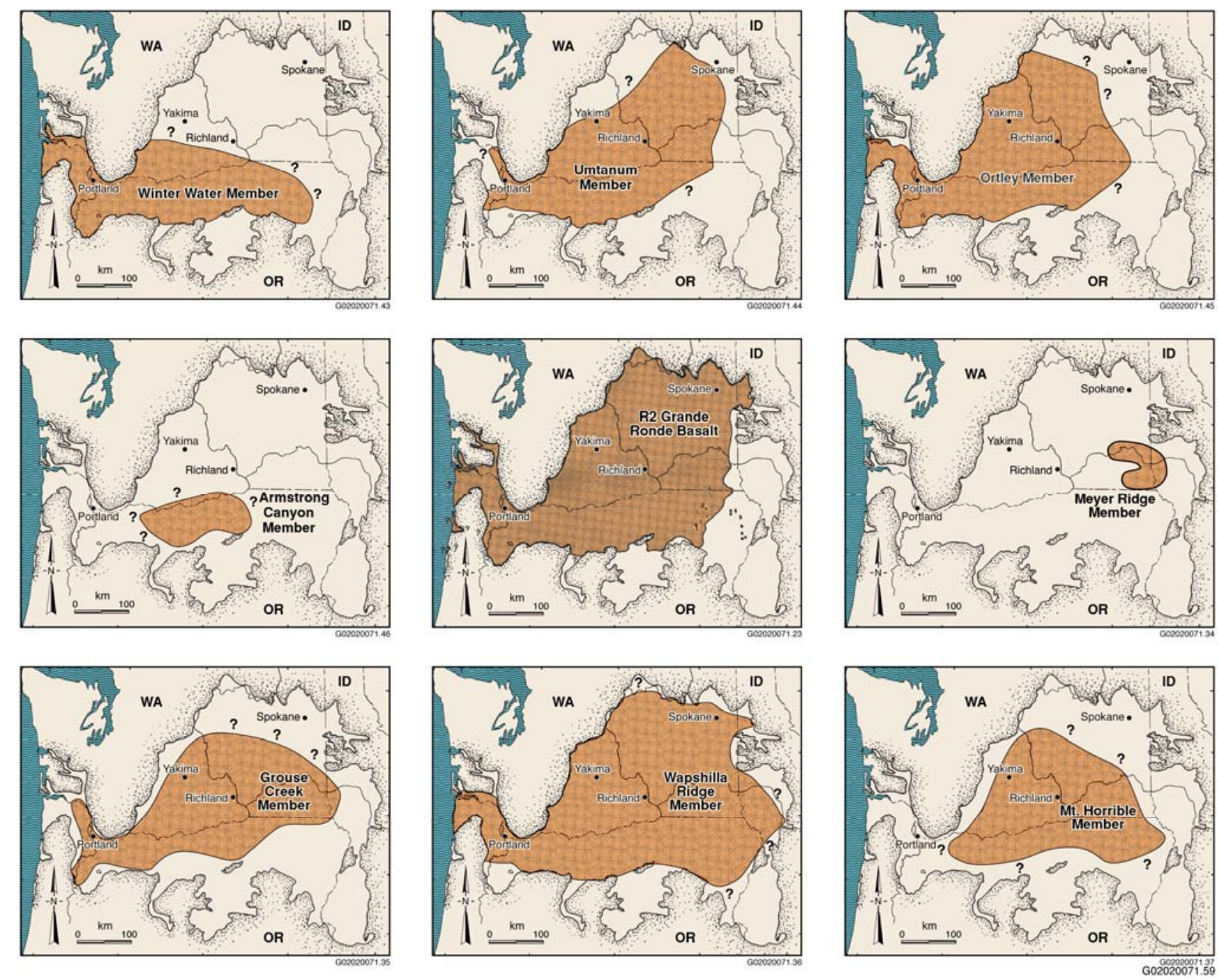

Figure A.1. (contd) 

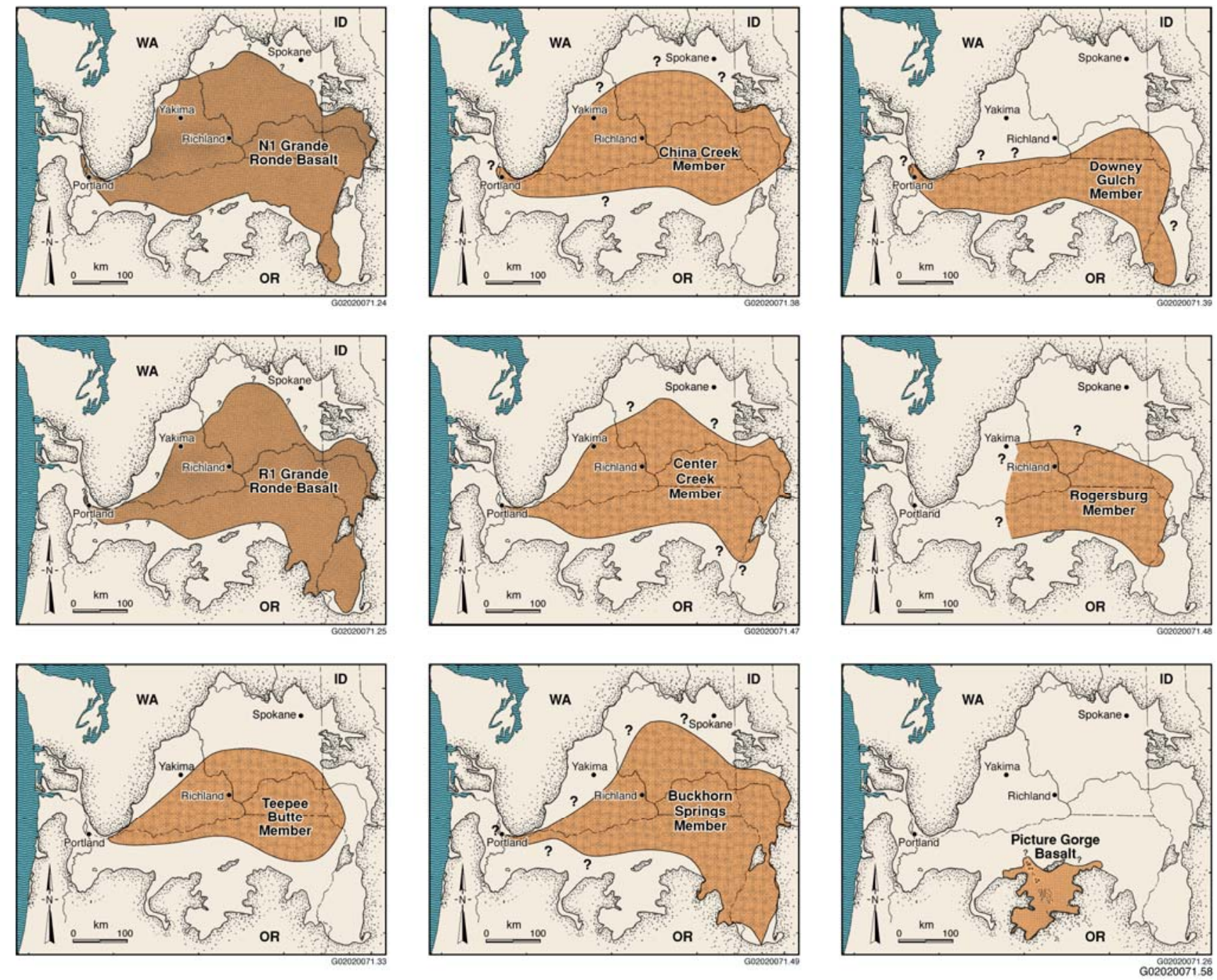

Figure A.1. (contd) 

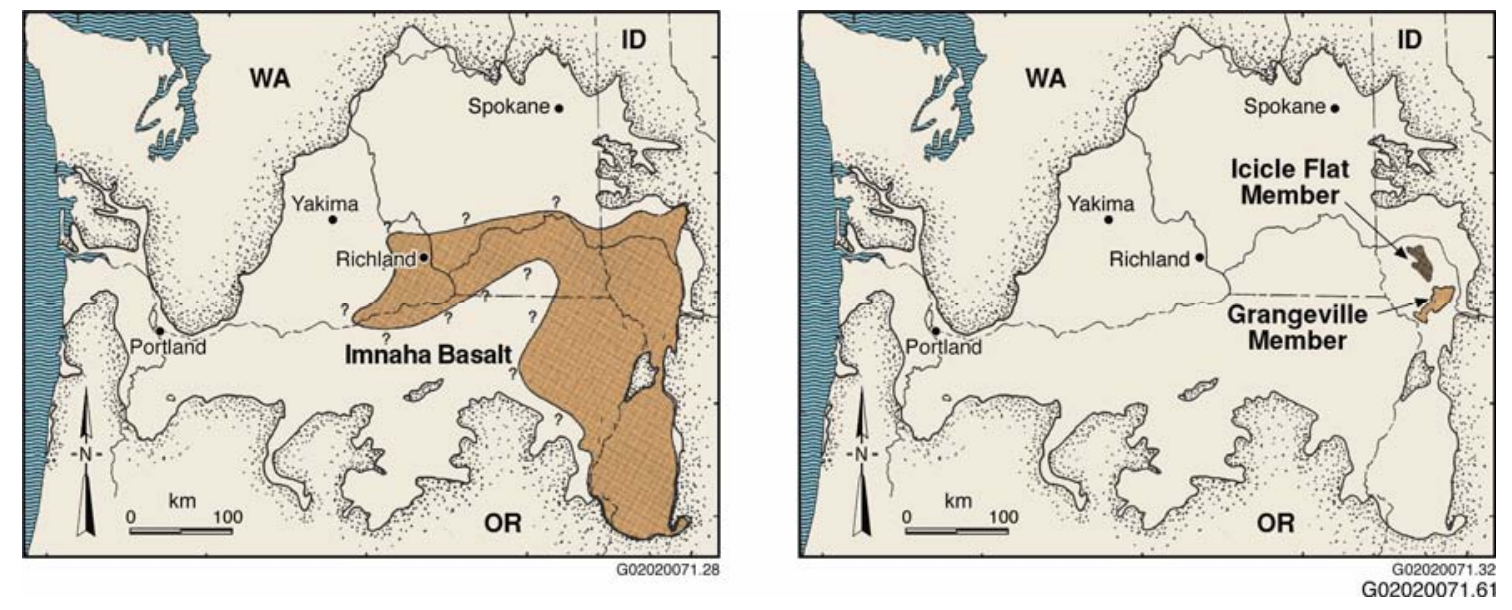

Figure A.1. (contd) 
Table A.1. Representative Chemistries of Columbia River Basalt Flows

Unit Ident.

Saddle Mountains Basalt

Lower Monumental

Lower Monumental

Ice Harbor, basalt of Goose Island

Ice Harbor, basalt of Goose Islan

Ice Harbor, basalt of Martindale

Ice Harbor, basalt of Martindale

Ice Harbor, basalt of Basin City

Ice Harbor, basalt of Basin City

Buford

Buford

Buford

Elephant Mtn.

Elephant Mtn.

Elephant Mtn.

Pomona

\section{Pomona}

Weis. R., basalt of Slip.Cr.

Weis. R., basalt of Slip.Cr.

Weis. R., basalt or Slip.Cr.

Weis. R., basalt of Ten. Cr.

Weis. R., basalt of Ten. Cr.

Weis. R., basalt of Lew. Or.

Weis. R., basalt of Clov.

Asotin

Asotin

Asotin

Wilbur Creek

Wilbur Creek

Wilbur Creek

Esquatzel

Esquatzel

Umatilla, basalt of Sillusi.

Umatilla, basalt of Sillusi.

Umatilla, basalt of Sillusi.

Umatilla, basalt of Sillusi.

Umatilla, basalt of Sillusi.
MAJOR OXIDES (weight per cent)

TRACE ELEMENTS (ppm)

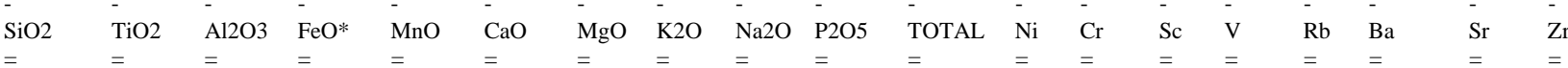

$\begin{array}{lllllllllllllllllll}51.26 & 2.682 & 13.94 & 12.84 & 0.215 & 9.10 & 5.43 & 1.05 & 2.89 & 0.601 & 100.01 & 29 & 76 & 37 & 347 & 25 & 527 & 315 & 190 \\ 51.09 & 2.742 & 13.79 & 13.24 & 0.214 & 9.11 & 5.27 & 1.10 & 2.83 & 0.614 & 100.00 & 25 & 72 & 39 & 352 & 32 & 528 & 323 & 190\end{array}$

$\begin{array}{lllllllllllllllllll}51.09 & 2.742 & 13.79 & 13.24 & 0.214 & 9.11 & 5.27 & 1.10 & 2.83 & 0.614 & 100.00 & 25 & 72 & 39 & 352 & 32 & 528 & 323 & 190 \\ 51.48 & 2.943 & 14.03 & 13.17 & 0.213 & 8.80 & 4.40 & 1.50 & 2.79 & 0.669 & 100.01 & 17 & 25 & 28 & 320 & 33 & 525 & 355 & 178\end{array}$

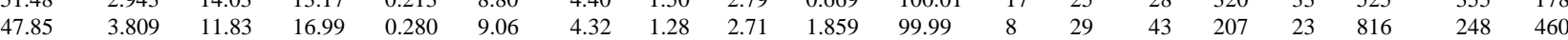

\begin{tabular}{lllllllllllllllllll}
47.98 & 3.703 & 11.54 & 17.69 & 0.288 & 8.76 & 4.18 & 1.34 & 2.70 & 1.824 & 99.99 & 13 & 32 & 41 & 210 & 25 & 870 & 237 & 483 \\
\hline & 3.376 & 13.35 & 14.28 & 0.211 & 10.4 & 6.97 & 0.51 & 2.62 & 0.76 & 99.99 & 33 & 181 & 44 & 360 & 5 & 496 & 253 & 246
\end{tabular}

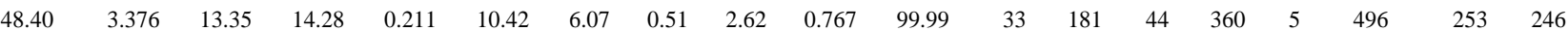

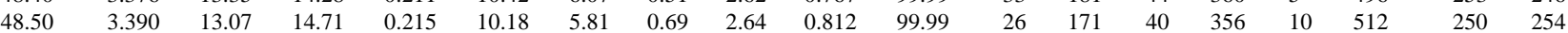

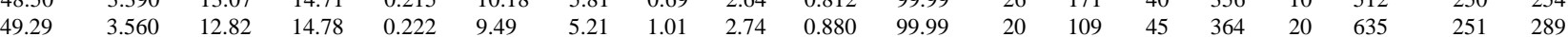

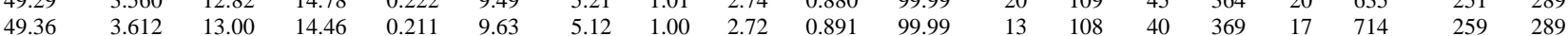

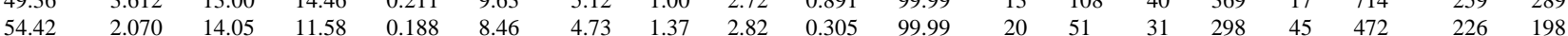

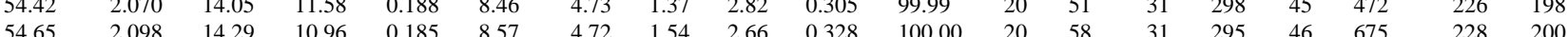

$\begin{array}{lllllllllllllllllll}54.69 & 2.068 & 14.29 & 10.96 & 0.185 & 8.57 & 4.72 & 1.54 & 2.66 & 0.328 & 100.00 & 20 & 58 & 31 & 295 & 46 & 675 & 228 & 200 \\ 52.14 & 3.484 & 14.02 & 11.58 & 0.166 & 8.16 & 4.83 & 1.47 & 2.71 & 0.312 & 100.01 & 18 & 45 & 30 & 295 & 44 & 386 & 210 & 193\end{array}$

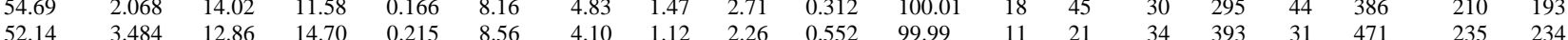

$\begin{array}{lllllllllllllllllll}52.14 & 3.484 & 12.86 & 14.70 & 0.215 & 8.56 & 4.10 & 1.12 & 2.26 & 0.552 & 99.99 & 11 & 21 & 34 & 393 & 31 & 471 & 235 & 234 \\ 51.51 & 3.381 & 13.18 & 14.79 & 0.219 & 8.53 & 4.13 & 1.28 & 2.43 & 0.530 & 99.98 & 10 & 34 & 33 & 398 & 32 & 452 & 234 & 238\end{array}$

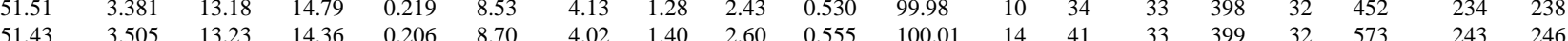

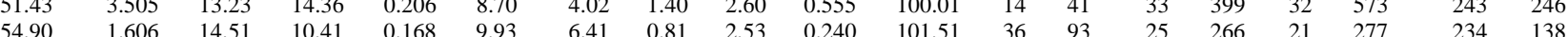

$\begin{array}{llllllllllllllllllll}54.90 & 1.606 & 14.51 & 10.41 & 0.168 & 9.93 & 6.41 & 0.81 & 2.53 & 0.240 & 101.51 & 36 & 93 & 25 & 266 & 21 & 277 & 234 & 138 \\ 53.20 & 1.635 & 14.51 & 10.61 & 0.175 & 10.43 & 6.90 & 0.73 & 2.48 & 0.229 & 100.90 & 40 & 99 & 27 & 278 & 16 & 245 & 228 & 135 \\ \end{array}$

$\begin{array}{llllllllllllllllllll}53.20 & 1.635 & 14.51 & 1.61 & 0.175 & 10.43 & 6.90 & 0.73 & 2.48 & 0.229 & 100.90 & 40 & 99 & 27 & 278 & 16 & 245 & 228 & 135 \\ 54.39 & 1.694 & 14.19 & 10.90 & 0.192 & 8.68 & 4.70 & 1.15 & 3.01 & 0.287 & 99.19 & 15 & 50 & 36 & 301 & 33 & 500 & 308 & 157\end{array}$

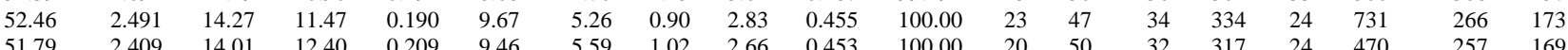

$\begin{array}{llllllllllllllllllll}51.79 & 2.409 & 14.01 & 12.40 & 0.209 & 9.46 & 5.59 & 1.02 & 2.66 & 0.453 & 100.00 & 20 & 50 & 32 & 317 & 24 & 470 & 257 & 169 \\ 51.79 & 2.444 & 14.22 & 12.07 & 0.219 & 9.78 & 5.30 & 1.01 & 2.71 & 0.448 & 99.99 & 24 & 48 & 34 & 313 & 25 & 425 & 257 & 168\end{array}$

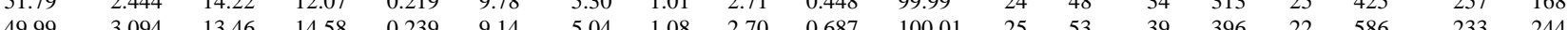

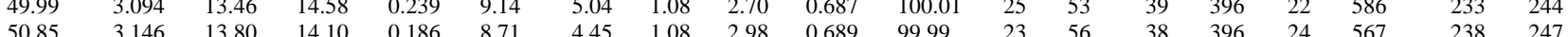

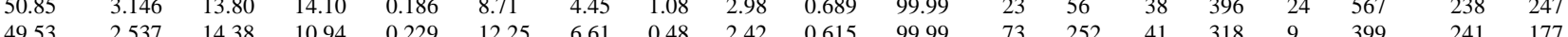

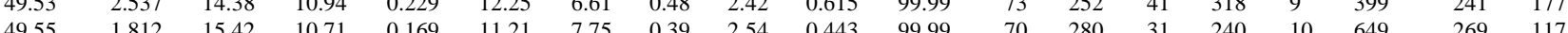

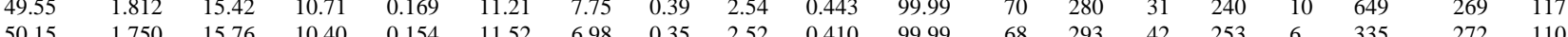

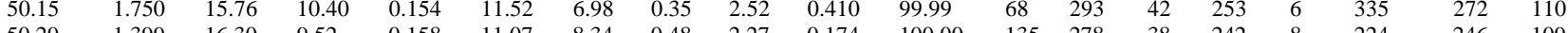

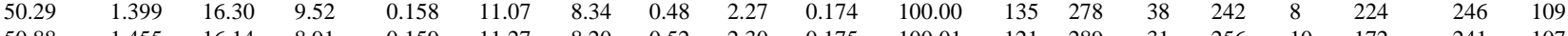

$\begin{array}{lllllllllllllllllll}50.88 & 1.455 & 16.14 & 8.91 & 0.159 & 11.27 & 8.20 & 0.52 & 2.30 & 0.175 & 100.01 & 121 & 289 & 31 & 256 & 10 & 172 & 241 & 107\end{array}$

$\begin{array}{lllllllllllllllllll}51.30 & 1.434 & 16.22 & 8.82 & 0.154 & 11.13 & 7.89 & 0.57 & 2.29 & 0.195 & 100.00 & 139 & 272 & 32 & 238 & 12 & 236 & 262 & 114\end{array}$

$\begin{array}{lllllllllllllllllll}55.20 & 1.863 & 14.67 & 10.46 & 0.157 & 8.29 & 4.28 & 1.74 & 2.79 & 0.538 & 100.00 & 32 & 42 & 33 & 267 & 40 & 833 & 277 & 224\end{array}$

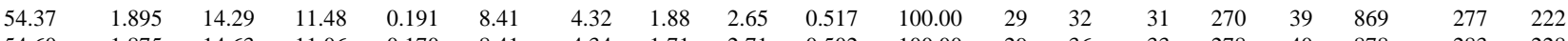

$\begin{array}{lllllllllllllllllll}54.60 & 1.875 & 14.63 & 11.06 & 0.170 & 8.41 & 4.34 & 1.71 & 2.71 & 0.502 & 100.00 & 29 & 36 & 33 & 278 & 40 & 878 & 283 & 228\end{array}$

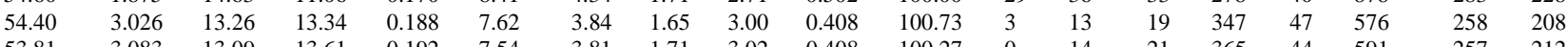

$\begin{array}{lllllllllllllllllll}53.81 & 3.083 & 13.09 & 13.61 & 0.192 & 7.54 & 3.81 & 1.71 & 3.02 & 0.408 & 100.27 & 0 & 14 & 21 & 365 & 44 & 591 & 257 & 212\end{array}$

$\begin{array}{lllllllllllllllllll}56.19 & 2.975 & 14.33 & 10.68 & 0.167 & 6.49 & 2.17 & 2.61 & 3.50 & 0.912 & 100.02 & 14 & 23 & 30 & 217 & 46 & 3195 & 306 & 423 \\ 57.02 & 2.730 & 14.34 & 10.61 & 0.156 & 5.70 & 1.51 & 2.98 & 3.86 & 1.100 & 100.01 & 0 & 0 & 31 & 146 & 50 & 3758 & 290 & 491\end{array}$

$\begin{array}{lllllllllllllllllll}54.72 & 2.670 & 13.63 & 12.12 & 0.195 & 6.51 & 2.73 & 2.89 & 3.56 & 0.970 & 100.00 & 0 & 8 & 30 & 147 & 50 & 3401 & 282 & 449\end{array}$

$\begin{array}{lllllllllllllllllll}55.45 & 2.700 & 13.77 & 11.98 & 0.172 & 6.27 & 2.33 & 2.65 & 3.69 & 0.980 & 99.99 & 0 & 10 & 31 & 153 & 39 & 3475 & 283 & 452 \\ 55.35 & 2.589 & 13.82 & 11.91 & 0.162 & 6.27 & 2.29 & 2.81 & 3.78 & 1.030 & 100.01 & 0 & 14 & 31 & 139 & 36 & 3641 & 289 & 464\end{array}$ 
Table A.1. (contd)

Unit Ident.

Umatilla, basalt of Umatilla Umatilla, basalt of Umatilla Umatilla, basalt of Umatilla Umatilla, basalt of Umatilla Umatilla, basalt of Umatilla

\section{Wanapum Basalt}

Priest Rapids, basalt of Lolo Priest Rapids, basalt of Lolo Priest Rapids, basalt of Lolo

Priest Rapids, basalt of Rosali

Priest Rapids, basalt of Rosali

Priest Rapids, basalt of Rosalia

Schumaker Creek

Schuma

Fr.Spr., basalt of Lyns.Fy.

Fr.Spr., basa

Fr.Spr., basalt or Lyns.Fy.

Fr.Spr., basalt of Sentinel Gap

Fr.Spr., basalt or Sentinel Gap

Fr.Spr., basalt or Sentinel Gap

Fr.Spr., basalt of Sand Hollow

Fr.Spr., basalt of Sand Hollow

Fr.Spr., basalt of Sand Hollow

Fr.Spr., basalt of Silver Falls

Fr.Spr., basalt of Silver Falls

Fr.Spr., basalt of Silver Falls

Fr.Spr., basalt of Ginkgo

Fr.Spr., basalt of Ginkgo

Fr.Spr., basalt of Palouse Falls

Fr.Spr., basalt of Palouse Falls

Fr.Spr., basalt of Palouse Falls

Eckler Mtn., basalt of Dodge

Eckler Mtn., basalt of Dodge
MAJOR OXIDES (weight per cent)

$\begin{array}{llllllllll}54.12 & 3.040 & 13.56 & 12.71 & 0.185 & 6.52 & 2.99 & 2.44 & 3.60 & 0.830 \\ 54.29 & 3.070 & 13.65 & 12.31 & 0.182 & 6.59 & 2.97 & 2.45 & 3.64 & 0.830\end{array}$

$\begin{array}{llllllllll}53.55 & 3.160 & 13.53 & 13.12 & 0.300 & 6.84 & 2.87 & 2.60 & 3.24 & 0.790 \\ 53.81 & 3.130 & 13.51 & 12.78 & 0.201 & 6.75 & 3.18 & 2.59 & 3.28 & 0.780\end{array}$

$\begin{array}{llllllllll}53.94 & 3.120 & 13.75 & 12.54 & 0.188 & 6.68 & 2.98 & 2.43 & 3.56 & 0.810\end{array}$

$\begin{array}{llllllllll}50.58 & 2.632 & 13.41 & 13.97 & 0.230 & 9.44 & 5.74 & 0.97 & 2.68 & 0.725 \\ 49.88 & 3.011 & 13.57 & 13.97 & 0.229 & 9.81 & 5.42 & 1.11 & 2.79 & 0.729\end{array}$

$\begin{array}{llllllllll}50.64 & 3.249 & 13.42 & 14.32 & 0.241 & 9.36 & 5.12 & 1.01 & 2.72 & 0.763\end{array}$

$\begin{array}{llllllllll}50.40 & 3.533 & 12.97 & 14.82 & 0.239 & 8.91 & 4.36 & 1.11 & 2.87 & 0.820\end{array}$

$\begin{array}{llllllllll}49.99 & 3.595 & 12.74 & 14.85 & 0.242 & 9.32 & 4.61 & 1.13 & 2.87 & 0.763\end{array}$

$\begin{array}{llllllllll}49.82 & 3.300 & 14.15 & 12.67 & 0.210 & 10.31 & 4.83 & 1.10 & 2.83 & 0.770\end{array}$

$\begin{array}{llllllllll}51.10 & 3.270 & 13.43 & 13.94 & 0.224 & 8.65 & 4.40 & 1.32 & 2.95 & 0.710\end{array}$

$\begin{array}{llllllllll}51.19 & 3.240 & 13.31 & 14.20 & 0.222 & 8.52 & 4.39 & 1.43 & 2.79 & 0.700 \\ 51.07 & 3.260 & 13.35 & 14.13 & 0.228 & 8.56 & 4.43 & 1.34 & 2.94 & 0.700\end{array}$

$\begin{array}{llllllllll}51.01 & 3.280 & 13.42 & 13.97 & 0.240 & 8.84 & 4.20 & 1.49 & 2.83 & 0.720\end{array}$

$\begin{array}{llllllllll}55.04 & 2.517 & 13.45 & 13.23 & 0.248 & 6.42 & 2.62 & 1.89 & 3.64 & 0.948\end{array}$

$\begin{array}{llllllllll}55.32 & 2.496 & 13.38 & 12.37 & 0.229 & 6.80 & 2.89 & 1.90 & 3.67 & 0.950\end{array}$

$\begin{array}{llllllllll}52.24 & 3.13 & 13.22 & 14.22 & 0.201 & 8.07 & 4.05 & 1.34 & 2.92 & 0.61\end{array}$

$\begin{array}{llllllllll}51.90 & 3.062 & 12.99 & 14.38 & 0.220 & 8.20 & 4.24 & 1.49 & 2.92 & 0.611\end{array}$

$\begin{array}{llllllllll}51.85 & 3.17 & 13.24 & 14.15 & 0.215 & 8.73 & 4.14 & 1.07 & 2.89 & 0.547\end{array}$

$\begin{array}{lllllllllllll}51.93 & 3.085 & 13.13 & 14.42 & 0.218 & 8.31 & 4.36 & 1.33 & 3.21 & 0.612 & 100.61 & 0\end{array}$

$\begin{array}{lllllllllll}51.65 & 3.068 & 13.03 & 14.80 & 0.231 & 8.17 & 4.42 & 1.30 & 3.12 & 0.612 & 100 \\ 5 & 3.053 & 14.29 & 12.39 & 0.184 & 9.07 & 3.83 & 1.16 & 2.74 & 0.627 & 109 .\end{array}$

\begin{tabular}{llllllllllllll}
52.65 & 3.053 & 14.29 & 14.39 & 0.231 & 8.17 & 4.42 & 1.30 & 3.12 & 0.614 & 100.40 & 3 & 31 \\
5 & 3.165 & 14.76 & 11.64 & 0.177 & 9.07 & 3.83 & 1.16 & 2.74 & 0.627 & 99.99 & 32 & 76 \\
\hline
\end{tabular}

\begin{tabular}{llllllllllllll}
52.62 & 3.053 & 14.29 & 12.39 & 0.184 & 9.07 & 3.83 & 1.16 & 2.74 & 0.627 & 99.99 & 32 & 76 \\
\hline 50.98 & 3.026 & 13.99 & 11.64 & 0.177 & 9.33 & 3.73 & 1.11 & 2.83 & 0.632 & 99.99 & 19 & 74
\end{tabular}

$\begin{array}{llllllllll}50.98 & 3.026 & 13.99 & 11.64 & 0.177 & 9.33 & 3.73 & 1.11 & 2.83 & 0.632\end{array}$

$\begin{array}{lllllllllll}51.25 & 3.106 & 13.42 & 14.66 & 0.226 & 8.47 & 4.08 & 1.13 & 3.05 & 0.616 & 1\end{array}$

$\begin{array}{llllllllll}51.46 & 3.115 & 13.22 & 14.62 & 0.223 & 8.47 & 4.08 & 1.13 & 3.05 & 0.616 \\ & 5.110 & 13.30 & 14.81 & 0.222 & 8.34 & 4.23 & 1.32 & 3.06 & 0.632\end{array}$

$\begin{array}{llllllllll}51.50 & 3.110 & 13.30 & 14.81 & 0.222 & 8.34 & 4.27 & 1.37 & 3.00 & 0.618\end{array}$

$\begin{array}{llllllllll}51.62 & 3.133 & 13.27 & 14.62 & 0.231 & 8.33 & 3.96 & 1.27 & 3.02 & 0.699\end{array}$

$\begin{array}{lllllllllll}51.71 & 3.108 & 13.23 & 14.90 & 0.230 & 8.19 & 4.19 & 1.26 & 3.14 & 0.679\end{array}$

$\begin{array}{llllll}51.40 & 3.102 & 13.19 & 14.90 & -0.228 & 8.22\end{array}$

$\begin{array}{lllllllllll}51.29 & 3.125 & 13.17 & 14.36 & 0.236 & 8.56 & 4.25 & 0.93 & 3.10 & 0.537\end{array}$

$\begin{array}{llllllllll}51.74 & 3.275 & 13.45 & 14.19 & 0.221 & 8.26 & 4.19 & 1.14 & 3.28 & 0.558\end{array}$

\begin{tabular}{lllllllllll}
52.16 & 3.195 & 13.51 & 14.21 & 0.244 & 8.11 & 4.01 & 1.14 & 3.27 & 0.552 \\
\hline
\end{tabular}

$\begin{array}{lllllllllll}52.31 & 1.457 & 15.69 & 11.14 & 0.129 & 10.17 & 5.33 & 0.51 & 2.92 & 0.334 \\ 51.62 & 1.448 & 15.03 & 10.93 & 0.185 & 10.49 & 6.26 & 0.52 & 3.17 & 0.344\end{array}$

51.77
TRACE ELEMENTS (ppm)

$\begin{array}{lllllllll}\text { TOTAL } & \mathrm{Ni} & \mathrm{Cr} & \mathrm{Sc} & \mathrm{V} & \mathrm{Rb} & \mathrm{Ba} & \mathrm{Sr} & \mathrm{Zr} \\ = & = & = & = & = & = & = & = & = \\ 100.00 & 0 & 12 & 35 & 224 & 44 & 2833 & 273 & 406 \\ 99.98 & 0 & 12 & 31 & 233 & 45 & 2839 & 273 & 405 \\ 100.00 & 0 & 14 & 33 & 2 & 46 & 2731 & 286 & 395 \\ 100.01 & 5 & 19 & 29 & 252 & 48 & 2743 & 280 & 408 \\ 100.00 & 0 & 13 & 30 & 245 & 43 & 2849 & 279 & 412 \\ & & & & & & & & \\ 100.38 & 33 & 99 & 41 & 320 & 25 & 510 & 290 & 181 \\ 100.52 & 36 & 102 & 39 & 348 & 29 & 506 & 272 & 180 \\ 100.84 & 29 & 93 & 39 & 363 & 27 & 505 & 283 & 184 \\ 100.03 & 7 & 25 & 44 & 427 & 21 & 606 & 301 & 223 \\ 100.11 & 6 & 25 & 42 & 406 & 25 & 567 & 291 & 207 \\ 99.99 & 27 & 97 & 44 & 364 & 23 & 483 & 310 & 179 \\ 99.99 & 10 & 36 & 38 & 406 & 33 & 545 & 307 & 191 \\ 99.99 & 7 & 35 & 43 & 416 & 34 & 576 & 308 & 191 \\ 100.01 & 6 & 33 & 47 & 412 & 32 & 553 & 305 & 191 \\ 100.00 & 8 & 31 & 42 & 424 & 34 & 544 & 309 & 191 \\ 100.00 & 0 & 5 & 39 & 163 & 49 & 1040 & 331 & 244 \\ 100.01 & 0 & 6 & 39 & 160 & 44 & 1021 & 327 & 245 \\ 100.01 & 0 & 6 & 38 & 154 & 50 & 1015 & 328 & 248 \\ 100.00 & 0 & 26 & 47 & 462 & 41 & 545 & 310 & 192 \\ 100.01 & 3 & 25 & 39 & 446 & 33 & 579 & 315 & 193 \\ 100.00 & 3 & 32 & 45 & 457 & 20 & 549 & 324 & 182 \\ 100.33 & 1 & 27 & 41 & 429 & 38 & 554 & 312 & 193 \\ 100.61 & 0 & 28 & 40 & 444 & 34 & 579 & 304 & 189 \\ 100.40 & 3 & 31 & 38 & 431 & 31 & 582 & 305 & 192 \\ 99.99 & 32 & 76 & 40 & 425 & 27 & 541 & 314 & 181 \\ 99.99 & 19 & 74 & 41 & 452 & 30 & 521 & 339 & 185 \\ 100.00 & 23 & 72 & 37 & 423 & 22 & 566 & 317 & 174 \\ 100.01 & 1 & 25 & 42 & 416 & 31 & 543 & 325 & 179 \\ 100.24 & 2 & 22 & 38 & 416 & 37 & 562 & 324 & 182 \\ 100.54 & 1 & 24 & 41 & 406 & 36 & 542 & 322 & 180 \\ 100.15 & 1 & 24 & 41 & 383 & 36 & 546 & 324 & 183 \\ 100.64 & 0 & 25 & 39 & 390 & 35 & 564 & 323 & 183 \\ 100.32 & 1 & 25 & 41 & 386 & 30 & 570 & 320 & 179 \\ 99.56 & 12 & 43 & 45 & 386 & 22 & 494 & 301 & 163 \\ 100.30 & 13 & 36 & 44 & 415 & 28 & 549 & 304 & 167 \\ 100.40 & 11 & 38 & 42 & 391 & 29 & 535 & 303 & 173 \\ 99.99 & 36 & 171 & 46 & 316 & 9 & 342 & 387 & 125 \\ 100.00 & 38 & 150 & 49 & 344 & 8 & 309 & 395 & 126 \\ 100.01 & 40 & 155 & 47 & 340 & 12 & 330 & 399 & 125\end{array}$


Table A.1. (contd)

Unit Ident.

Eckler Mtn., basalt of Dodge

Eckler Mtn., basalt of Rob. Mtn.

\section{Grande Ronde Basalt}

Sentinel Bluffs Member - Museum

Sentinel Bluffs Member - Museum

Sentinel Bluffs Member - Spokane Falls

Sentinel Bluffs Member - Spokane Falls

Sentinel Bluffs Member - Stember Creek

Sentinel Bluffs Member - Stember Creek

Sentinel Bluffs Member - Airway Heights

Sentinel Bluffs Member - Airway Heights

Sentinel Blufts Member - California Creek

Sentinel Bluffs Member - California Cree

Sentinel Bluffs Menter - McCoy Canyon

Sentinel Bluffs Member - McCoy Canyon

Member of Umtanum

Member of Fields Spring
Member of Fields Spring

Member of Fields Spring

Member of Fields Spring

Member of Ortley

Member of Ortley

Member of Ortley

Member of Meyer Ridge

Member of Meyer Ridge

Member of Wapshilla Ridge

Member of Wapshilla Ridge

Member of Wapshilla Ridge

Member of Wapshilla Ridge

R2 MSU undiff.

R2 MSU undiff.

R2 MSU undiff.

R2 MSU undiff.

R2 MSU undiff.

Member of China Creek

Member of China Creek

Member of China Creek

Member of Downey Gulch

Member of Downey Gulch

Menth

Member of Downey Gulch
MAJOR OXIDES (weight per cent)

TRACE ELEMENTS (ppm)

\begin{tabular}{|c|c|c|c|c|c|c|c|c|c|c|c|c|c|c|c|c|c|}
\hline $\begin{array}{l}\mathrm{TiO} 2 \\
=\end{array}$ & $\begin{array}{l}\text { Al2O3 } \\
=\end{array}$ & $\begin{array}{l}\mathrm{FeO} * \\
=\end{array}$ & $\begin{array}{l}\mathrm{MnO} \\
=\end{array}$ & $\begin{array}{l}\mathrm{CaO} \\
=\end{array}$ & $\begin{array}{l}\mathrm{MgO} \\
=\end{array}$ & $\begin{array}{l}\mathrm{K} 2 \mathrm{O} \\
=\end{array}$ & $\begin{array}{l}\mathrm{Na} 2 \mathrm{O} \\
=\end{array}$ & $\begin{array}{l}\mathrm{P} 2 \mathrm{O} 5 \\
=\end{array}$ & $\begin{array}{l}\text { TOTAL } \\
=\end{array}$ & $\begin{array}{l}\mathrm{Ni} \\
=\end{array}$ & $\begin{array}{l}\mathrm{Cr} \\
=\end{array}$ & $\begin{array}{l}\text { Sc } \\
=\end{array}$ & $\begin{array}{l}\mathrm{V} \\
=\end{array}$ & $\begin{array}{l}\mathrm{Rb} \\
=\end{array}$ & $\begin{array}{l}\text { Ba } \\
=\end{array}$ & $\begin{array}{l}\mathrm{Sr} \\
=\end{array}$ & $\begin{array}{l}\mathrm{Zr} \\
=\end{array}$ \\
\hline 1.507 & 15.37 & 10.26 & 0.190 & 10.53 & 6.23 & 0.56 & 3.20 & 0.361 & 99.99 & 42 & 158 & 46 & 334 & 10 & 335 & 395 & 128 \\
\hline 0.958 & 17.12 & 10.27 & 0.182 & 11.13 & 7.95 & 0.24 & 2.53 & 0.174 & 99.99 & 82 & 145 & 37 & 263 & 4 & 129 & 333 & 72 \\
\hline 14.82 & 1.758 & 11.16 & 0.194 & 9.15 & 4.90 & 0.89 & 2.92 & 0.290 & 100.00 & 13 & 56 & 37 & 319 & 21 & 407 & 318 & 159 \\
\hline 14.58 & 1.723 & 11.28 & 0.202 & 9.01 & 4.94 & 0.90 & 3.07 & 0.289 & 100.00 & 11 & 51 & 39 & 300 & 26 & 471 & 310 & 152 \\
\hline 4.11 & 1.833 & 11.91 & 0.205 & 8.82 & 5.04 & 1.32 & 2.82 & 0.303 & 100.00 & 16 & 54 & 40 & 312 & 37 & 497 & 300 & 157 \\
\hline 14.05 & 1.843 & 11.73 & 0.203 & 8.76 & 4.91 & 1.27 & 2.97 & 0.296 & 100.00 & 15 & 49 & 39 & 312 & 29 & 506 & 302 & 153 \\
\hline 13.42 & 1.744 & 15.02 & 0.290 & 8.67 & 4.82 & 1.04 & 2.77 & 0.279 & 100.00 & 15 & 60 & 33 & 298 & 26 & 457 & 286 & 144 \\
\hline 14.27 & 1.759 & 11.60 & 0.204 & 9.10 & 5.35 & 1.13 & 2.82 & 0.272 & 100.00 & 17 & 60 & 39 & 314 & 28 & 463 & 305 & 147 \\
\hline 14.08 & 1.910 & 11.71 & 0.213 & 8.74 & 4.92 & 1.24 & 2.86 & 0.369 & 100.00 & 13 & 50 & 39 & 279 & 30 & 533 & 303 & 161 \\
\hline 14.08 & 1.907 & 11.57 & 0.212 & 8.68 & 4.82 & 1.26 & 2.90 & 0.373 & 100.00 & 15 & 49 & 41 & 292 & 30 & 528 & 301 & 161 \\
\hline 13.99 & 1.948 & 11.78 & 0.215 & 8.51 & 4.72 & 1.26 & 2.99 & 0.421 & 100.00 & 10 & 43 & 34 & 264 & 32 & 556 & 306 & 165 \\
\hline 13.95 & 1.966 & 11.45 & 0.217 & 8.46 & 4.60 & 1.30 & 2.91 & 0.427 & 100.00 & 11 & 40 & 35 & 262 & 34 & 555 & 308 & 166 \\
\hline 13.96 & 1.920 & 11.91 & 0.214 & 8.70 & 4.71 & 0.97 & 3.16 & 0.293 & 100.00 & 8 & 34 & 40 & 333 & 29 & 493 & 313 & 154 \\
\hline 13.95 & 1.926 & 12.02 & 0.212 & 8.70 & 4.75 & 0.97 & 3.11 & 0.296 & 100.00 & 7 & 37 & 37 & 323 & 29 & 497 & 313 & 155 \\
\hline 2.191 & 13.45 & 12.64 & 0.210 & 7.17 & 3.43 & 1.62 & 3.38 & 0.384 & 100.27 & 0 & 12 & 3 & 325 & 45 & 608 & 308 & 180 \\
\hline 2.162 & 13.43 & 12.55 & 0.205 & 7.10 & 3.40 & 1.56 & 3.43 & 0.385 & 100.24 & 0 & 17 & 3 & 324 & 45 & 615 & 310 & 179 \\
\hline 2.286 & 13.35 & 12.94 & 0.210 & 7.15 & 3.3 & 1.45 & 3.47 & 0.390 & 100.17 & 2 & 18 & 3 & 315 & 49 & 6 & 308 & 183 \\
\hline 1.169 & 15.22 & 9.76 & 0.176 & 10.28 & 6.25 & 0.54 & 2.92 & 0.262 & 100.01 & 17 & 101 & 4 & 283 & 11 & 40 & 395 & 123 \\
\hline 1.154 & 15.02 & 9.15 & 0.226 & 10.19 & 6.19 & 0.76 & 2.91 & 0.266 & 100.01 & 15 & 94 & 5 & 26 & 16 & 42 & 388 & 122 \\
\hline 1.098 & 15.27 & 9.46 & 0.172 & 10.61 & 6.57 & 0.52 & 2.94 & 0.250 & 99.99 & 21 & 100 & 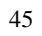 & 25 & 10 & 355 & 391 & 114 \\
\hline 1.175 & 14.83 & 9.62 & 0.183 & 10.16 & 6.15 & 0.80 & 2.95 & 0.273 & 100.00 & 18 & 95 & 47 & 26 & 6 & 466 & 388 & 124 \\
\hline 2.122 & 13.82 & 13.08 & 0.213 & 7.45 & 3.74 & 1.54 & 3.05 & 0.370 & 101.135 & 5 & 27 & 31 & 349 & 45 & 584 & 316 & 173 \\
\hline 2.130 & 14.21 & 13.13 & 0.212 & 7.36 & 3.81 & 1.54 & 2.95 & 0.370 & 102.822 & 3 & 25 & 31 & 341 & 14 & 614 & 311 & 173 \\
\hline 1.915 & 13.75 & 11.80 & 0.190 & 7.07 & 3.40 & 1.74 & 3.35 & 0.335 & 100.46 & 0 & 17 & 33 & 283 & 49 & 655 & 316 & 176 \\
\hline 1.730 & 14.84 & 11.79 & 0.200 & 8.10 & 3.97 & 1.20 & 3.09 & 0.280 & 99.99 & 31 & - & & 259 & 21 & 546 & 318 & 147 \\
\hline 1.730 & 14.83 & 11.70 & 0.200 & 8.12 & 4.02 & 1.20 & 3.06 & 0.280 & 99.99 & 43 & - & 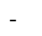 & 289 & 23 & 518 & 318 & 148 \\
\hline 2.460 & 14.68 & 11.73 & 0.107 & 5.61 & 2.14 & 1.79 & 3.74 & 0.441 & 100.00 & 10 & 20 & 41 & 353 & 8 & 72 & 331 & 194 \\
\hline 2.629 & 14.05 & 13.97 & 0.145 & 6.6 & 2.4 & 1.95 & 3.6 & 0.499 & 10 & & 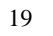 & 3 & 42 & 4 & 7 & 336 & 194 \\
\hline 64 & 14.04 & 13.74 & 0.147 & 6.7 & 2. & 1.96 & 3.6 & 0.499 & 100.00 & & 21 & 37 & 41 & 45 & 70 & 334 & 193 \\
\hline 2.241 & 13.66 & 13.09 & 0.188 & 7.36 & 3. & 1.64 & 3.47 & 0.501 & 100.00 & & 18 & 44 & 37 & 35 & 6 & 317 & 181 \\
\hline 1.891 & 14.14 & 12.20 & 0.1 & 8.3 & 4. & 1.32 & 2.75 & 0.416 & 100.00 & 5 & 41 & 39 & 24 & 11 & 496 & 317 & 163 \\
\hline 2.362 & 13.52 & 13.01 & 0.214 & 7.1 & 3. & 1.78 & 3.01 & 0.400 & 100.00 & & 16 & 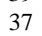 & 36 & 46 & 65 & 321 & 172 \\
\hline 2.294 & 13.62 & 12.80 & 0.186 & 7.27 & 3.6 & 1.63 & 3.71 & 0.450 & 100.00 & 5 & 14 & ? & 379 & 42 & 648 & 312 & 181 \\
\hline 2.202 & 13.70 & 13.18 & 0.179 & 7.55 & 3.77 & 1.57 & 3.22 & 0.420 & 100.00 & 3 & 20 & 46 & 362 & 44 & 59 & 324 & 180 \\
\hline 2.511 & 13.68 & 12.57 & 0.2 & 7.26 & 3.6 & 1.81 & 3.50 & 0.445 & 100.00 & 1 & 15 & 4 & 4 & 43 & 68 & 316 & 193 \\
\hline 2.563 & 13.74 & 12.82 & 0.171 & 6.94 & 4. & 1.68 & 3.4 & 0.436 & 100.00 & 9 & 20 & 37 & 43 & 43 & 63 & 314 & 187 \\
\hline 1.973 & 14.19 & 11.75 & 0.207 & 7.96 & 4.12 & 1.10 & 3.31 & 0.348 & 100.00 & 5 & 20 & 36 & 390 & 20 & 535 & 325 & 160 \\
\hline 1.693 & 14.43 & 11.04 & 0.1 & 7.5 & 4. & 1.23 & 3.16 & 0.247 & 100.00 & 8 & 28 & 39 & 31 & 37 & 44 & 318 & 142 \\
\hline 171 & 14.5 & 10 & 0.179 & 8.4 & 4. & 1. & 2 & 0.272 & 100.00 & 10 & 28 & 39 & 31 & 2 & 44 & 324 & 44 \\
\hline .180 & 13.66 & 11 & 0.1 & 6.5 & 2. & 2. & 3. & & 99 & 5 & & & 32 & 5 & 6 & 315 & 196 \\
\hline 2.050 & 13.98 & 11.79 & 0.170 & 7.60 & 3.85 & 1.65 & 2.84 & 0.290 & 99.98 & 30 & - & - & 309 & 42 & 55 & 318 & 173 \\
\hline 2.060 & 14.10 & 11. & 0.1 & 7.60 & 3.8 & 1.6 & 2.8 & 0.290 & 99. & 3 & - & & 34 & 45 & 60 & 320 & 178 \\
\hline 2.000 & 13.75 & 12.04 & 0.210 & 7.75 & 3.91 & 1.57 & 3.02 & 0.310 & 100.00 & 27 & & & 323 & 40 & 572 & 317 & 172 \\
\hline
\end{tabular}


Table A.1. (contd)

Unit Ident.

R1 MSU undiff.

R1 MSU undiff.

R1 MSU undiff.

R1 MSU undiff.

Teepee Butte Member

Teepee Butte Membe

Teepee Butte Member

R1 MSU undiff.

R1 MSU undiff.

R1 MSU undiff.

R1 MSU undiff.

R1 MSU undiff.

R1 MSU undiff.

R1 MSU undiff.

R1 MSU undiff.

R1 MSU undiff.

Imnaha Basalt

Imnaha undiff.

Imnaha undiff.

Imnaha undiff.

Imnaha undiff.

Imnaha undiff.

Imnaha undiff.

Imnaha undiff.
MAJOR OXIDES (weight per cent)

TRACE ELEMENTS (ppm)

\begin{tabular}{|c|c|c|c|c|c|c|c|c|c|c|c|c|c|c|c|c|c|}
\hline $\begin{array}{l}\mathrm{TiO} 2 \\
=\end{array}$ & $\begin{array}{l}\mathrm{Al} 2 \mathrm{O} 3 \\
=\end{array}$ & $\begin{array}{l}\mathrm{FeO}^{*} \\
=\end{array}$ & $\begin{array}{l}\mathrm{MnO} \\
=\end{array}$ & $\begin{array}{l}\mathrm{CaO} \\
=\end{array}$ & $\begin{array}{l}\mathrm{MgO} \\
=\end{array}$ & $\begin{array}{l}\mathrm{K} 2 \mathrm{O} \\
=\end{array}$ & $\begin{array}{l}\mathrm{Na} 2 \mathrm{O} \\
=\end{array}$ & $\begin{array}{l}\mathrm{P} 2 \mathrm{O} 5 \\
=\end{array}$ & $\begin{array}{l}\text { TOTAL } \\
=\end{array}$ & $\begin{array}{l}\mathrm{Ni} \\
=\end{array}$ & $\begin{array}{l}\mathrm{Cr} \\
=\end{array}$ & $\begin{array}{l}\text { Sc } \\
=\end{array}$ & $\begin{array}{l}\mathrm{V} \\
=\end{array}$ & $\begin{array}{l}\mathrm{Rb} \\
=\end{array}$ & $\begin{array}{l}\text { Ba } \\
=\end{array}$ & $\begin{array}{l}\mathrm{Sr} \\
=\end{array}$ & $\begin{array}{l}\mathrm{Zr} \\
=\end{array}$ \\
\hline 2.180 & 13.88 & 12.16 & 0.240 & 7.35 & 3.96 & 1.48 & 3.49 & 0.440 & 99.99 & 21 & 19 & 37 & 331 & 31 & 606 & 347 & 186 \\
\hline 2.180 & 14.00 & 12.54 & 0.220 & 8.37 & 4.25 & 1.01 & 3.38 & 0.420 & 100.00 & 30 & 18 & 37 & 418 & 15 & 500 & 319 & 183 \\
\hline 2.350 & 13.97 & 11.85 & 0.200 & 8.64 & 4.65 & 1.29 & 2.95 & 0.360 & 100.00 & 32 & 61 & 34 & 318 & 28 & 451 & 340 & 176 \\
\hline 2.350 & 14.10 & 11.73 & 0.190 & 8.61 & 4.56 & 1.27 & 2.83 & 0.400 & 100.01 & 37 & 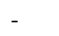 & - & 328 & 40 & 491 & 351 & 180 \\
\hline 2.290 & 14.03 & 12.33 & 0.210 & 9.12 & 5.18 & 1.06 & 2.89 & 0.340 & 100.01 & 79 & - & & 325 & 27 & 381 & 341 & 175 \\
\hline 2.400 & 14.44 & 12.18 & 0.210 & 8.97 & 5.05 & 1.11 & 2.89 & 0.350 & 100.02 & 86 & - & & 338 & 13 & 395 & 342 & 177 \\
\hline 2.290 & 14.15 & 12.17 & 0.220 & 9.27 & 5.24 & 0.99 & 2.96 & 0.330 & 99.99 & 51 & - & & 330 & 22 & 379 & 343 & 174 \\
\hline 1.860 & 14.49 & 11.41 & 0.210 & 9.22 & 5.10 & 0.97 & 2.95 & 0.300 & 100.00 & 39 & 82 & 35 & 339 & & 344 & 344 & 153 \\
\hline 2.230 & 13.71 & 12.48 & 0.250 & 7.83 & 4.05 & 1.40 & 3.28 & 0.380 & 99.99 & 28 & . & . & 378 & 33 & 500 & 313 & 183 \\
\hline 2.230 & 13.72 & 12.86 & 0.230 & 7.78 & 4.19 & 1.30 & 3.28 & 0.380 & 99.99 & 38 & - & 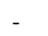 & 372 & 21 & 52 & 316 & 181 \\
\hline 2.280 & 13.90 & 12.15 & 0.190 & 7.90 & 4.21 & 1.42 & 3.26 & 0.380 & 100.00 & 51 & 34 & 33 & 337 & 6 & 5 & 330 & 184 \\
\hline 2.290 & 13.92 & 12.02 & 0.190 & 8.01 & 4.24 & 1.37 & 3.14 & 0.380 & 100.00 & 41 & - & . & 298 & 23 & 527 & 343 & 186 \\
\hline 2.270 & 14.12 & 11.77 & 0.230 & 8.09 & 3.97 & 1.56 & 3.09 & 0.380 & 100.00 & 32 & - & - & 321 & 52 & 694 & 355 & 183 \\
\hline 2.120 & 14.27 & 11.34 & 0.180 & 8.36 & 4.74 & 1.33 & 3.20 & 0.310 & 99.99 & 53 & - & - & 317 & 25 & 467 & 334 & 177 \\
\hline 130 & 14.32 & 11.34 & 0.210 & 8.43 & 4.58 & 1.45 & 2.90 & 0.310 & 100.00 & 56 & - & - & 309 & 0 & 50 & 339 & 182 \\
\hline 2.110 & 14.36 & 11.64 & 0.190 & 8.37 & 4.46 & 1.32 & 3.03 & 0.310 & 99.99 & 84 & 39 & 34 & 343 & 34 & 503 & 351 & 177 \\
\hline 2.070 & 14.41 & 11.70 & 0.190 & 7.54 & 4.08 & 1.30 & 3.28 & 0.360 & 100.00 & 16 & & & 342 & 21 & 617 & 360 & 183 \\
\hline 852 & 6.55 & 1 & 0.17 & 9.3 & $6 . c$ & 1. & 2. & 0.242 & & 13 & 12 & U & 25 & 24 & 21 & 527 & 134 \\
\hline 2.066 & 16.17 & 11.64 & 0.171 & 9.53 & 6.45 & 0.71 & 3.00 & 0.264 & 100.00 & 117 & 128 & 33 & 268 & 14 & 24 & 391 & 149 \\
\hline 2.221 & 16.00 & 12.48 & 0.203 & 7.97 & 5.63 & 0.45 & 4.70 & 0.267 & 100.00 & 95 & 137 & 30 & 302 & 8 & 16 & 378 & 151 \\
\hline 2.405 & 16.59 & 12.57 & 0.175 & 8.75 & 6.38 & 0.72 & 2.79 & 0.309 & 100.00 & 121 & 135 & 30 & 268 & 12 & 26 & 354 & 164 \\
\hline 2.703 & 14.15 & 13.37 & 0.206 & 9.14 & 4. & 0. & 3.19 & 0.378 & 100.00 & 41 & 111 & 3 & 375 & 2 & 371 & 321 & 198 \\
\hline 2.226 & 16.38 & 11.06 & 0.163 & 9.11 & 5.48 & 0.94 & 3.04 & 0.287 & 100.00 & 43 & 81 & 31 & 259 & 25 & 321 & 368 & 165 \\
\hline 2.777 & 13.33 & 13.8 & 0.235 & 8.05 & 4.0 & 1.1 & 3.25 & 0.480 & 100.00 & 14 & 25 & & 39 & 30 & 447 & 315 & 228 \\
\hline 1.921 & 16.53 & 11.48 & 0.177 & 9.36 & 6.80 & 2.35 & 1.90 & 0.246 & 100.00 & 110 & 120 & 29 & 276 & 65 & 189 & 324 & 135 \\
\hline
\end{tabular}


Table A.1. (contd)

Wanapum Basalt Formation, Average Flow Compositions: Analyzed at Univ. Massachusetts-Amherst

Unit Ident.

Priest Rapids, basalt of Lolo Priest Rapids, basalt of Rosal Roza, unit IV

Roza, unit II-B

Roza, unit II-A

Roza, unit I

Shumaker Creek

Fr. Spr., basalt of Lyons Ferry

Fr. Spr., basalt of Sentinel Gap

Fr. Spr, basalt of Ginkgo

Fr. Spr., basalt of Palouse Falls

Eckler Mtn., basalt of Dodge

Eckler Mtn., basalt of Rob. Mtn.
MAJOR OXIDES (weight per cent)

\begin{tabular}{lllllllll}
- & - & - & - & - & - & - & - & - \\
\hline
\end{tabular}

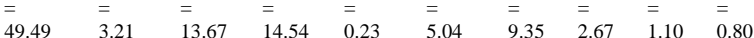

$\begin{array}{llllllllll}49.66 & 3.61 & 12.77 & 14.54 & 0.23 & 5.04 & 9.35 & 2.67 & 1.10 & 0.80 \\ & 3.24 & 4.31 & 8.48 & 2.73 & 1.27 & 0.80\end{array}$

$\begin{array}{llllllllll}50.40 & 3.08 & 13.61 & 14.84 & 0.22 & 4.31 & 8.48 & 2.73 & 1.27 & 0.80 \\ 5 & 13.42 & 8.81 & 2.62 & 1.27 & 0.65\end{array}$

$\begin{array}{llllllllll}50.15 & 3.08 & 13.54 & 15.20 & 0.22 & 4.53 & 8.71 & 2.74 & 1.17 & 0.64 \\ 50.19 & 3.08 & 13.60 & 15.10 & 0.22 & 4.57 & 8.73 & 2.72 & 1.20 & 0.65\end{array}$

$\begin{array}{llllll}4.49 & 8.60 & 2.76 & 1.29 & 0.68\end{array}$

$\begin{array}{llllllllll}50.17 & 3.19 & 13.19 & 15.54 & 0.23 & 4.39 & 8.45 & 2.80 & 1.33 & 0.71 \\ 54.07 & 2.46 & 13.24 & 14.01 & 0.27 & 2.92 & 6.80 & 3.34 & 1.97 & 0.97\end{array}$

$\begin{array}{llllllllll}51.00 & 3.11 & 13.06 & 15.48 & 0.22 & 4.18 & 8.40 & 2.88 & 1.26 & 0.59\end{array}$

$\begin{array}{lllllllllll}51.01 & 3.04 & 13.05 & 15.51 & 0.22 & 4.07 & 8.18 & 2.91 & 1.34 & 0.63\end{array}$

$\begin{array}{llllllllll}51.04 & 2.89 & 13.18 & 15.14 & 0.23 & 4.36 & 8.34 & 2.97 & 1.30 & 0.57 \\ 50.60 & 3.10 & 13.06 & 15.67 & 0.23 & 4.16 & 8.25 & 2.99 & 1.25 & 0.63\end{array}$

$\begin{array}{lllllllllll}50.83 & 3.10 & 13.04 & 15.64 & 0.24 & 3.96 & 8.22 & 2.91 & 1.29 & 0.630\end{array}$

$\begin{array}{lllllllllll}50.89 & 3.08 & 13.01 & 15.49 & 0.24 & 4.35 & 8.37 & 2.92 & 1.17 & 0.55\end{array}$

$\begin{array}{lllllllllll}51.18 & 1.39 & 14.73 & 12.14 & 0.21 & 6.30 & 10.61 & 2.82 & 0.45 & 0.32\end{array}$

$\begin{array}{llllllllll}48.92 & 0.96 & 16.83 & 11.08 & 0.19 & 8.10 & 11.20 & 2.47 & 0.24 & 0.16\end{array}$
TRACE ELEMENTS (ppm)

$\begin{array}{lllllllllllll}\mathrm{Ni} & \mathrm{Cr} & \text { Sc } & \text { V } & \text { Rb } & \text { Ba } & \text { Sr } & \text { Zr } & \text { Nb } & \text { Y } & \text { Zn } & \text { Ce } & \text { La }\end{array}$

$\begin{array}{lllllllllllll}= & = & = & = & = & = & = & = & = & = & = & = & = \\ 56 & 91 & - & 323 & 25.2 & 581 & 305 & 202 & 15.8 & 43.5 & 153 & 56 & 27\end{array}$

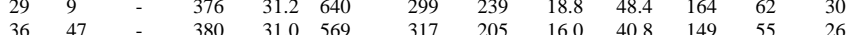

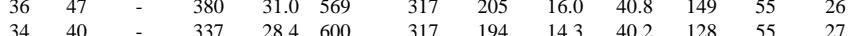

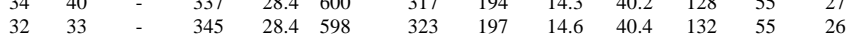

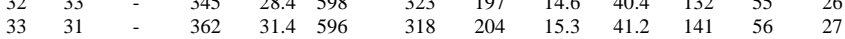

$\begin{array}{lllllllllllll}31 & 22 & - & 373 & 32.2 & 624 & 315 & 209 & 15.7 & 42.7 & 141 & 58 & 26\end{array}$

$\begin{array}{lllllllllllll}13 & 2 & - & 150 & 46.9 & 1126 & 347 & 278 & 20.1 & 59.0 & 160 & 83 & 38 \\ 28 & 16 & - & 354 & 30.2 & 627 & 326 & 206 & 14.8 & 41.5 & 133 & 54 & 24\end{array}$

$\begin{array}{lllllllllllll}28 & 16 & - & 354 & 30.2 & 627 & 326 & 206 & 14.8 & 41.5 & 133 & 54 & 24 \\ 21 & 15 & - & 374 & 340 & 640 & 322 & 208 & 15 . & 41.7 & 144 & 57 & 25\end{array}$

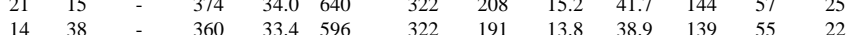

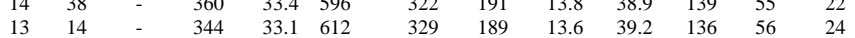

$\begin{array}{lllllllllllll}9 & 15 & - & 336 & 34.0 & 594 & 331 & 194 & 14.3 & 39.9 & 147 & 55 & 24\end{array}$

$\begin{array}{lllllllllllll}29 & 31 & - & 318 & 28.4 & 608 & 306 & 170 & 11.7 & 39.0 & 132 & 48 & 24\end{array}$

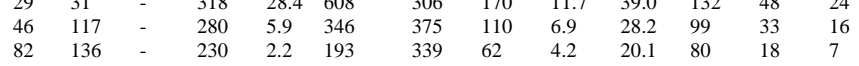

